\title{
Metrology Measurement Capabilities
}

Federal Manufacturing \& Technologies

Dr. Glen E. Gronniger

KCP-613-8382

Distributed October 2007

Final Report

Approved for public release; distribution is unlimited.

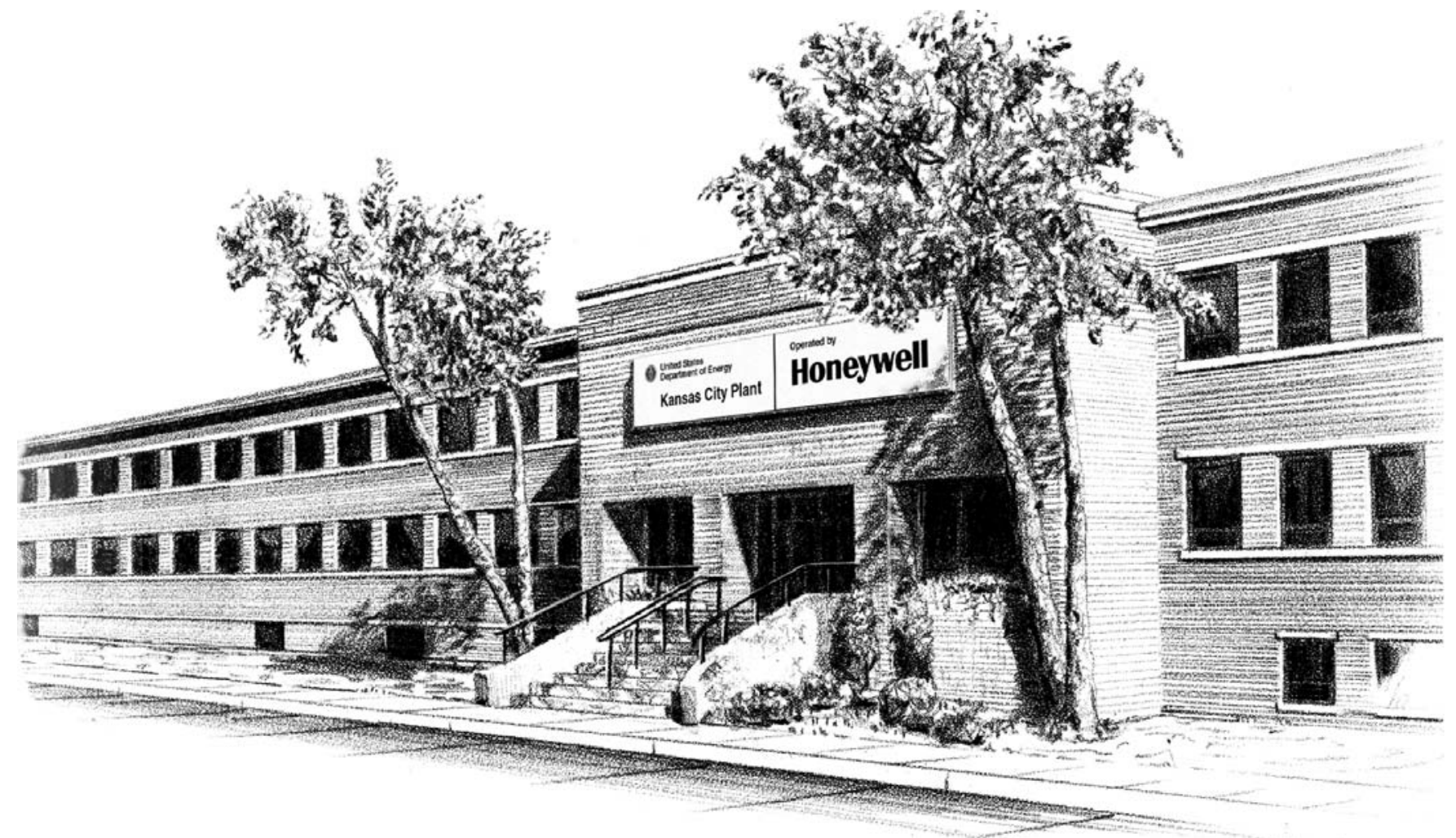

Prepared under prime contract DE-ACO4-01AL66850 for the

United States Department of Energy 


\section{DISCLAIMER}

This report was prepared as an account of work sponsored by an agency of the United States Government. Neither the United States Government nor any agency thereof, nor any of their employees, makes any warranty, express or implied, or assumes any legal liability or responsibility for the accuracy, completeness, or usefulness of any information, apparatus, product, or process disclosed, or represents that its use would not infringe privately owned rights. Reference herein to any specific commercial product, process or service by trade names, trademark, manufacturer, or otherwise, does not necessarily constitute or imply its endorsement, recommendation or favoring by the United States Government or any agency thereof. The views and opinions of authors expressed herein do not necessarily state or reflect those of the United States Government or any agency thereof.

All data prepared, analyzed and presented has been developed in a specific context of work and was prepared for internal evaluation and use pursuant to that work authorized under the reference contract. Reference herein to any specific commercial product, process or service by trade name, trademark, manufacturer, or otherwise, does not necessarily constitute or imply its endorsement, recommendation or favoring by the United States Government, any agency thereof or Honeywell Federal Manufacturing \& Technologies, LLC.

Printed in the United States of America.

This report has been reproduced from the best available copy.

Available to DOE and DOE contractors from the Office of Scientific and Technical Information, P.O. Box 62, Oak Ridge, Tennessee 37831; prices available from (865) 576-8401, FTS 626-8401.

Available to the public from the National Technical Information Service, U.S. Department of Commerce, 5285 Port Royal, Rd., Springfield, Virginia 22161, (703) 487-4650.

A prime contractor with the United States Department of Energy under Contract Number DE-AC04-O1AL66850

\author{
Honeywell Federal Manufacturing \& Technologies \\ P.O. Box 419159 \\ Kansas City, Missouri, 64141-6159
}




\section{Honeywell}

KCP-613-8382

Distribution Category UC-706

Approved for public release; distribution is unlimited.

\section{METROLOGY MEASUREMENT CAPABILITIES}

Dr. Glen E. Gronniger

Distributed October 2007

Final Report 


\section{Contents}

Section Page

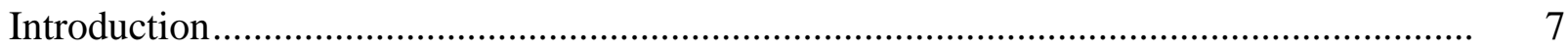

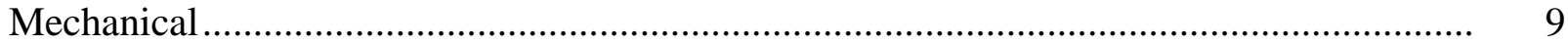

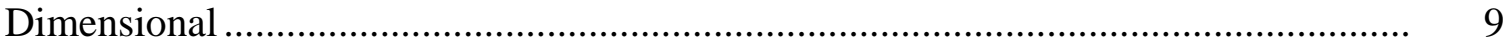

Length and Coordinate Measurement ......................................................... 9

Gage Block Measurement....................................................................... 9

Roundness Measurement ............................................................................. 9

Flatness Measurement............................................................................ 10

Angle Measurement ...................................................................................... 11

Surface Finish Measurement........................................................................ 11

Mass, Force, and Torque and Volumetric.................................................................. 16

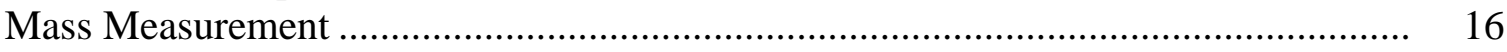

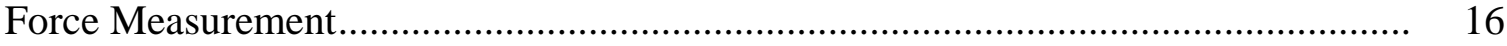

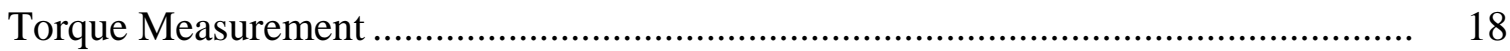

Laboratory Glassware Volume ........................................................................ 19

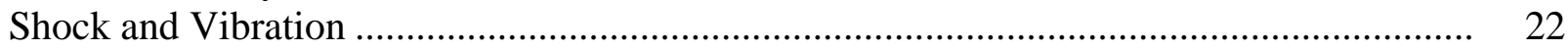

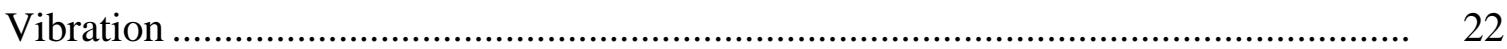

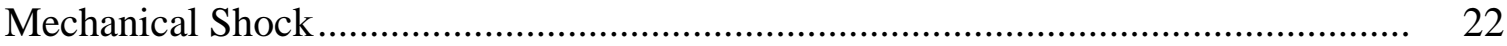

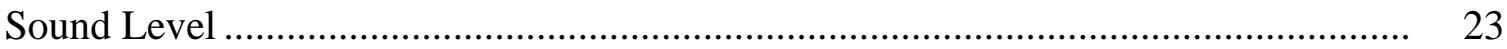

Environmental, Gas, Liquid .................................................................................... 26

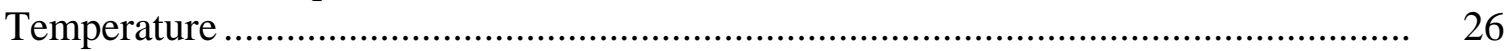

SPRT Calibration Using a Fixed Point Temperature Cell ............................... 26

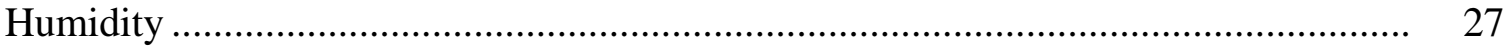

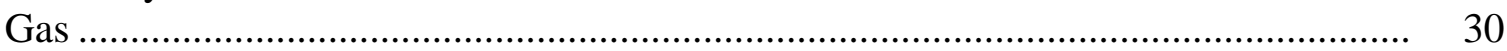

Pressure .............................................................................. $\quad 30$

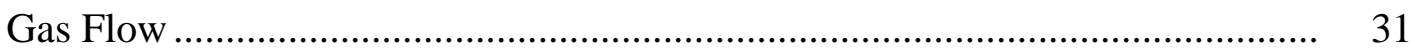

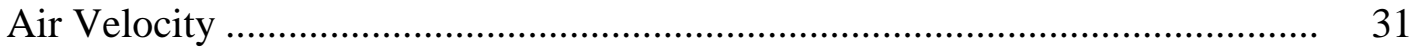

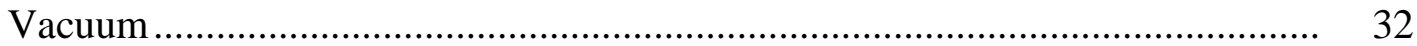

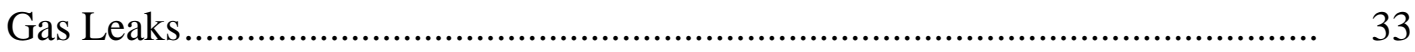

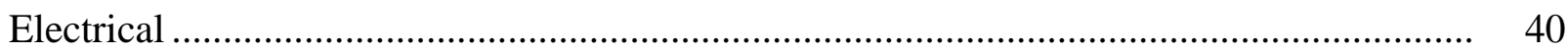

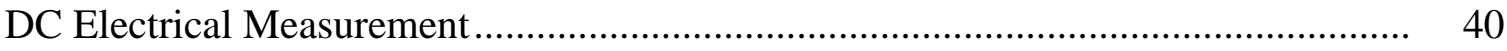

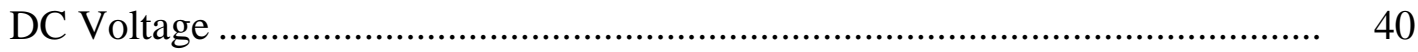

DC Current ............................................................................................. 40

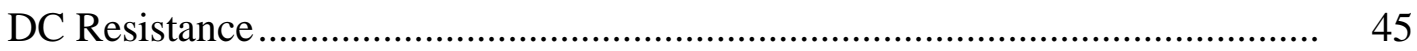

AC Electrical Measurement............................................................................... 47

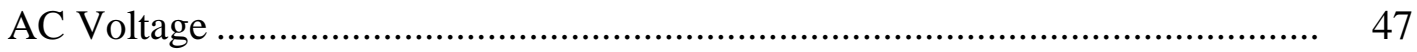

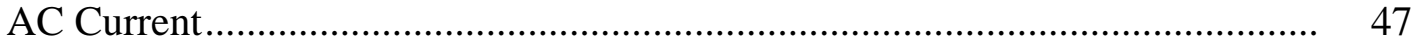

Capacitance and Inductance.................................................................... 48

Frequency and Time .............................................................................. 48

RF/Microwave Measurements ........................................................................ 56

Air Lines ................................................................................... 56

Attenuators and Terminations................................................................. 56

Network Analyzers and Attenuation Systems ............................................ 56

Noise Source .......................................................................................... 56 


\section{Contents (cont'd)}

Section

Page

Thermistor Mounts......................................................................................... 57

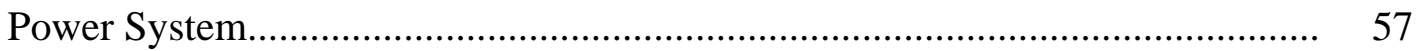

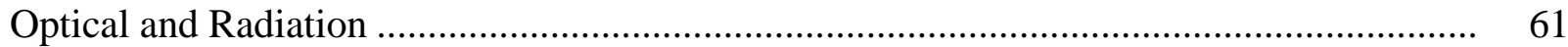

Optical Radiometric Measurement ................................................................... 61

Optical Photometric Measurement ........................................................................ 61

\section{Measurement Capability Tables}

Dimensional Measurement Capability......................................................................... 10

Angle, Roughness, and Flatness Measurement Capability ............................................. 13

Mass, Force, and Torque Measurement Capability ..................................................... 18

Laboratory Glassware Volumetric Measurement Capability ............................................ 19

Vibration, Acceleration, Shock, Sound Level Measurement Capability ............................ 23

Temperature, Humidity Measurement Capability ....................................................... 27

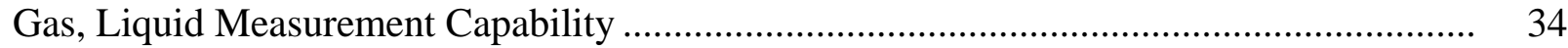

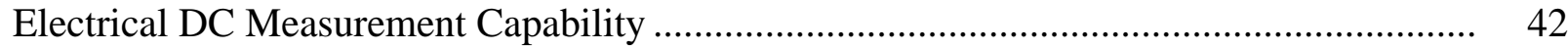

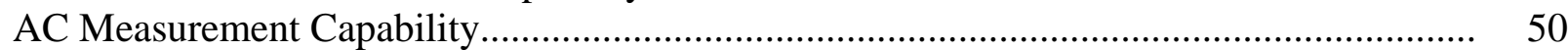

Electrical Radio Frequency/Microwave Measurement Capability .................................... 58

Optical Measurement Capability .................................................................................. 62

\section{Measurement Standards Tables}

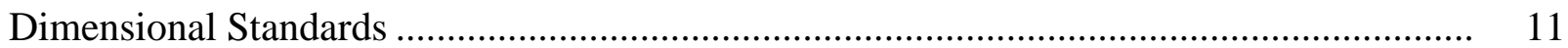

Angle, Roughness, and Flatness Standards............................................................... 15

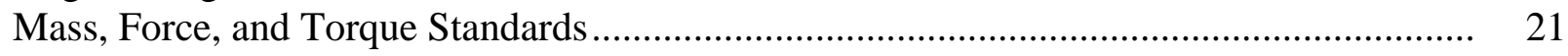

Vibration, Acceleration, and Shock Standards ........................................................... 25

Temperature, Humidity Standards ..................................................................... 29

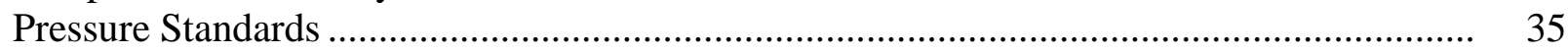

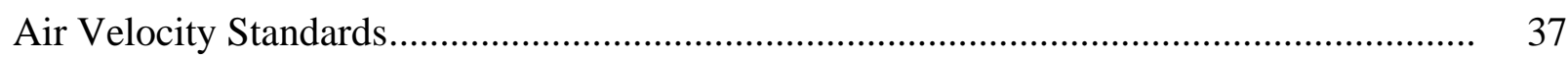

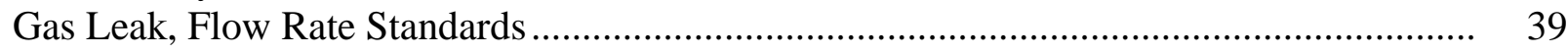

DC Current and Voltage Standards.......................................................................... 44

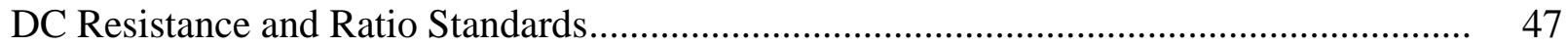

AC Current, Voltage, and Ratio Standards ............................................................ 51

Inductance, Capacitance, and AC Resistance Standards ............................................ 54

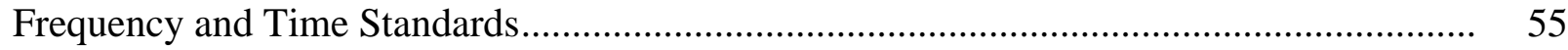

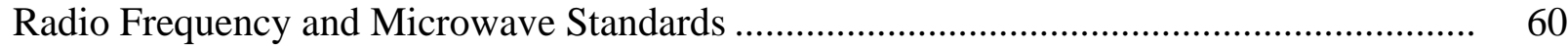

Optical Radiometric Measurement Standards ............................................................ 64 


\section{Illustrations}

Shelton CMM With CMM Calibration Artifact .... Page 9

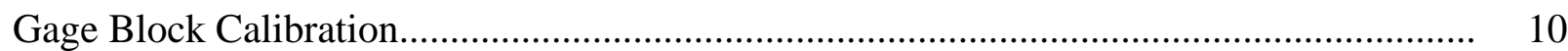

Dimensional Calibration Traceability............................................................................ 13

Angle, Roughness, Flatness Traceability ......................................................................... 14

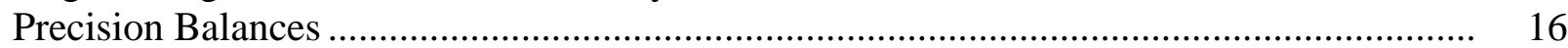

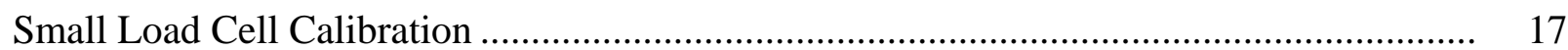

Dead Weight Force Calibration ........................................................................................ 17

Mass, Force, and Torque Traceability .............................................................................. 20

Vibration Calibration System with Environmental Capability .............................................. 22

Velocity Change Shock Pulse Generator ................................................................................ 23

Vibration, Shock, Sound Level Traceability........................................................................ 24

Automated Temperature Calibration ................................................................................ 26

Humidity Calibration Using the Two-Pressure Method ........................................................ 27

Temperature, Humidity Calibration Traceability .................................................................. 28

30,000 psig Gas Pressure Calibration .......................................................................... $\quad 30$

Air Velocity Calibration ........................................................................................ 31

Vacuum Gage Calibration............................................................................................. 32

Standard Leak Calibration .............................................................................................. 33

Pressure Calibration Using Controlled Clearance Dead-Weight Piston Gage ...................... 34

Pressure Calibration Traceability ........................................................................................ 35

Air Velocity Calibration Traceability ………………………………………………...... 36

Gas Leak, Flow Rate Calibration Traceability ………….................................................. 38

DC Voltage Inter-comparison..................................................................................... 40

Automated Digital Multimeter Calibration.................................................................... 41

DC Current, Voltage, and Ratio Traceability …………….................................................. 43

Automated Resistance Measuring System........................................................................... 45

DC Resistance Traceability..................................................................................... 46

Impedance Calibration .......................................................................................... 48

Computer-Controlled Counter Calibration .......................................................................... 49

AC Current, Voltage, and Ratio Traceability ……………................................................. 51

Inductance and Capacitance Traceability …………………............................................... 53

Frequency and Time Traceability ..................................................................................... 55

Attenuator Calibration Using an Automatic Network Analyzer............................................ 56

Power Meter Calibration.......................................................................................... 5

Radio Frequency and Microwave Traceability .................................................................. 59

Laser Wavelength Calibration ............................................................................................ 61

Optical Traceability (Radiometric) ..................................................................................... 63

Nd:YAG Laser Power Meter Calibration ....................................................................... 64 
This Page Intentionally Left Blank 


\section{Introduction}

This document contains descriptions of Federal Manufacturing \& Technologies (FM\&T) Metrology capabilities, traceability flow charts, and the measurement uncertainty of each measurement capability.

Metrology provides NIST traceable precision measurements or equipment calibration for a wide variety of parameters, ranges, and state-of-the-art uncertainties. Metrology laboratories conform to the requirements of the Department of Energy Development and Production Manual Chapter 13.2, ANSI/ISO/IEC ANSI/ISO/IEC 17025:2005, and ANSI/NCSL Z540-1.

FM\&T Metrology laboratories are accredited by NVLAP for the parameters, ranges, and uncertainties listed in the specific scope of accreditation under NVLAP Lab code 200108-0. See the Internet at http://ts.nist.gov/Standards/scopes/2001080.pdf. These parameters are summarized on the following page.

The Honeywell Federal Manufacturing \& Technologies (FM\&T) Metrology Department has developed measurement technology and calibration capability in four major fields of measurement:

- Mechanical

- Environmental, Gas, Liquid

- Electrical (DC, AC, RF/Microwave)

- Optical and Radiation

Metrology Engineering provides the expertise to develop measurement capabilities for virtually any type of measurement in the fields listed above.

A strong audit function has been developed to provide a means to evaluate the calibration programs of our suppliers and internal calibration organizations. Evaluation includes measurement audits and technical surveys. 
Measurement and Calibration Capabilities

*NVLAP Accredited in these parameters

\author{
Dimensional \\ Length * \\ Coordinate Measuring Machines * \\ Coordinate Measurement * \\ Angle Measurement * \\ Gage Blocks * \\ Glass Scales * \\ Internal/External Diameters * \\ Roundness * \\ Spherical Diameter * \\ Flatness Measurement * \\ Thread Wires * \\ Surface Finish Measurement \\ Angle, Roughness, and Flatness \\ Angle * \\ Surface Roughness \\ Optical Surface Flatness * \\ Surface Plate Flatness * \\ Mass, Force and Torque \\ Mass * \\ Force * \\ Torque \\ Vibration, Acceleration, Shock, Sound Level \\ Vibration * \\ Shock * \\ Sound Level \\ Environmental, Gas, Liquid \\ Temperature * \\ Fixed Point Temperature * \\ Humidity \\ Pressure * \\ Gas Flow \\ Leak Rate * \\ Air Velocity*
}

\author{
Electrical AC/DC \\ AC/DC Voltage * \\ AC/DC Current \\ AC/DC Resistance * \\ Capacitance, Inductance * \\ Frequency, Time * \\ DC Magnetic Field Density
}

Electrical RF/Microwave

Attenuation *

RF Power *

RF Reflection Coefficient *

Network Analyzers

Specific Gravity, Laboratory Glassware

Volume

Specific Gravity

Laboratory Glassware Volume

Burets

Volumetric Pipets

Measuring Pipets

Volumetric Flasks

Graduated Cylinders

Optical Radiometric, Photometric

Optical Transmittance

Optical Spectral Response

Laser Average Power

Laser Peak Power

LED Power

Ultraviolet Irradiance

Illuminance

Monochrometers

X-Ray Film Density

Luminous Intensity

HeNe Laser Frequency, Wavelength * 


\section{Mechanical}

\section{Dimensional}

\section{Length and Coordinate Measurement}

General length and coordinate standard measurements are made on a custom built coordinate measuring machine (CMM). The CMM is a fixed bride, all-granite machine using air bearings for all guide ways. The CMM uses laser interferometers to measure displacement. The probing system is an active analog scanning type probe. The CMM has also been fitted with a video microscope system to perform measurements of glass grid plates and line scales. Uncertainties are listed in the accompanying tables.

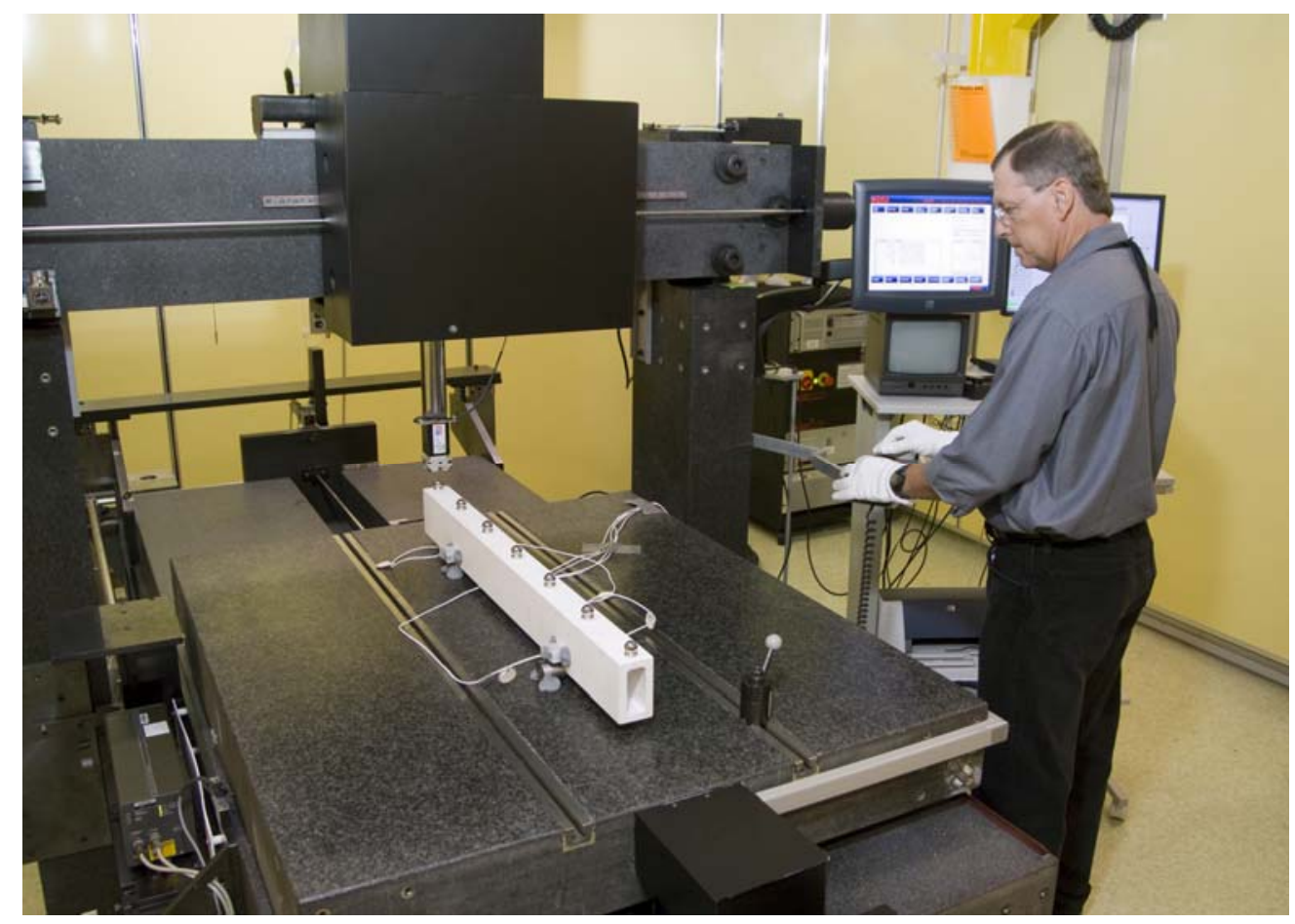

Shelton CMM with CMM Calibration Artifact

\section{Gage Block Measurement}

Gage blocks are compared to blocks certified by the Primary Standards Laboratory (PSL) using a gage block comparator.

\section{Roundness Measurement}

Roundness measurements are made using a roundness machine with an air-bearing spindle.

Spindle error measurements are made using a reversal technique that separates spindle error from roundness error. 


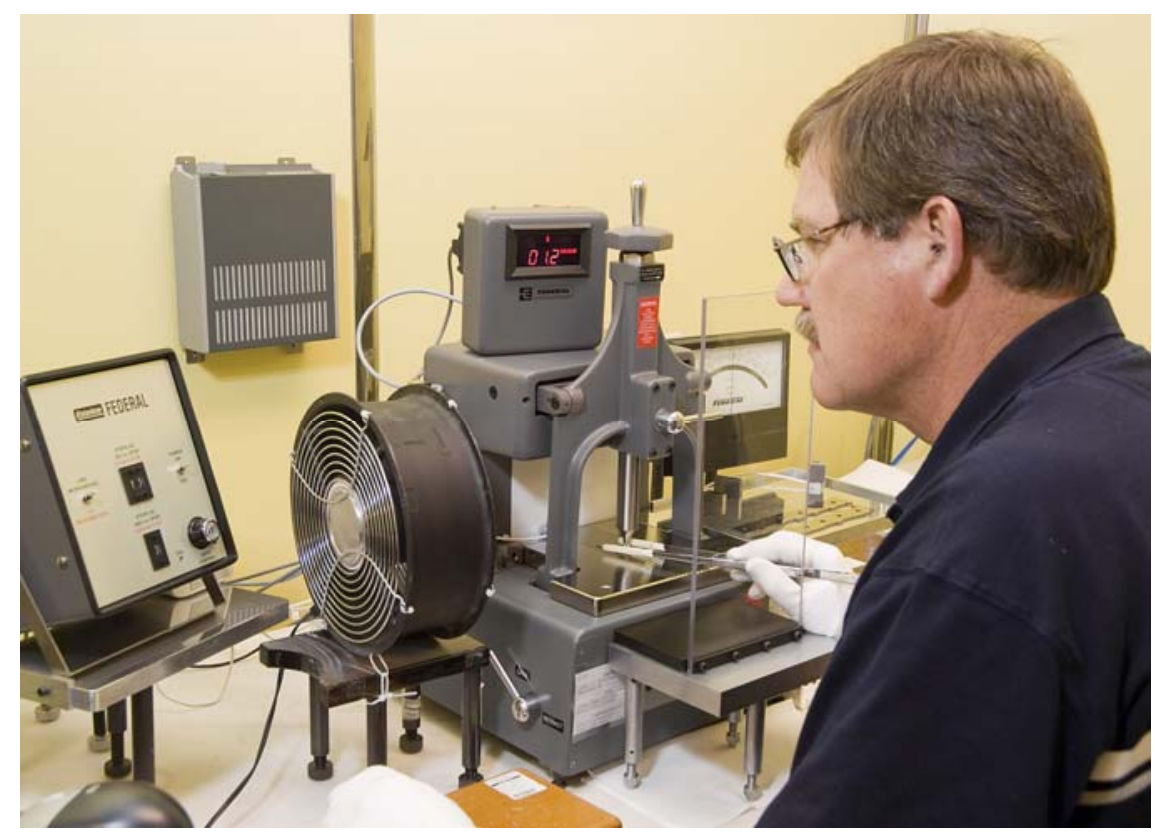

\section{Gage Block Calibration}

\section{$\underline{\text { Flatness Measurement }}$}

Flatness of small surfaces is measured directly using an optical flat or an optical interferometer. Reference optical flats are calibrated using the three-flat method and a polychromatic fringe viewer. Surface plate flatness is measured using an autocollimator and mirror(s). The flatness of the surface plate is determined using both the Moody method and a three-dimensional least squares technique.

Dimensional Measurement Capability

\begin{tabular}{|l|l|l|}
\hline Type & Range & Measuring Uncertainty $( \pm$ ) $\mathbf{k = 2}$ \\
\hline Gage Blocks & To 4 in. & $2.6 \mu \mathrm{in} .+0.3 \mathrm{ppm}$ \\
\hline & $>4$ to $20 \mathrm{in.}$ & $6.7 \mu \mathrm{in} .+0.3 \mathrm{ppm}$ \\
\hline Coordinate Measurement $*$ & Axial & $10 \mu \mathrm{in}+0.3 \mathrm{ppm}$ \\
\hline & Planar ** & $30 \mu \mathrm{in} .+0.5 \mathrm{ppm}$ \\
\hline 1-D Ball Plates & To 48 in. & $20 \mu \mathrm{in}+0.7 \mathrm{ppm}$. \\
\hline 2-D Ball Plates & 36 in. by 36 in. & $20 \mu \mathrm{in}+0.7 \mathrm{ppm}$. \\
\hline Step Gages & To 24 in. & $15 \mu \mathrm{in}+0.6 \mathrm{ppm}$. \\
\hline Internal Diameters & 0.04 to 1 in. & $10 \mu \mathrm{in}$ \\
& 1 to 14 in. & Determined by Test \\
\hline Single Axis Glass Line Scales & 0 to 16 in. & $15 \mu \mathrm{in}+0.5 \mathrm{ppm}$. \\
\hline
\end{tabular}




\section{Dimensional Measurement Capability}

\begin{tabular}{|l|l|l|}
\hline Type & Range & Measuring Uncertainty $(\mathbf{\pm}) \mathbf{k = 2}$ \\
\hline Spherical Diameter & 0 to 1 in. & $8.3 \mu \mathrm{in}$. \\
& 1 to 2 in. & $16 \mu \mathrm{in}$. \\
\hline Cylindrical Plug Gages & 0 to 1 in. & $6.2 \mu \mathrm{in}$. \\
\hline Squares & To 24 in. by 36 in. & $30 \mu \mathrm{in}$. \\
\hline Straight Edges & To 48 in. & $5 \mu$ in. \\
\hline Roundness & To 18 -in. diameter & $2 \mu$ in. \\
\hline Thread Wires & All standard pitches & $8 \mu$ in. \\
\hline * Maximum range of length-coordinate measurement is $\mathrm{x}=48$ in., y $=36$ in., and z = 12 in. \\
** Certain artifacts, such as ball plates, can be designed in such a way to allow the use of a single-axis calibration \\
technique. The technique requires the balls to be located in an orderly array with one ball located in the center. \\
Artifacts of this design can be certified to $\pm(20 \mu$ in +0.7 ppm).
\end{tabular}

\section{Angle Measurement}

Small angles are measured using an autocollimator. The autocollimator is calibrated using a small-angle generator consisting of a pivot arm of known length and a set of certified gage blocks. Large angles are measured using an autocollimator, a rotary table, an optical polygon, and angle gage blocks.

\section{$\underline{\text { Surface Finish Measurement }}$}

Surface finish standards are measured using a profile-type surface finish analyzer. The surface finish analyzer is calibrated using a lever arm calibrator and roughness standards calibrated by NIST.

\section{Dimensional Standards}

\begin{tabular}{lllll}
\hline Code & Description & Manufacturer & Range & Uncertainty $( \pm)(k=2)$ \\
\hline D1 & Standard Gage & Do All & To 4 in. & $1.53 \mu \mathrm{in} .+0.7 \mathrm{ppm}$ \\
& Blocks & Pratt \& Whitney & 5 to $20 \mathrm{in}$. & $0.7 \mu \mathrm{in} .+5.7 \mathrm{ppm}$ \\
D2 & Gage Block & Link & 0 to $2 \mathrm{in}$. & $3 \mu \mathrm{in}$. \\
& Comparators & Federal & 0 to $4 \mathrm{in}$. & $3 \mu \mathrm{in}$. \\
& & Federal & 5 to $20 \mathrm{in}$. & $3 \mu \mathrm{in}$. \\
D3 & Transfer Standard & Do All & To $4 \mathrm{in}$. & $2.6 \mu \mathrm{in} .+0.3 \mathrm{ppm}$ \\
& Gage Blocks & Pratt \& Whitney & 5 to $20 \mathrm{in}$. & $6.7 \mu \mathrm{in} .+0.3 \mathrm{ppm}$
\end{tabular}




\section{Dimensional Standards}

\begin{tabular}{|c|c|c|c|c|}
\hline Code & Description & Manufacturer & Range & Uncertainty $( \pm)(k=2)$ \\
\hline D4 & $\begin{array}{l}\text { Lever Arm } \\
\text { Calibrator }\end{array}$ & FM\&T Metrology & 0 to $0.0002 \mathrm{in.}$ & $0.25 \mu$ in. $+0.5 \%$ of trave \\
\hline D5 & Measuring Machine & Pratt \& Whitney & 0 to $14 \mathrm{in.}$ & $3 \mu \mathrm{in} .+2$ ppm \\
\hline D6 & $\begin{array}{l}\text { Standard Gauging } \\
\text { Balls }\end{array}$ & AA Industries & $1 / 16$ to $1 \mathrm{in}$. & $6 \mu$ in. \\
\hline D7 & $\begin{array}{l}\text { Interference } \\
\text { Microscope }\end{array}$ & Zeiss & 0 to $0.01 \mathrm{in.}$ & $1 \mu \mathrm{in}$. \\
\hline D8 & Laser Interferometer & Hewlett-Packard & N/A & $0.05 \mathrm{ppm}$ \\
\hline D9 & Measuring Machine & Pratt \& Whitney & $1 \mathrm{in.}$ & $10 \mu$ in. \\
\hline D10 & Measuring Machine & FM\&T Metrology & 0 to 2 in. & $8 \mu \mathrm{in}$. \\
\hline D11 & Standard Plug Gages & s Lincoln & 0.050 to $1 \mathrm{in.}$ & $4.6 \mu$ in. \\
\hline D12 & $\begin{array}{l}\text { Coordinate } \\
\text { Measuring Machine }\end{array}$ & $\begin{array}{l}\text { SIP/FM\&T } \\
\text { Metrology }\end{array}$ & 0 to 16 in & $\begin{array}{l}\text { Included in Line Scale } \\
\text { Process }\end{array}$ \\
\hline D13 & $\begin{array}{l}\text { Roundness } \\
\text { Measuring Machine }\end{array}$ & Bendix A \& M & 18-in. diameter & $2 \mu \mathrm{in}$. \\
\hline $\mathrm{D} 14 *$ & $\begin{array}{l}\text { Coordinate } \\
\text { Measuring Machine }\end{array}$ & Shelton & $\begin{array}{l}\text { Axial } \\
\text { x-y plane** }\end{array}$ & $\begin{array}{l}10 \mu \mathrm{in} .+0.3 \text { ppm } \\
30 \mu \mathrm{in} .+0.5 \mathrm{ppm}\end{array}$ \\
\hline D15 & Standard Ring Gages & sFM\&T Metrology & 0 to $1 \mathrm{in.}$ & $4.6 \mu \mathrm{in}$. \\
\hline
\end{tabular}

* Maximum range: $\mathrm{x}=48$ in., $\mathrm{y}=36$ in., $\mathrm{z}=12$ in.

** Certain artifacts, such as ball plates, can be designed in such a way to allow the use of a single-axis calibration technique. This requires the balls to be located in an orderly array with one ball located in the center. Artifacts of this design can be certified to $\pm(20 \mu \mathrm{in}+0.7 \mathrm{ppm}$. $)$. 


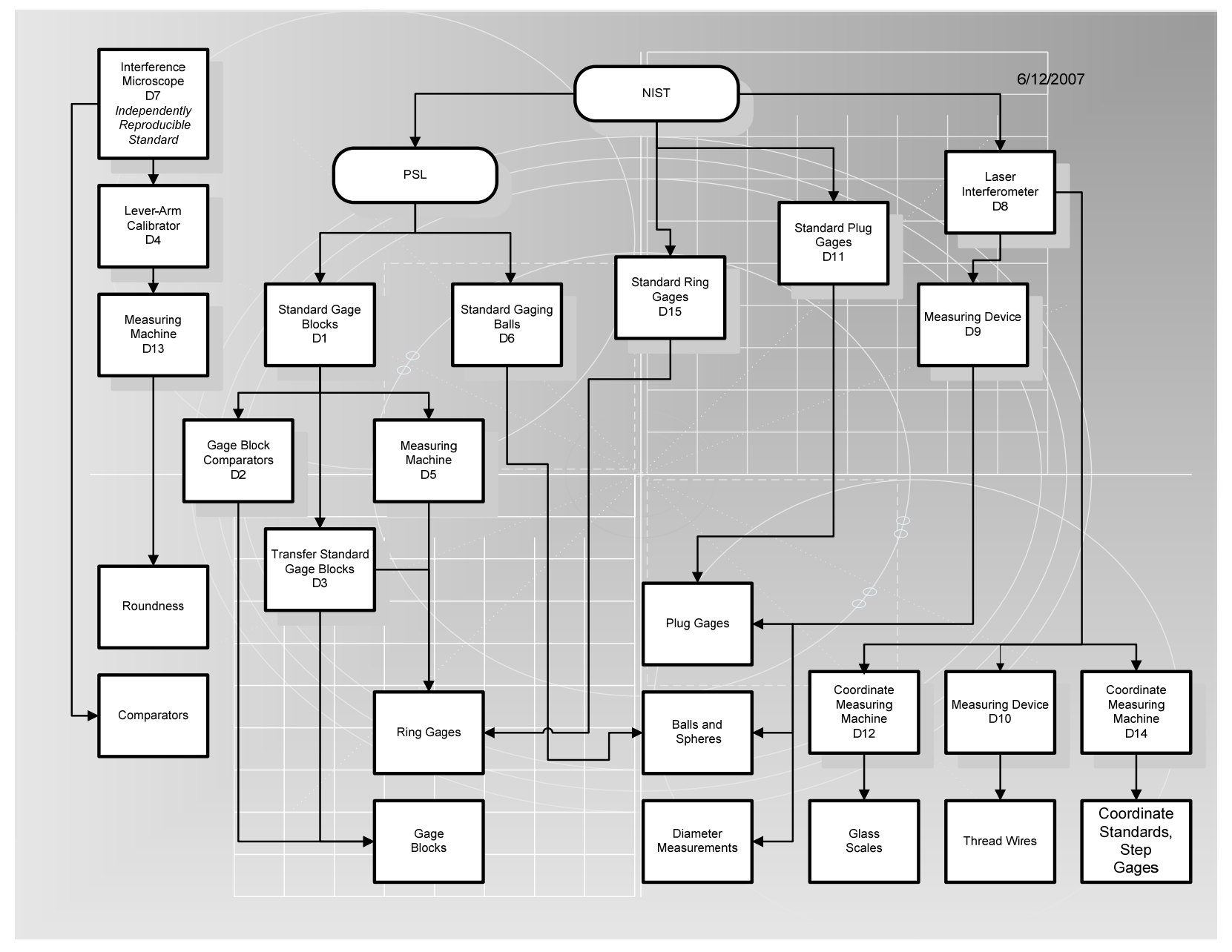

Dimensional Calibration Traceability

Angle, Roughness, and Flatness Measurement Capability

\begin{tabular}{|l|l|l|}
\hline Type & Range & Measuring Uncertainty $( \pm)(\mathrm{k}=2)$ \\
\hline Angle (Polygon/Index Table) & 0 to $360^{\circ}$ & 0.4 arc second \\
\hline Angle Blocks & To $45^{\circ}$ & 1.1 arc second \\
\hline Autocollimators & $\begin{array}{l}0 \text { to } 30 \text { arc seconds } \\
0 \text { to } 600 \text { arc seconds }\end{array}$ & $\begin{array}{l}0.10 \text { arc second } \\
0.2 \text { arc second }+0.2 \%\end{array}$ \\
\hline Surface Roughness & 0.024 in. (Peak-to-Peak) & $0.4+1.2 \%$ of Reading (in $\mu \mathrm{in} . \mathrm{Ra})$ \\
\hline Optical Surface Flatness & To 12 -in. diameter & $\begin{array}{l}1.2 \mu \text { in. (Three Flat Method) } \\
2 \mu \text { in. (Interferometer) }\end{array}$ \\
& & $4 \mu$ in. (Direct Comparison) \\
\hline Surface Plate Flatness & Up to $8 \mathrm{ft}$ Diagonal & $30 \mu$ in. $+2 \mu$ in. $/ \mathrm{ft}^{2}$ \\
\hline
\end{tabular}




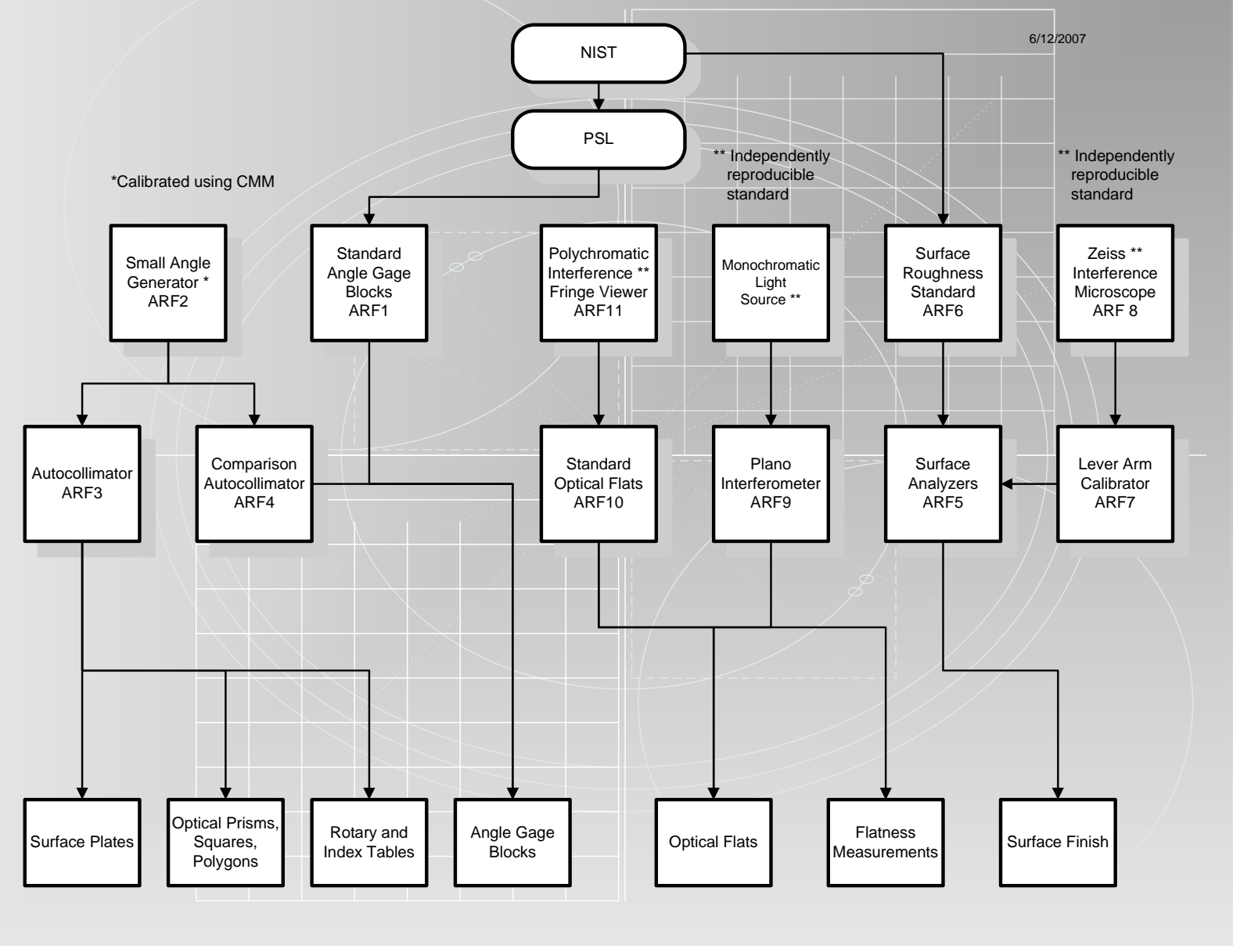

Angle, Roughness, Flatness Traceability 
Angle, Roughness, and Flatness Standards

\begin{tabular}{|c|c|c|c|c|}
\hline Code & Description & Manufacturer & Range & Uncertainty $( \pm)(k=2)$ \\
\hline ARF1 & $\begin{array}{l}\text { Standard Angle Gage } \\
\text { Blocks }\end{array}$ & Webber & $\begin{array}{l}1 \text { arc second to } 45^{\circ} \\
\text { ( } 16 \text { blocks) }\end{array}$ & 0.7 arc second \\
\hline ARF2 & Small Angle Generator & rMatrix & 10 arc minutes & 0.05 arc second \\
\hline \multirow[t]{2}{*}{ ARF3 } & Autocollimator & Moeller-Wedel & 20 arc minutes & 0.10 arc sec \\
\hline & & Nikon & 20 arc minutes & $\begin{array}{l}0.2 \text { arc second }+ \\
0.2 \% \text { of measured angle }\end{array}$ \\
\hline ARF4 & $\begin{array}{l}\text { Comparison } \\
\text { Autocollimator }\end{array}$ & Davidson & 120 arc seconds & $\begin{array}{l}0.3 \text { arc second }+ \\
0.5 \% \text { of measured angle }\end{array}$ \\
\hline ARF5 & Surface Analyzer & Federal/Metrex & $\begin{array}{l}0.024 \text { in. (peak to } \\
\text { peak) }\end{array}$ & $\begin{array}{l}(0.4+1.2 \% \text { of reading }) \mu i n . \\
\mathrm{R}_{\mathrm{a}}\end{array}$ \\
\hline ARF6 & $\begin{array}{l}\text { Surface Roughness } \\
\text { Standard }\end{array}$ & NIST & $\begin{array}{l}120 \mu \text { in. } \mathrm{R}_{\mathrm{a}} \\
39.5 \mu \mathrm{in} . \mathrm{R}_{\mathrm{a}} \\
12.7 \mu \mathrm{in} . \mathrm{R}_{\mathrm{a}}\end{array}$ & $\begin{array}{l}1.77 \mu \text { in. } \mathrm{R}_{\mathrm{a}} \\
0.59 \mu \mathrm{in} . \mathrm{R}_{\mathrm{a}} \\
0.31 \mu \mathrm{in} . \mathrm{R}_{\mathrm{a}}\end{array}$ \\
\hline ARF7 & Lever-Arm Calibrator & FM\&T Metrology & 0 to $0.0002 \mathrm{in.}$ & $0.25 \mu$ in. $+0.5 \%$ of travel \\
\hline ARF8 & $\begin{array}{l}\text { Interference } \\
\text { Microscope }\end{array}$ & Zeiss & 0 to $0.01 \mathrm{in}$. & $1 \mu \mathrm{in}$. \\
\hline ARF9 & Plano Interferometer & Davidson & 2 3/4-in. diameter & $2 \mu \mathrm{in}$. \\
\hline ARF10 & $\begin{array}{l}\text { Standard Optical Flats } \\
\text { (set of 3) }\end{array}$ & Do All & 12-in. diameter & Flat within $4 \mu \mathrm{in}$. \\
\hline ARF11 & $\begin{array}{l}\text { Polychromatic } \\
\text { Interference Fringe } \\
\text { Viewer }\end{array}$ & Strang & NA & $1 \mu$ in. \\
\hline
\end{tabular}




\section{Mass, Force, and Torque and Volumetric}

\section{Mass Measurement}

Mass measurements are made by comparison to master weights or by direct weighing using ten precision balances. The $1 \mathrm{~kg}$ master weights are calibrated by NIST and their measured value is disseminated to the rest of the master weights. Metrology also has the capability to perform extremely precise weighing on 1-2-3-5 or 1-2-2-5 decade progressions over the range of $1 \mathrm{mg}$ to $50 \mathrm{~kg}$.

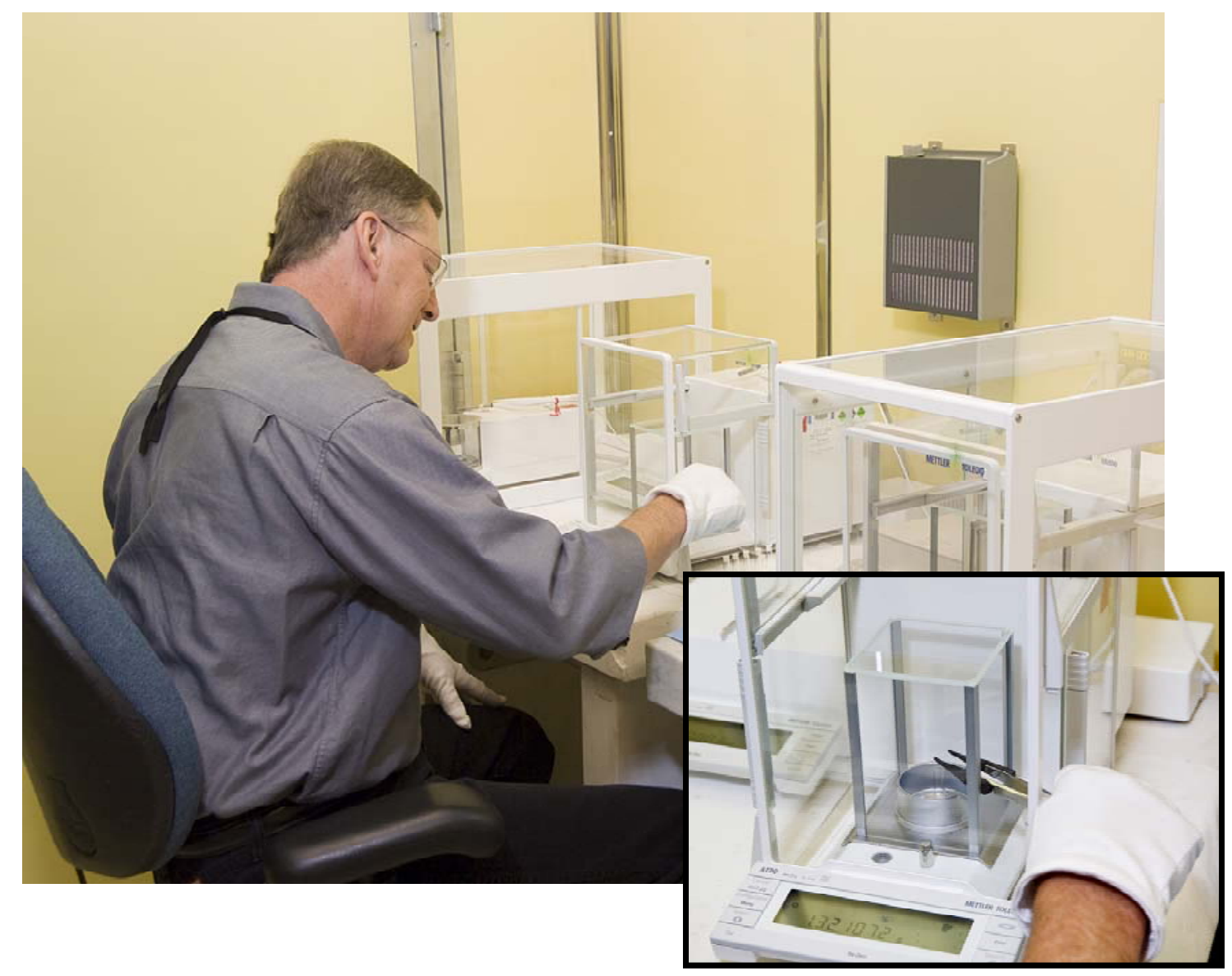

Precision Balances

\section{Force Measurement}

Force transducers up to 2400-lbf capacity are measured using weight sets or dead weight testers, which are certified in force units in our Mass lab. Larger force devices are measured by comparison to NIST-calibrated proving rings using a universal force tester. 


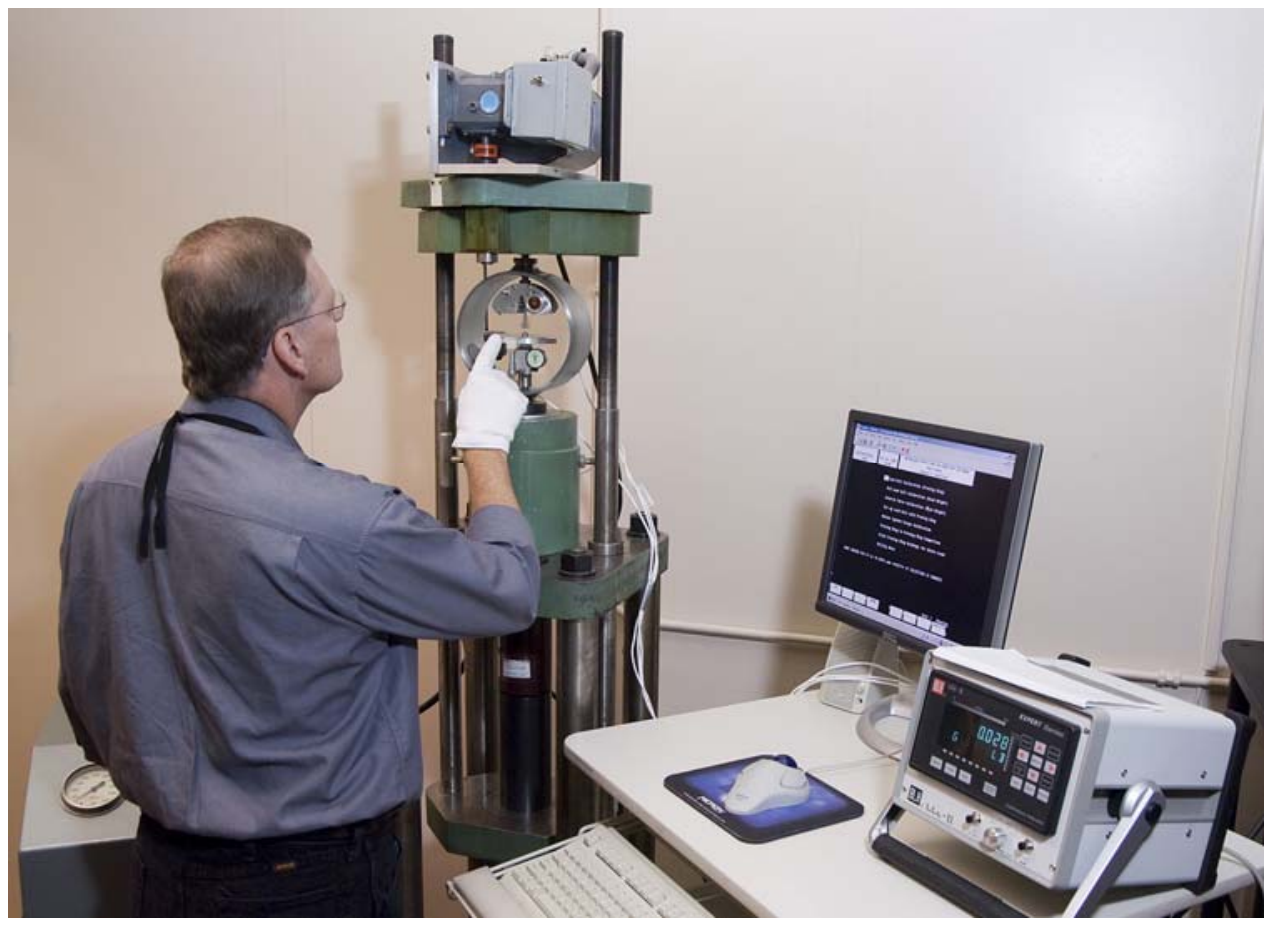

Small Load Cell Calibration

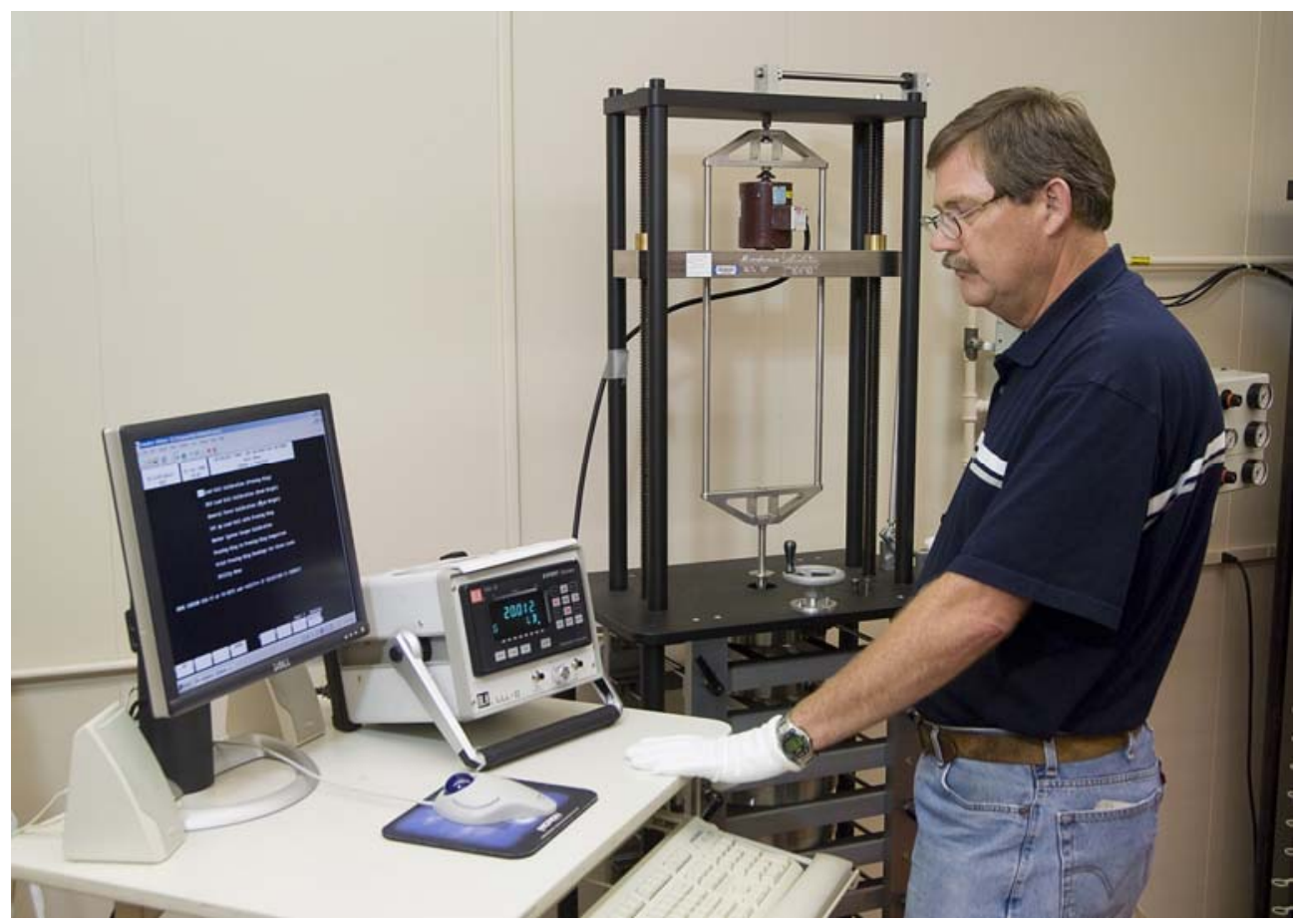

Dead Weight Force Calibration 


\section{Torque Measurement}

Torque transducers are measured using weights, which are certified in force units in our Mass lab and lever arms of known length. The lever arms are calibrated on a coordinate measuring machine using a helium-neon laser as a standard.

Mass, Force, and Torque Measurement Capability

\begin{tabular}{|c|c|c|}
\hline Type & Range & Measuring Uncertainty $( \pm)(k=2)$ \\
\hline \multirow[t]{6}{*}{ Mass (Direct Weighing) } & $1 \mathrm{mg}$ to $20 \mathrm{~g}$ & 0.01 to $0.11 \mathrm{mg}$ \\
\hline & $>20$ to $200 \mathrm{~g}$ & 0.19 to $0.7 \mathrm{mg}$ \\
\hline & $>200$ to $2000 \mathrm{~g}$ & 1.5 to $10 \mathrm{mg}$ \\
\hline & $>2000$ to $10000 \mathrm{~g}$ & 8 to $15 \mathrm{mg}$ \\
\hline & $>10000$ to $50000 \mathrm{~g}$ & 140 to $260 \mathrm{mg}$ \\
\hline & $>50000$ to $60000 \mathrm{~g}$ & $2 \mathrm{~g}$ \\
\hline \multirow[t]{6}{*}{ Mass (Direct Comparison) } & $1 \mathrm{mg}$ to $5 \mathrm{~g}$ & 0.0004 to $0.0015 \mathrm{mg}$ \\
\hline & 10 to $100 \mathrm{~g}$ & 0.026 to $0.033 \mathrm{mg}$ \\
\hline & 200 to $1000 \mathrm{~g}$ & 0.08 to $0.18 \mathrm{mg}$ \\
\hline & $2000 \mathrm{~g}$ & $0.6 \mathrm{mg}$ \\
\hline & 3000 to $10000 \mathrm{~g}$ & 1 to $27 \mathrm{mg}$ \\
\hline & 20000 to $50000 \mathrm{~g}$ & 57 to $103 \mathrm{mg}$ \\
\hline \multirow[t]{6}{*}{ Mass (Double Substitution) } & $1 \mathrm{mg}$ to $5 \mathrm{~g}$ & 0.0003 to $0.0015 \mathrm{mg}$ \\
\hline & 10 to $100 \mathrm{~g}$ & 0.004 to $0.021 \mathrm{mg}$ \\
\hline & 200 to $1000 \mathrm{~g}$ & 0.08 to $0.18 \mathrm{mg}$ \\
\hline & $2000 \mathrm{~g}$ & $0.6 \mathrm{mg}$ \\
\hline & 3000 to $10000 \mathrm{~g}$ & 1 to $27 \mathrm{mg}$ \\
\hline & 20000 to $50000 \mathrm{~g}$ & 59 to $104 \mathrm{mg}$ \\
\hline \multirow{4}{*}{$\begin{array}{l}\text { Mass (Calibration Design } \\
\text { Using 1-2-2/3-5 Decade } \\
\text { Progressions) }\end{array}$} & $1 \mathrm{mg}$ to $5 \mathrm{~g}$ & 0.0002 to $0.0026 \mathrm{mg}$ \\
\hline & 10 to $100 \mathrm{~g}$ & 0.005 to $0.047 \mathrm{mg}$ \\
\hline & 200 to $1000 \mathrm{~g}$ & 0.06 to $0.19 \mathrm{mg}$ \\
\hline & 2000 to $5000 \mathrm{~g}$ & 1 to $2 \mathrm{mg}$ \\
\hline
\end{tabular}


Mass, Force, and Torque Measurement Capability

\begin{tabular}{|lll|}
\hline Type & Range & Measuring Uncertainty $( \pm)(\mathbf{k}=\mathbf{2})$ \\
\hline Force & 0.0625 to $5 \mathrm{lbf}$ & $0.1 \%$ of reading \\
& 5 to $500 \mathrm{lbf}$ & $0.005 \%$ of reading \\
& 500 to $2400 \mathrm{lbf}$ & $0.005 \%$ of reading \\
& 750 to $3000 \mathrm{lbf}$ & $0.45 \mathrm{lbf}$ \\
& 3000 to $5000 \mathrm{lbf}$ & $0.75 \mathrm{lbf}$ \\
& 5000 to $10000 \mathrm{lbf}$ & $2.0 \mathrm{lbf}$ \\
& 10000 to $30000 \mathrm{lbf}$ & $5.0 \mathrm{lbf}$ \\
& 30000 to $100000 \mathrm{lbf}$ & $15.0 \mathrm{lbf}$ \\
\hline Torque & 1 ozf-in. to $700 \mathrm{lbf}-\mathrm{ft}$ & $0.17 \%$ of reading \\
\hline
\end{tabular}

\section{Laboratory Glassware Volume}

Laboratory glassware volume is measured by the gravimetric method using precision balances and distilled water.

\section{Laboratory Glassware Volumetric Measurement Capability}

\begin{tabular}{|c|c|c|}
\hline Type & Range & Measuring Uncertainty $( \pm)(k=2)$ \\
\hline \multicolumn{3}{|l|}{$\begin{array}{l}\text { Laboratory Glassware } \\
\text { Volume }\end{array}$} \\
\hline \multirow{4}{*}{$\begin{array}{l}\text { Burets } \\
\text { Volumetric Pipets } \\
\text { Measuring Pipets } \\
\text { Volumetric Flasks }\end{array}$} & 10 to $100 \mathrm{~mL}$ & NIST or ASTM Class A, B \\
\hline & 0.5 to $100 \mathrm{~mL}$ & NIST or ASTM Class A, B \\
\hline & 1 to $30 \mathrm{~mL}$ & NIST or ASTM Class A, B \\
\hline & 1 to $5000 \mathrm{~mL}$ & NIST Class A, B \\
\hline \multirow{2}{*}{ Graduated Cylinders } & 5 to $2000 \mathrm{~mL}$ & ASTM Class A, B \\
\hline & 5 to $2000 \mathrm{~mL}$ & NIST or ASTM Class A, B \\
\hline
\end{tabular}




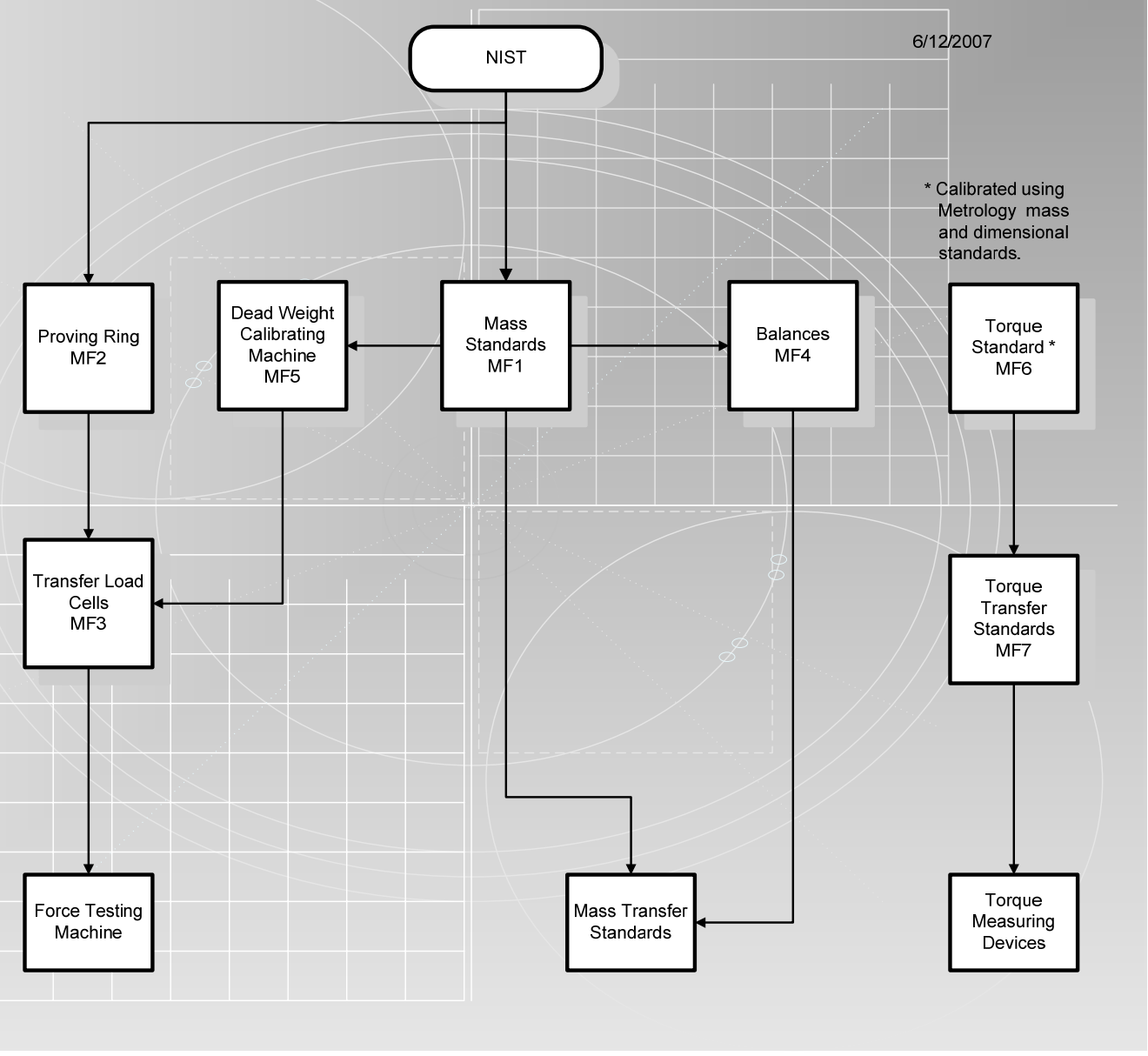

Mass, Force, and Torque Traceability 
Mass, Force, and Torque Standards

\begin{tabular}{|c|c|c|c|c|}
\hline Code & Description & Manufacturer & Range & Uncertainty $(\unlhd)(k=2)$ \\
\hline \multirow[t]{4}{*}{ MF1 } & \multirow[t]{4}{*}{ Mass Standards } & Troemner, & $1 \mathrm{mg}$ to $100 \mathrm{~g}$ & 0.000053 to $0.017 \mathrm{mg}$ \\
\hline & & Rice Lake & & \\
\hline & & Troemner & $200 \mathrm{~g}$ to $20000 \mathrm{~g}$ & 0.027 to $85 \mathrm{mg}$ \\
\hline & & Troemner & $1 \mathrm{lb}$ to $50 \mathrm{lb}$ & 2 ppm \\
\hline MF2 & Proving Rings & Morehouse & 3000 to $100,000 \mathrm{lbf}$ & 0.015 to $0.02 \%$ of range \\
\hline MF3 & Transfer Load Cells & Various & 0 to $240,000 \mathrm{lbf}$ & $0.05 \%$ F.S. $+0.1 \%$ load \\
\hline \multirow[t]{10}{*}{ MF4 } & Balances & Mettler Toledo & 0 to $6.1 \mathrm{~g}$ & Comparison \\
\hline & \multirow{9}{*}{$\begin{array}{l}\text { (uncertainties listed } \\
\text { are for direct } \\
\text { weighing) }\end{array}$} & Mettler Toledo & 0 to $22 \mathrm{~g}$ & $5 \mathrm{ppm}+0.01 \mathrm{mg}$ \\
\hline & & Mettler Toledo & 0 to $111 \mathrm{~g}$ & Comparison \\
\hline & & Mettler Toledo & 0 to $205 \mathrm{~g}$ & $3 \mathrm{ppm}+0.1 \mathrm{mg}$ \\
\hline & & Mettler Toledo & 0 to $1109 \mathrm{~g}$ & Comparison \\
\hline & & Mettler Toledo & 0 to $2300 \mathrm{~g}$ & 5 ppm \\
\hline & & Mettler Toledo & 0 to $10100 \mathrm{~g}$ & $1 \mathrm{ppm}+5 \mathrm{mg}$ \\
\hline & & Mettler Toledo & 0 to $52000 \mathrm{~g}$ & $4 \mathrm{ppm}+60 \mathrm{mg}$ \\
\hline & & Mettler & 0 to $5000 \mathrm{~g}$ & 3 ppm + 11 mg \\
\hline & & Mettler & 0 to $60 \mathrm{~kg}$ & $2 \mathrm{~g}$ \\
\hline \multirow[t]{3}{*}{ MF5 } & Dead Weight & Morehouse (modified) & 5 to $500 \mathrm{lbf}$ & $0.005 \%$ of reading \\
\hline & Calibrating Machine & & & \\
\hline & $\begin{array}{l}\text { Dead Weight } \\
\text { Calibrating Machine }\end{array}$ & FM\&T Metrology & 50 to $2400 \mathrm{lbf}$ & $0.005 \%$ of reading \\
\hline MF6 & Torque Standard & FM\&T Metrology & 0 to $700 \mathrm{lbf}-\mathrm{ft}$ & $0.17 \%$ of reading \\
\hline MF7 & $\begin{array}{l}\text { Transfer Torque } \\
\text { Standard }\end{array}$ & Norbar & 0 to $700 \mathrm{lbf}-\mathrm{ft}$ & $\begin{array}{l}0.2 \% \text { of range } \\
+0.5 \% \text { of reading }\end{array}$ \\
\hline
\end{tabular}




\section{Shock and Vibration}

\section{Vibration}

Standard accelerometers are calibrated at NIST and certified for the transfer of its sensitivity to the Vibration Systems transfer standard accelerometer. The vibration system transfers the sensitivity to other accelerometers. Sensitivity can be determined at ambient temperature or over the range of -70 to $+125^{\circ} \mathrm{C}$. A control standard is measured on the vibration system to verify that the system is functioning properly.

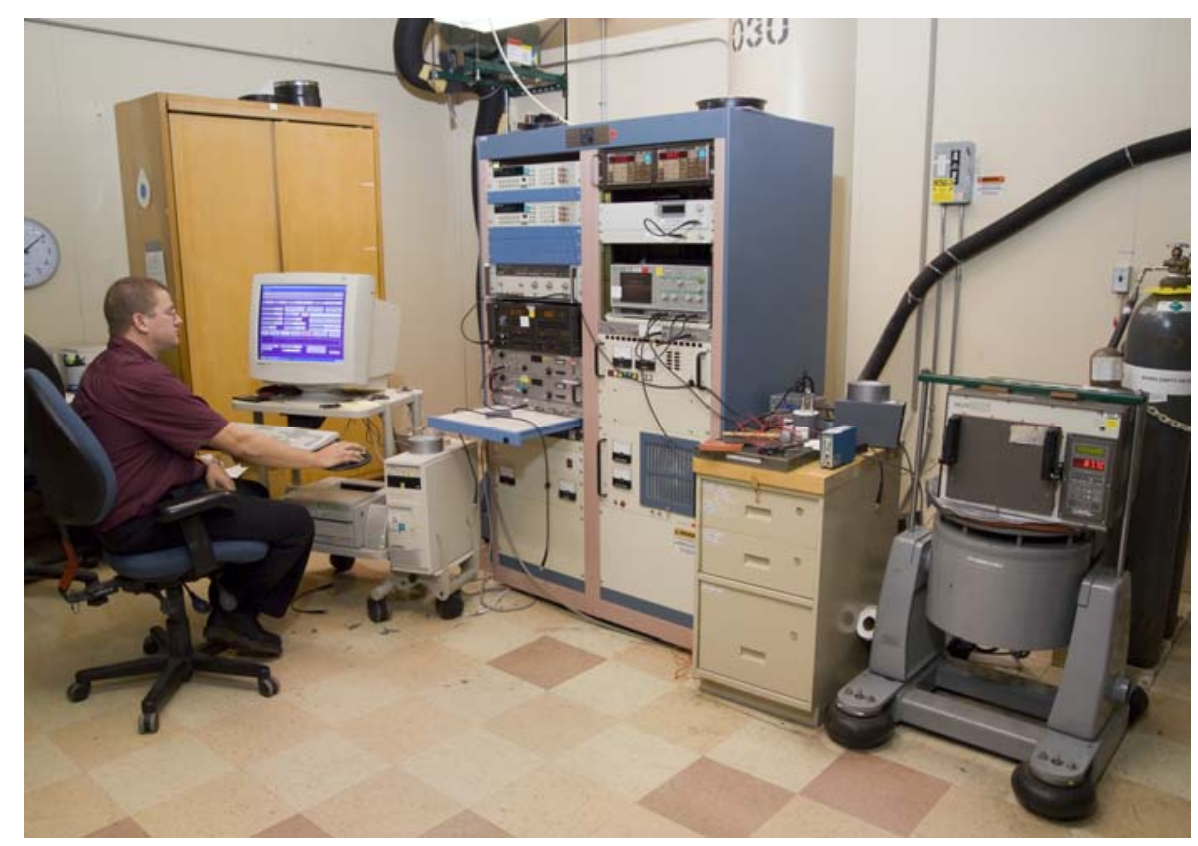

Vibration Calibration System with Environmental Capability

\section{Mechanical Shock}

The shock standard accelerometer and accelerometers calibrated for shock levels above 10,000 g's are calibrated using a velocity change shock pulse generator. The area of the shock pulse and the time of flight through a known distance are captured to calculate the sensitivity using the velocity change method. Accelerometers calibrated for shock less than 10,000 g's are calibrated in a back-to-back configuration on a hammer-activated shock pulse generator by comparison to the shock standard accelerometer. 


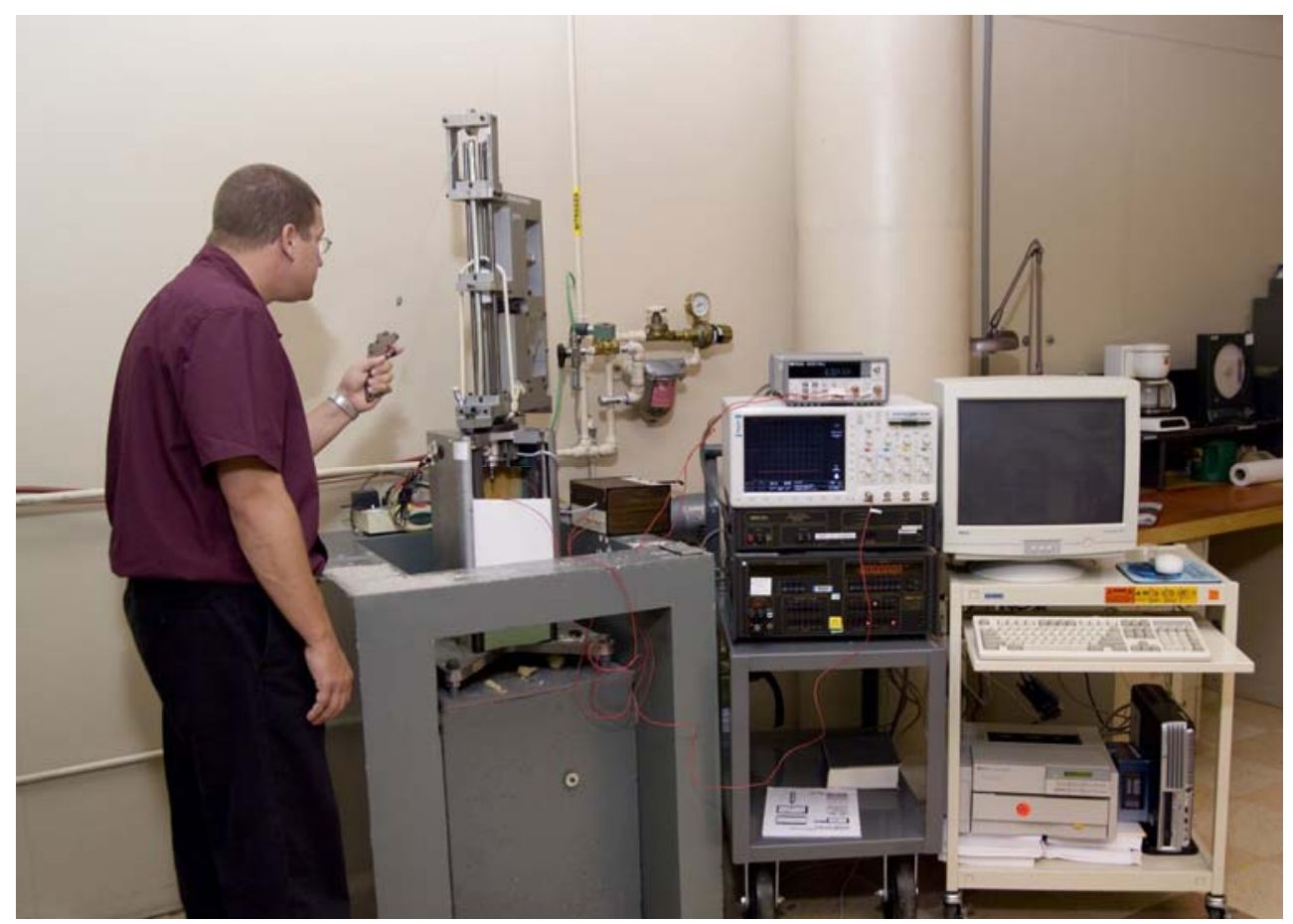

Velocity Change Shock Pulse Generator

\section{Sound Level}

Calibration of sound level is made by comparison of a sound level meter to a standard piston phone that is calibrated at NIST.

Vibration, Acceleration, Shock, Sound Level Measurement Capability

\begin{tabular}{|lll|}
\hline Type & Range & Measuring Uncertainty ( $\mathbf{\pm})(\boldsymbol{k}=\mathbf{2})$ \\
\hline Vibration & $\begin{array}{l}10 \mathrm{~g} \text { at } 100 \mathrm{~Hz} \text { to } 10 \mathrm{kHz} \\
\text { at }-65 \text { to }+125^{\circ} \mathrm{C}\end{array}$ & 1.8 to $4.0 \%$ \\
\hline Shock & $\begin{array}{l}2 \text { to } 15,000 \mathrm{~g} \\
\text { at } 0.05 \text { to } 10 \mathrm{~ms}\end{array}$ & 2.5 to $3.0 \%$ \\
\hline Sound Level & 94 to $124 \mathrm{~dB}$ at $250 \mathrm{~Hz}$ & $0.5 \mathrm{~dB}$ \\
\hline
\end{tabular}




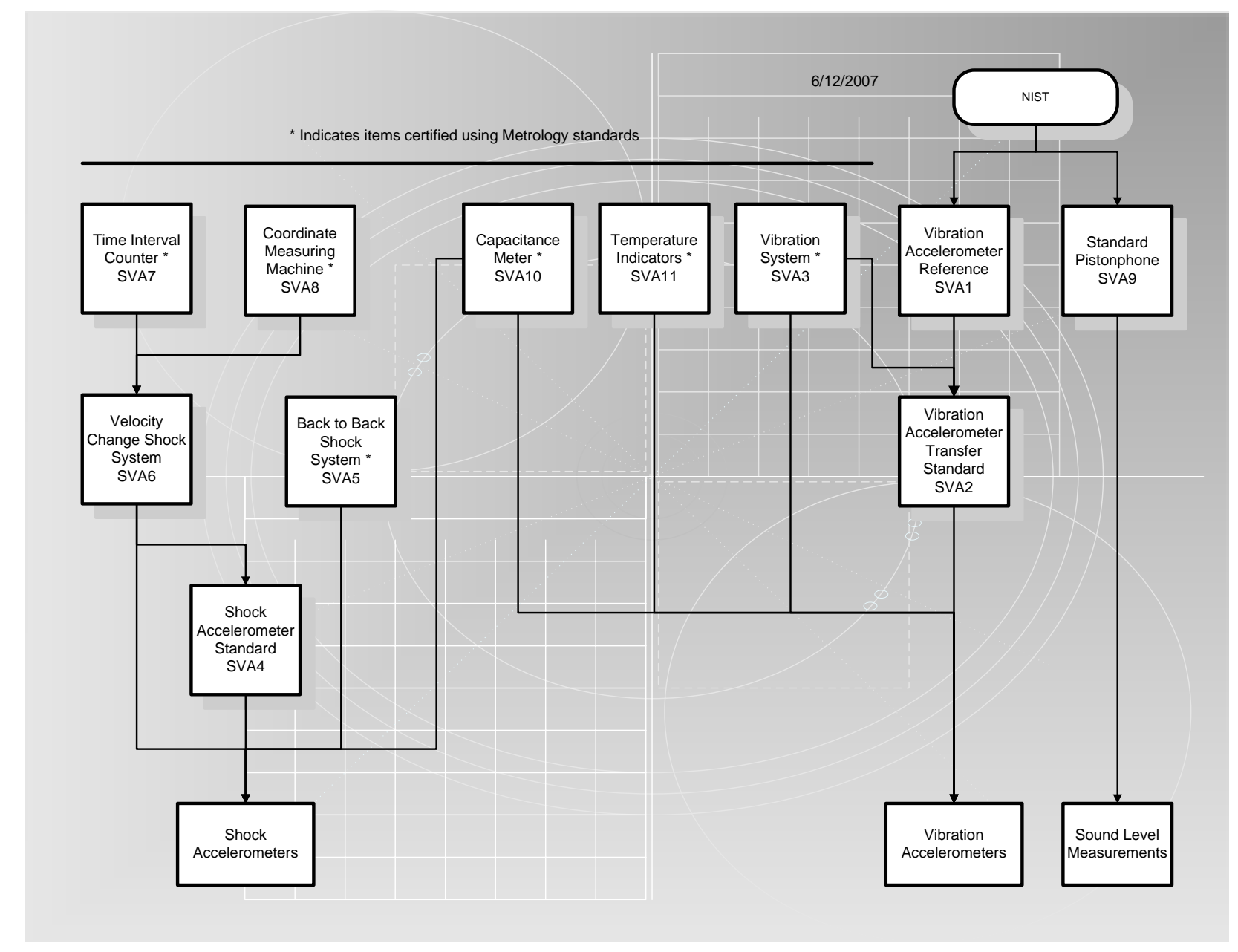

Vibration, Shock, Sound Level Traceability 
Vibration, Acceleration, and Shock Standards

\begin{tabular}{|c|c|c|c|c|}
\hline Code & Description & Manufacturer & Range & $\begin{array}{l}\text { Uncertainty }( \pm) \\
(k=2)\end{array}$ \\
\hline SVA1 & $\begin{array}{l}\text { Vibration } \\
\text { Accelerometer } \\
\text { Reference }\end{array}$ & Endevco & $\begin{array}{l}2 \text { to } 10 \mathrm{~g} \\
2 \mathrm{~Hz} \text { to } 10 \mathrm{kHz}\end{array}$ & 1 to $2 \%$ \\
\hline SVA2 & $\begin{array}{l}\text { Vibration } \\
\text { Accelerometer } \\
\text { Transfer Standard }\end{array}$ & $\begin{array}{l}\text { Unholtz } \\
\text { Dickie }\end{array}$ & $\begin{array}{l}2 \text { to } 10 \mathrm{~g} \\
2 \mathrm{~Hz} \text { to } 10 \mathrm{kHz}\end{array}$ & 1.8 to $2.5 \%$ \\
\hline SVA3 & Vibration System & FM\&T & $\begin{array}{l}2 \text { to } 20 \mathrm{~g} \\
2 \mathrm{~Hz} \text { to } 10 \mathrm{kHz}\end{array}$ & $\begin{array}{l}\text { Used only with other } \\
\text { calibrated measuring } \\
\text { standards }\end{array}$ \\
\hline SVA4 & $\begin{array}{l}\text { Shock } \\
\text { Accelerometer } \\
\text { Standard }\end{array}$ & Endevco & 10 to $10,000 \mathrm{~g}$ & $3 \%$ \\
\hline SVA5 & $\begin{array}{l}\text { Back to Back } \\
\text { Shock System }\end{array}$ & FM\&T Metrology & 100 to $10,000 \mathrm{~g}$ & $\begin{array}{l}\text { Used only with other } \\
\text { calibrated measuring } \\
\text { standards }\end{array}$ \\
\hline SVA6 & $\begin{array}{l}\text { Velocity Change } \\
\text { Shock System }\end{array}$ & FM\&T Metrology & 500 to $15,000 \mathrm{~g}$ & 2.5 to $3.0 \%$ \\
\hline SVA7 & $\begin{array}{l}\text { Time Interval } \\
\text { Counter }\end{array}$ & Hewlett Packard & $\begin{array}{l}10 \mu \mathrm{sec} \text { to } \\
1 \mathrm{~ms}\end{array}$ & $0.05 \%$ of reading \\
\hline SVA8 & $\begin{array}{l}\text { Coordinate } \\
\text { Measuring } \\
\text { Machine }\end{array}$ & Brown \& Sharp & 0 to $0.5 \mathrm{in}$. & $\begin{array}{l} \pm 0.0003 \text { in. from } \\
\text { nominal }\end{array}$ \\
\hline SVA9 & $\begin{array}{l}\text { Standard Piston } \\
\text { phone }\end{array}$ & $\mathrm{B}$ and $\mathrm{K}$ & $124 \mathrm{~dB}$ at $250 \mathrm{~Hz}$ & $0.25 \mathrm{~dB}$ \\
\hline SVA10 & Capacitance Meter & Data Precision & to $1 \mu \mathrm{F}$ & $\begin{array}{l}0.1 \% \text { of reading } \\
+1 \text { digit }\end{array}$ \\
\hline SVA11 & $\begin{array}{l}\text { Temperature } \\
\text { Indicators }\end{array}$ & Keithley & $-65^{\circ} \mathrm{C}$ to $+125^{\circ} \mathrm{C}$ & $1^{\circ} \mathrm{C}$ \\
\hline
\end{tabular}




\section{Environmental, Gas, Liquid}

\section{Temperature}

Temperature measurements in Metrology are based on the International Temperature Scale of 1990 (ITS-90). There are three primary standards at FM\&T for temperature calibration: fixed point cells, the standard platinum resistance thermometer (SPRT), and the platinum / 10\% rhodium versus platinum thermocouple (type S).

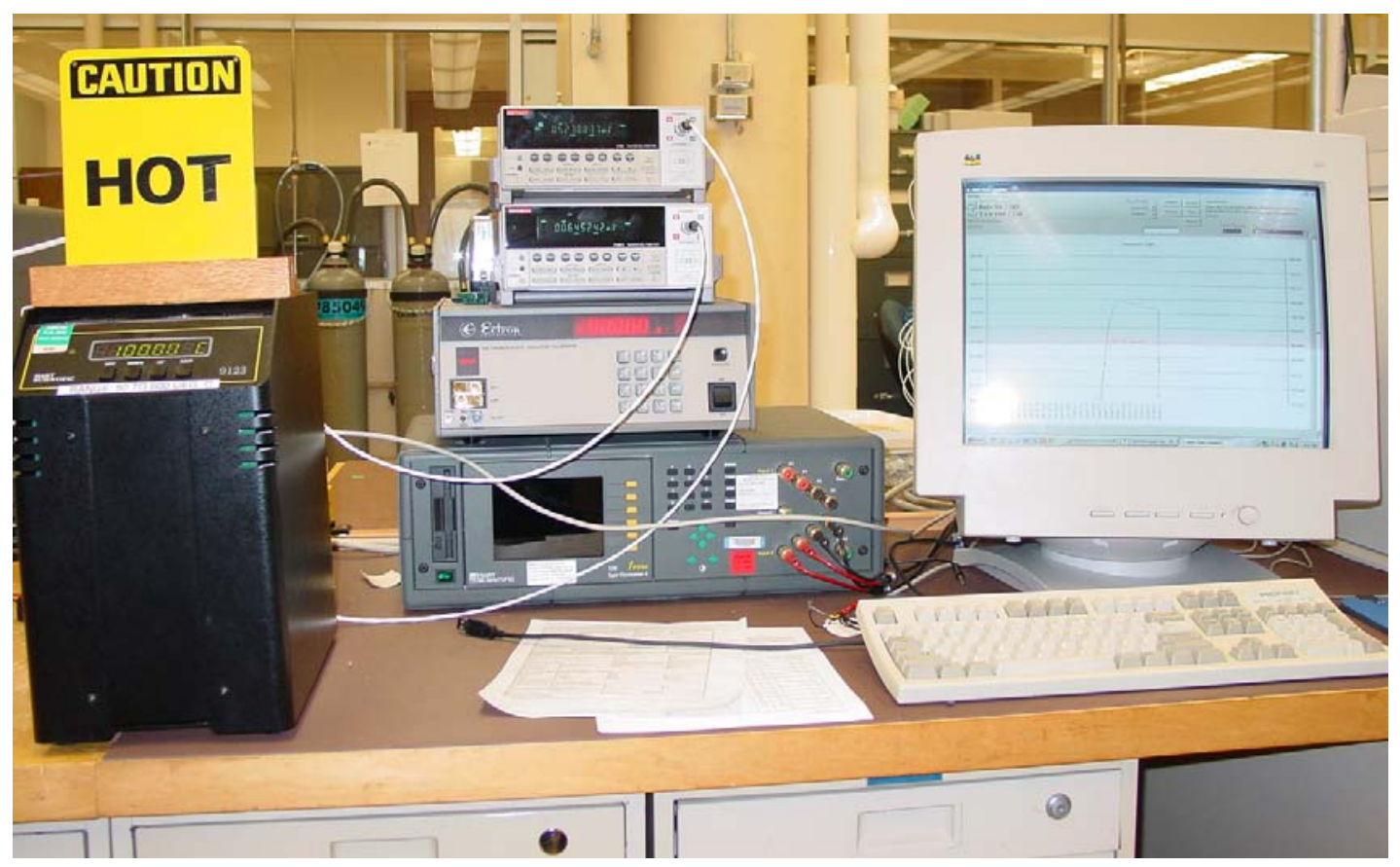

Automated Temperature Calibration

\section{$\underline{\text { SPRT Calibration Using a Fixed Point Temperature Cell }}$}

The SPRT covers the range from -180 to $660^{\circ} \mathrm{C}$ and is certified to an accuracy of $\pm(0.006$ to $0.05^{\circ} \mathrm{C}$ ). The type $\mathrm{S}$ thermocouple covers the range from 0 to $1450^{\circ} \mathrm{C}$ and is certified to an accuracy of $\pm 0.3^{\circ} \mathrm{C}$ from 0 to $1100^{\circ} \mathrm{C}$ increasing linearly to $1.6^{\circ} \mathrm{C}$ at $1450^{\circ} \mathrm{C}$.

Temperature environments for calibrations are created with two stirred baths, two drywell furnaces, a horizontal tube furnace, and fixed point temperature cells. The first stirred bath contains Fluorinert and covers the range from -80 to $+100^{\circ} \mathrm{C}$. The second bath contains silicon oil and covers the range from 50 to $260^{\circ} \mathrm{C}$. Both baths are used to calibrate thermocouples, SPRTs, thermistors, liquid-in-glass thermometers, and some solid state sensors. The drywells cover the range of -30 to $500^{\circ} \mathrm{C}$ and are used to calibrate thermocouples and industrial Platinum Resistance Thermometers. The horizontal tube furnace covers the range from 100 to $2700^{\circ} \mathrm{F}$ and is used to calibrate different types of thermocouples in air. Fixed-point temperature cells make possible very accurate single point temperature measurements for SPRTs and thermocouples. 
These cells are (temperatures in ITS-90 scale) Mercury $\left(-38.8344^{\circ} \mathrm{C}\right)$, Water $\left(0.01^{\circ} \mathrm{C}\right)$, Gallium $\left(29.7646^{\circ} \mathrm{C}\right)$, Indium $\left(156.5985^{\circ} \mathrm{C}\right)$, Tin $\left(231.928^{\circ} \mathrm{C}\right)$, Zinc $\left(419.527^{\circ} \mathrm{C}\right)$, and Aluminum $\left(660.323^{\circ} \mathrm{C}\right)$.

\section{Humidity}

Humidity calibrations are performed with two instruments. The first is a frost point generator capable of generating frost points from $-75^{\circ} \mathrm{C}$ to $10^{\circ} \mathrm{C} \pm 0.5^{\circ} \mathrm{C}$. The second is a two-pressure system that can generate humidity from $5 \%$ to $95 \% \mathrm{RH}$ to $\pm 0.5 \% \mathrm{RH}$.

The dew/frost point temperature and the ambient air temperature of the moist air are measured to determine absolute and relative humidity. Air flow through the test chamber can be varied from 0 to 140 SLPM.

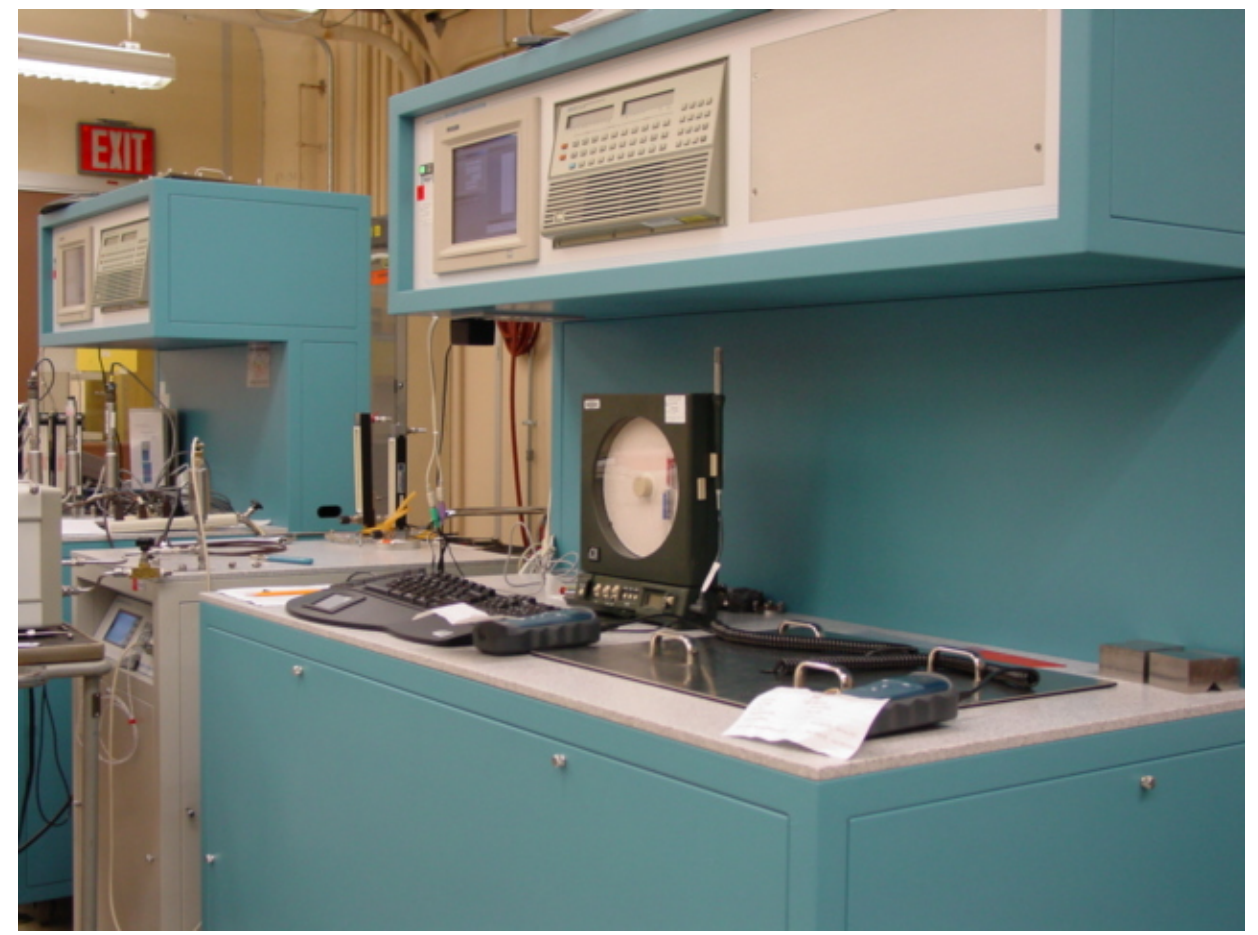

Humidity Calibration Using the Two-Pressure Method

Temperature, Humidity Measurement Capability

\begin{tabular}{|lll|}
\hline Type & Range & Measuring Uncertainty $( \pm)(\boldsymbol{k}=2)$ \\
\hline Temperature & $-183^{\circ} \mathrm{C}$ to $+660^{\circ} \mathrm{C}$ & $0.006^{\circ} \mathrm{C}$ to $0.02^{\circ} \mathrm{C}$ \\
& $420^{\circ} \mathrm{C}$ to $1100^{\circ} \mathrm{C}$ & $0.2 \%$ of reading \\
\hline Fixed Point & $-38.8344^{\circ} \mathrm{C}$ & $0.001^{\circ} \mathrm{C}$ \\
& $0.01^{\circ} \mathrm{C}$ & $0.0005^{\circ} \mathrm{C}$ \\
& $29.7646^{\circ} \mathrm{C}$ & $0.0005^{\circ} \mathrm{C}$ \\
\hline
\end{tabular}




\begin{tabular}{|c|c|c|}
\hline & $156.5985^{\circ} \mathrm{C}$ & $0.002^{\circ} \mathrm{C}$ \\
\hline & $231.928^{\circ} \mathrm{C}$ & $0.002^{\circ} \mathrm{C}$ \\
\hline & $419.527^{\circ} \mathrm{C}$ & $0.002^{\circ} \mathrm{C}$ \\
\hline & $660.3233^{\circ} \mathrm{C}$ & $0.005^{\circ} \mathrm{C}$ \\
\hline \multirow[t]{2}{*}{ Humidity } & $-75^{\circ} \mathrm{C}$ to $10.0^{\circ} \mathrm{C}$ & $0.5^{\circ} \mathrm{C}$ Frost/Dew Point \\
\hline & $5 \% \mathrm{RH}$ to $95 \% \mathrm{RH}$ & $0.5 \% \mathrm{RH}$ \\
\hline
\end{tabular}

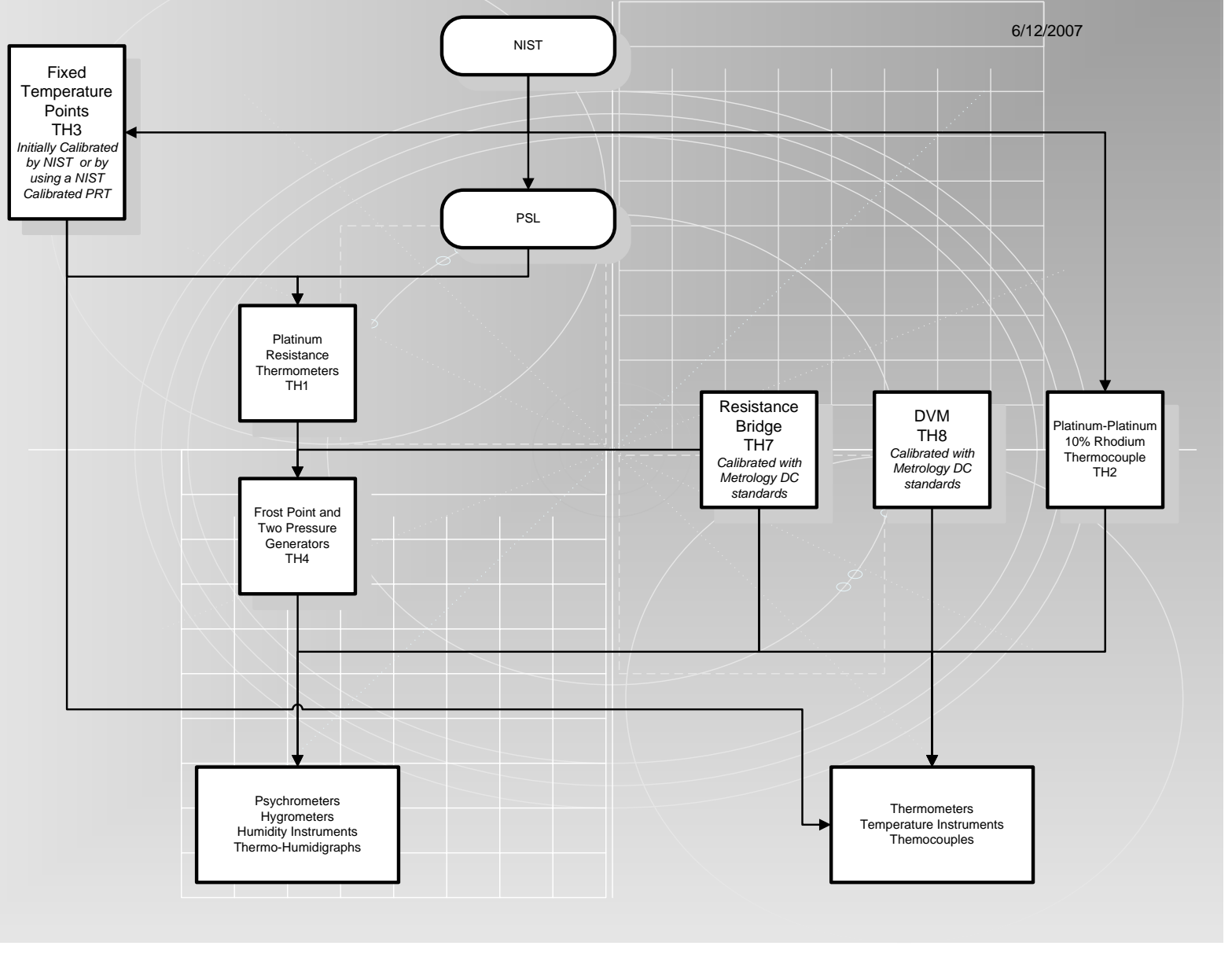

Temperature, Humidity Calibration Traceability 
Temperature, Humidity Standards

\begin{tabular}{|c|c|c|c|c|}
\hline Code & Description & Manufacturer & Range & Uncertainty $( \pm)(k=2)$ \\
\hline \multirow[t]{2}{*}{ TH1 } & Standard Platinum & Leeds \& Northrup & -186 to $0^{\circ} \mathrm{C}$ & $0.02^{\circ} \mathrm{C}$ \\
\hline & Resistance Thermometer & & -40 to $420^{\circ} \mathrm{C}$ & $0.006^{\circ} \mathrm{C}$ \\
\hline \multirow[t]{4}{*}{ TH2 } & Platinum - & Leeds \& Northrup & 0 to $1100^{\circ} \mathrm{C}$ & $0.3^{\circ} \mathrm{C}$ increasing \\
\hline & Platinum $10 \%$ & & & linearly to $1.6^{\circ} \mathrm{C}$ at \\
\hline & Rhodium & & & $1450^{\circ} \mathrm{C}$ \\
\hline & Thermocouple & & & \\
\hline \multirow[t]{7}{*}{ TH3 } & Fixed Temperature Points & & & \\
\hline & Mercury & Isotech & $-38.8344^{\circ} \mathrm{C}$ & $0.001^{\circ} \mathrm{C}$ \\
\hline & TP Water & Jarrett & $0.01^{\circ} \mathrm{C}$ & $0.0005^{\circ} \mathrm{C}$ \\
\hline & Gallium & Isotech & $29.7646^{\circ} \mathrm{C}$ & $0.0005^{\circ} \mathrm{C}$ \\
\hline & Indium & Hart Scientific & $156.5985^{\circ} \mathrm{C}$ & $0.002^{\circ} \mathrm{C}$ \\
\hline & Tin & Isotech & $231.928^{\circ} \mathrm{C}$ & $0.002^{\circ} \mathrm{C}$ \\
\hline & Zinc & Hart Scientific & $419.527^{\circ} \mathrm{C}$ & $0.002^{\circ}$ \\
\hline \multirow[t]{2}{*}{ TH4 } & Frost Point Generator & Thunder Scientific & -70 to $10^{\circ} \mathrm{C}$ & $0.5^{\circ} \mathrm{C}$ Frost/Dew Point \\
\hline & Two-Pressure Generator & Thunder Scientific & 5 to $95 \% \mathrm{RH}$ & $0.5 \% \mathrm{RH}$ \\
\hline TH7 & Resistance Ratio Bridge & ASL & 0 to 1.2 & $1 \mathrm{ppm}$ \\
\hline TH8 & DVM & Keithley & 0 to $1000 \mathrm{Vdc}$ & $\begin{array}{l}0.015 \% \text { of reading } \\
+4 \text { digits }\end{array}$ \\
\hline
\end{tabular}




\section{GAS}

\section{Pressure}

Pressure gages are calibrated using dead-weight piston gages. The effective area of the 0 to 500 psi reference is determined by NIST. The effective area of the 0 to 15,000 psi reference is determined by PSL. The effective area of the 0 to 100,000 psi reference is determined at FM\&T with NIST traceable standards. True mass for each reference is determined using the NIST Mass MAP program.

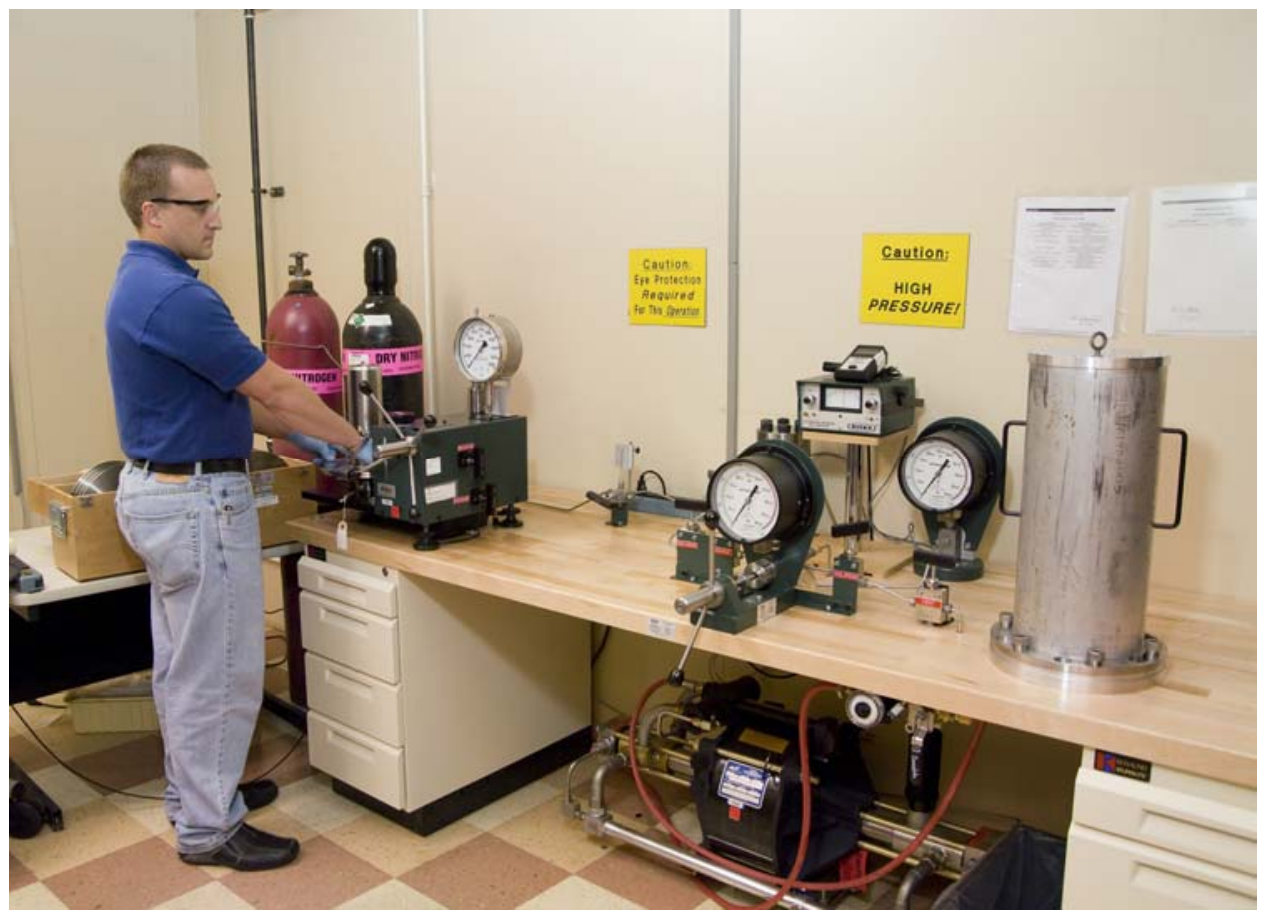

30,000 psig Gas Pressure Calibration 


\section{Gas Flow}

Gas flow meters are calibrated by direct comparisons to PSL-certified flow meters or volumetric displacement devices. Volume, time, pressure, and temperature measurements are combined to obtain a value of flow. All measurement parameters are certified and NIST traceable.

\section{$\underline{\text { Air Velocity }}$}

Air velocity meters are calibrated using a certified wind tunnel. The wind tunnel is calibrated using NIST-certified hot wire anemometer and pilot tube.

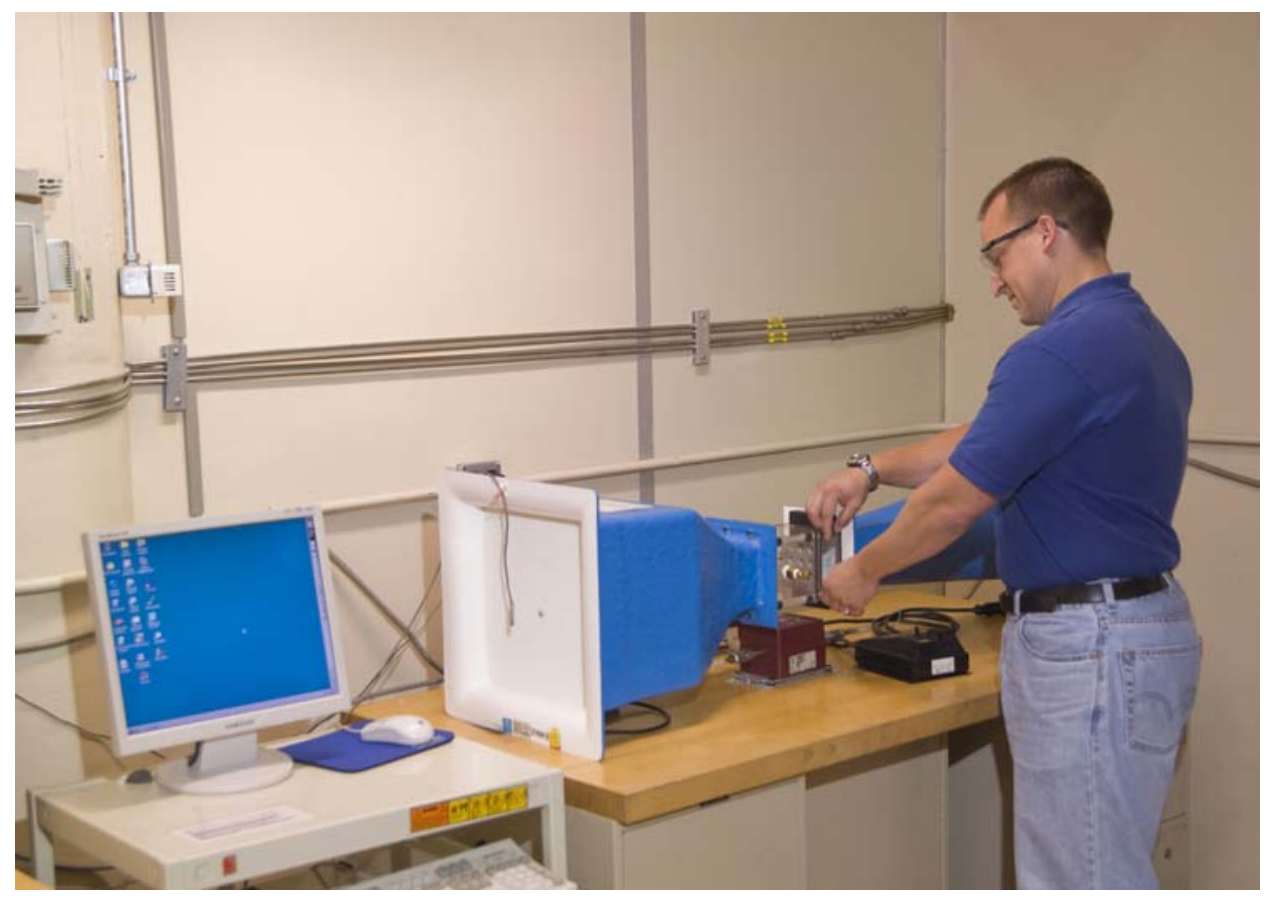

Air Velocity Calibration 


\section{Vacuum}

Vacuum calibrations at or below $10^{-3} \mathrm{mmHg}$ are performed using a molecular drag gage, sometimes called a spinning rotor gage (SRG). The SRG is calibrated by NIST.

Vacuum calibrations above $10^{-3} \mathrm{mmHg}$ are performed using either a capacitance manometer or digital Quartz manometer, depending upon the range of the gage. The manometers are calibrated using a PSL-certified dead weight piston gage.

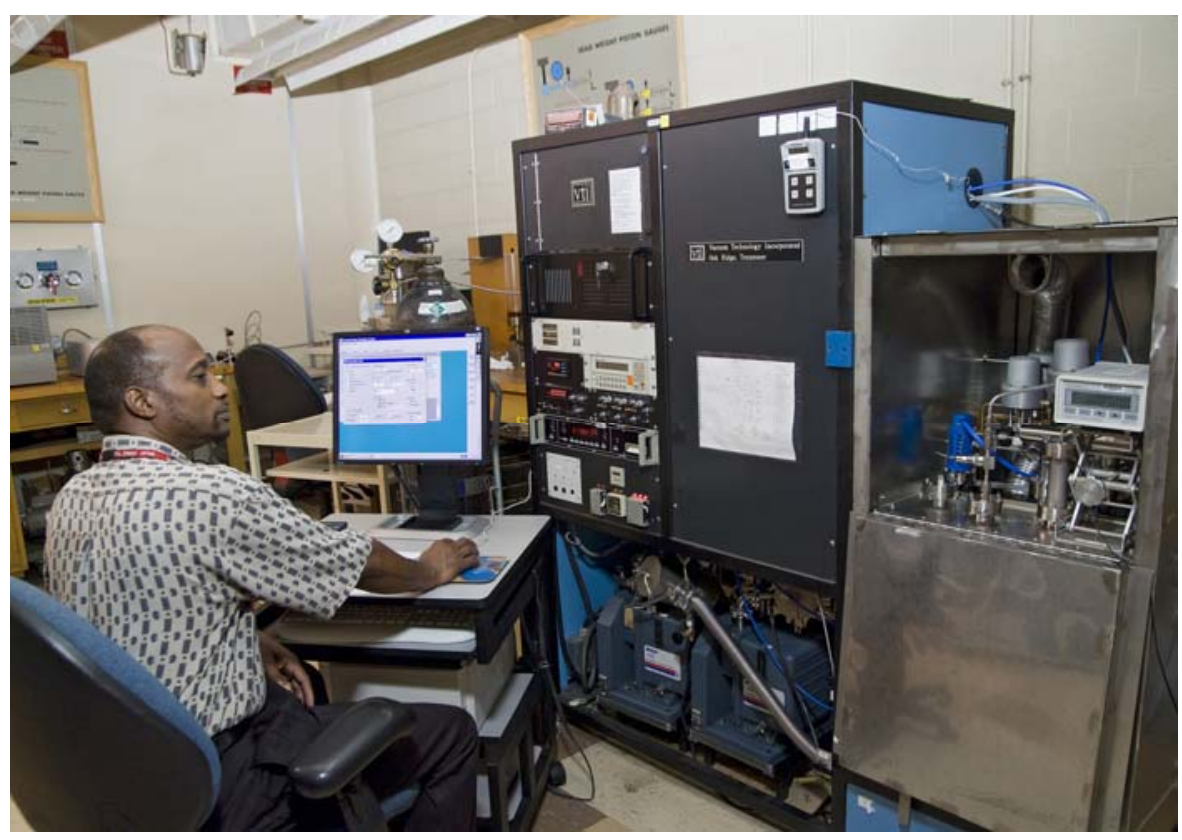

Vacuum Gage Calibration 


\section{Gas Leaks}

Gas leak devices are calibrated by making direct comparisons to PSL-certified leaks on a mass spectrometer or using the pressure, volume, temperature (PVT) technique. All measurement parameters of the PVT technique are certified and NIST traceable. A precision gas analyzer is used to evaluate the composition of the leak gas.

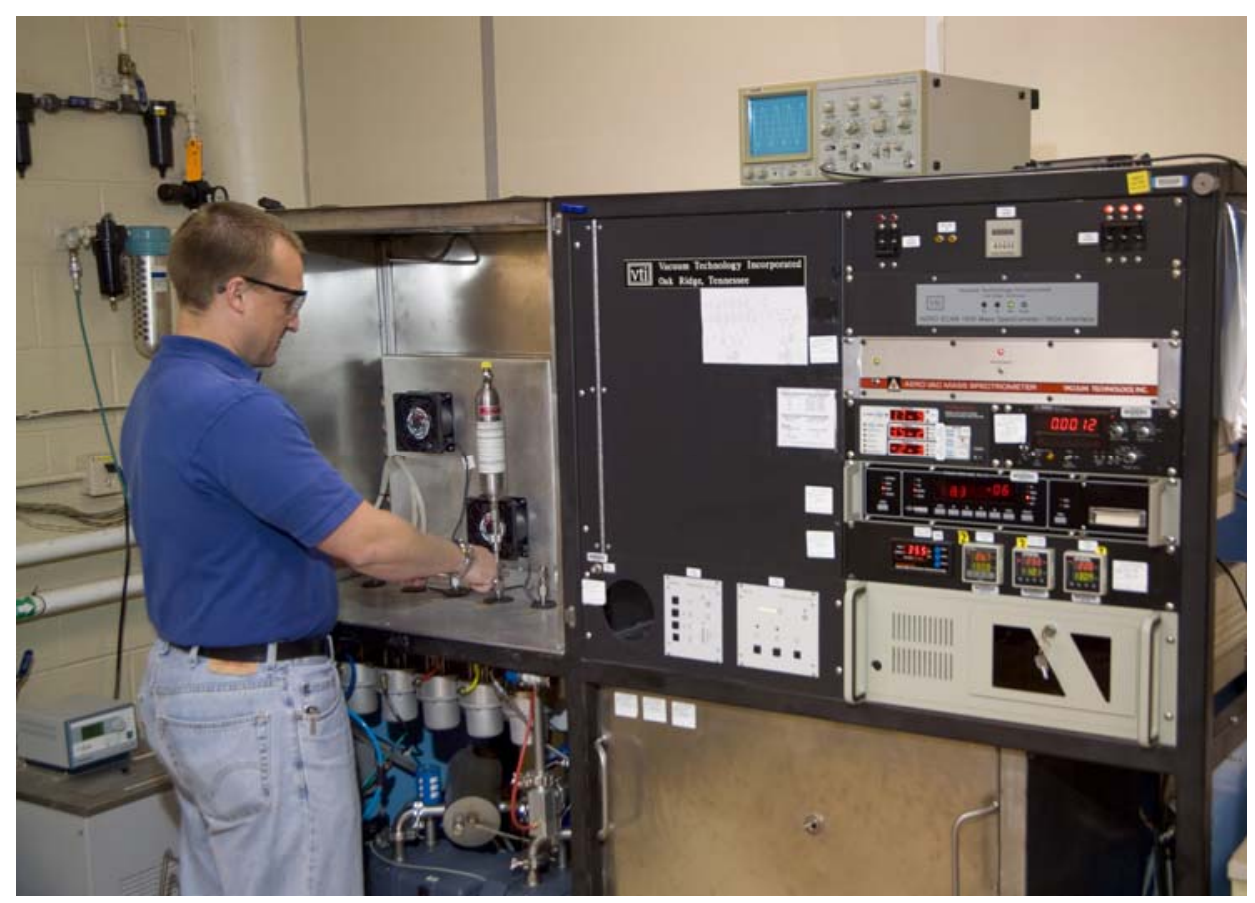

Standard Leak Calibration 


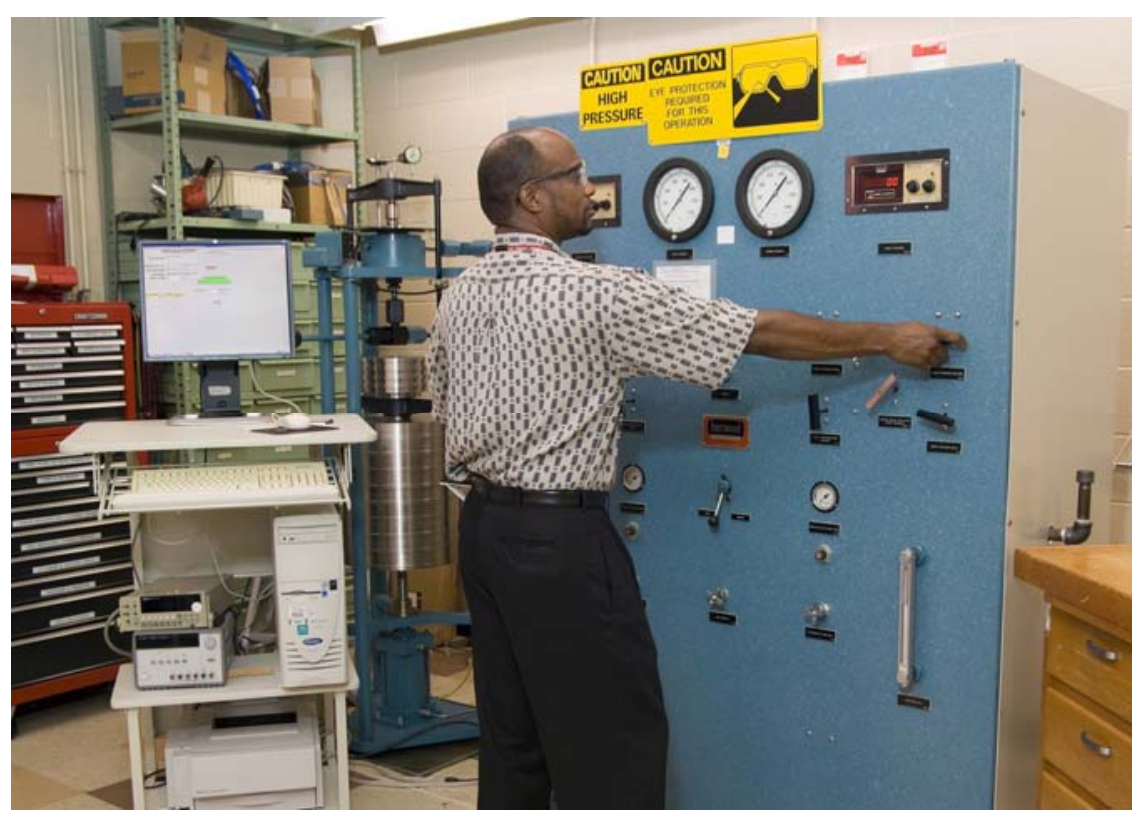

Pressure Calibration Using Controlled Clearance Dead-Weight Piston Gage

Gas, Liquid Measurement Capability

\begin{tabular}{|c|c|c|}
\hline Type & Range & Measuring Uncertainty $( \pm)(k=2)$ \\
\hline \multirow[t]{3}{*}{ Pressure } & $\begin{array}{l}\text { Absolute } \\
10^{-8} \text { to } 10^{-4} \text { torr } \\
10^{-3} \text { to } 0.05 \text { torr }\end{array}$ & $\begin{array}{l}10 \% \\
(0.0003+0.005 \times \text { reading }) \text { torr }\end{array}$ \\
\hline & $\begin{array}{l}1 \text { to } 10 \text { torr } \\
10 \text { to } 1100 \text { torr } \\
0.1 \text { to } 500 \text { psia }\end{array}$ & $\begin{array}{l}(0.0005+0.003 \times \text { reading }) \text { torr } \\
(0.03+0.0002 \times \text { reading }) \text { torr } \\
(0.01+0.0002 \times \text { reading }) \mathrm{psi}\end{array}$ \\
\hline & $\begin{array}{l}\text { Gage } \\
500 \text { to } 1800 \text { psig } \\
600 \text { to } 15,000 \text { psig } \\
15,000 \text { to } 100,000 \text { psig }\end{array}$ & $\begin{array}{l}0.07 \% \\
0.06 \% \\
0.065 \%\end{array}$ \\
\hline \multirow[t]{3}{*}{ Air Velocity } & 30 to $250 \mathrm{sfpm}$ & $4.5 \mathrm{sfpm}+1 \%$ of Reading \\
\hline & 251 to $1500 \mathrm{sfpm}$ & $6.0+1 \%$ of Reading \\
\hline & 1501 to 9500 sfpm & $30 \mathrm{sfpm}+2 \%$ of Reading \\
\hline Gas Flow & $\begin{array}{l}1 \text { to } 50,000 \text { sccm } \\
50 \text { to } 1800 \text { slpm }\end{array}$ & $\begin{array}{l}1 \% \\
2 \%\end{array}$ \\
\hline Leak Rate & $\begin{array}{l}1 \times 10^{-1} \text { to } 5 \times 10^{-9} \\
\text { standard } \mathrm{cm}^{3} / \mathrm{s} \text { STP } \\
10^{-10} \text { standard } \mathrm{cm}^{3} / \mathrm{s} \text { STP }\end{array}$ & $\begin{array}{l}5 \text { to } 15 \% \\
25 \%\end{array}$ \\
\hline
\end{tabular}




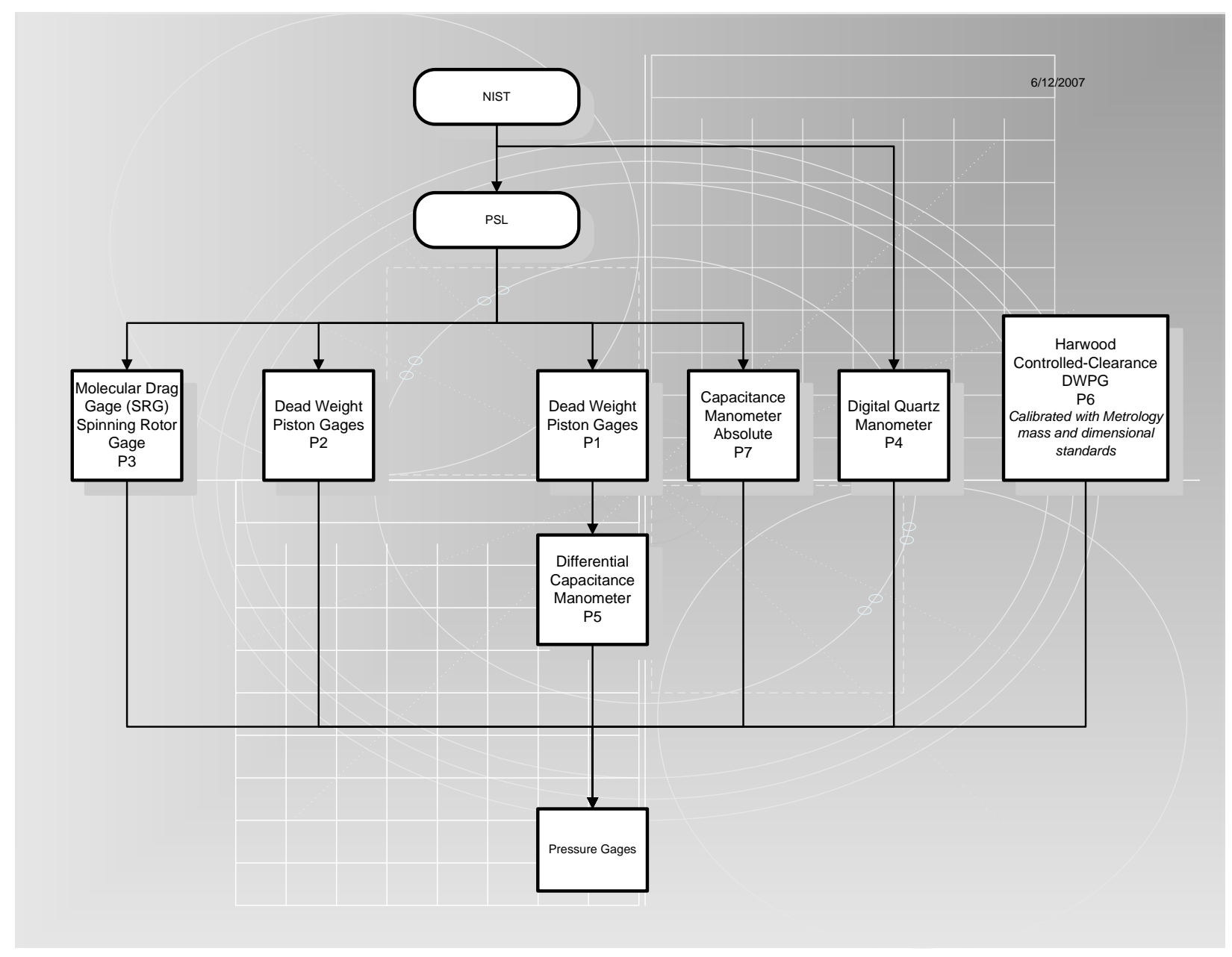

\section{Pressure Calibration Traceability}

Pressure Standards

\begin{tabular}{lllll}
\hline Code & Description & Manufacturer & Range & Uncertainty $( \pm)(\boldsymbol{k}=\mathbf{2})$ \\
\hline P1 & Piston Gage & CEC & 0.2 to $600 \mathrm{psi}$ & $0.015 \%$ \\
& & DH Instruments & 20 to $1800 \mathrm{psi}$ & $0.015 \%$ \\
P2 & Piston Gages & Ruska & 0.1 to $40,000 \mathrm{psig}$ & $0.02 \%$ \\
P3 & Molecular Drag & MKS & $10^{-6}$ torr & $8 \%$ \\
& Gage & & $10^{-5}$ torr & $4 \%$ \\
& & $10^{-4}$ torr & $3 \%$ \\
& & $10^{-3}$ torr & $3 \%$ \\
& & $10^{-2}$ torr & $3 \%$
\end{tabular}




\section{Pressure Standards}

\begin{tabular}{lllll}
\hline Code & Description & Manufacturer & Range & Uncertainty $( \pm)(\mathbf{k}=2)$ \\
\hline P4 & $\begin{array}{l}\text { Digital Quartz } \\
\text { Manometer } \\
\text { (Differential) } \\
\text { (remove) }\end{array}$ & Paroscientific & 0.1 to 1100 torr & $\begin{array}{l}(0.015+0.00005 \text { x reading) torr } \\
(0.004+0.0001 \text { x reading) } \\
\text { psi(remove) }\end{array}$ \\
P5 & $\begin{array}{l}\text { Capacitance } \\
\text { Manometer } \\
\text { (Differential) }\end{array}$ & MKS & -0 to 30 psia(remove) & $0.0005+0.00344^{*}$ reading \\
P6 & $\begin{array}{l}\text { Controlled- } \\
\text { Clearance DWPG }\end{array}$ & Harwood & $100^{-3}$ to 10 torr & $0.0033+0.0026^{*}$ reading \\
P7 & $\begin{array}{l}\text { Capacitance } \\
\text { Manometer } \\
\text { (Absolute) }\end{array}$ & MKS & 1000 to 100,000 psi & $0.03 \%$ of reading \\
& & $10^{-3}$ to 0.1 torr & $0.00025+0.008 *$ reading \\
\hline
\end{tabular}

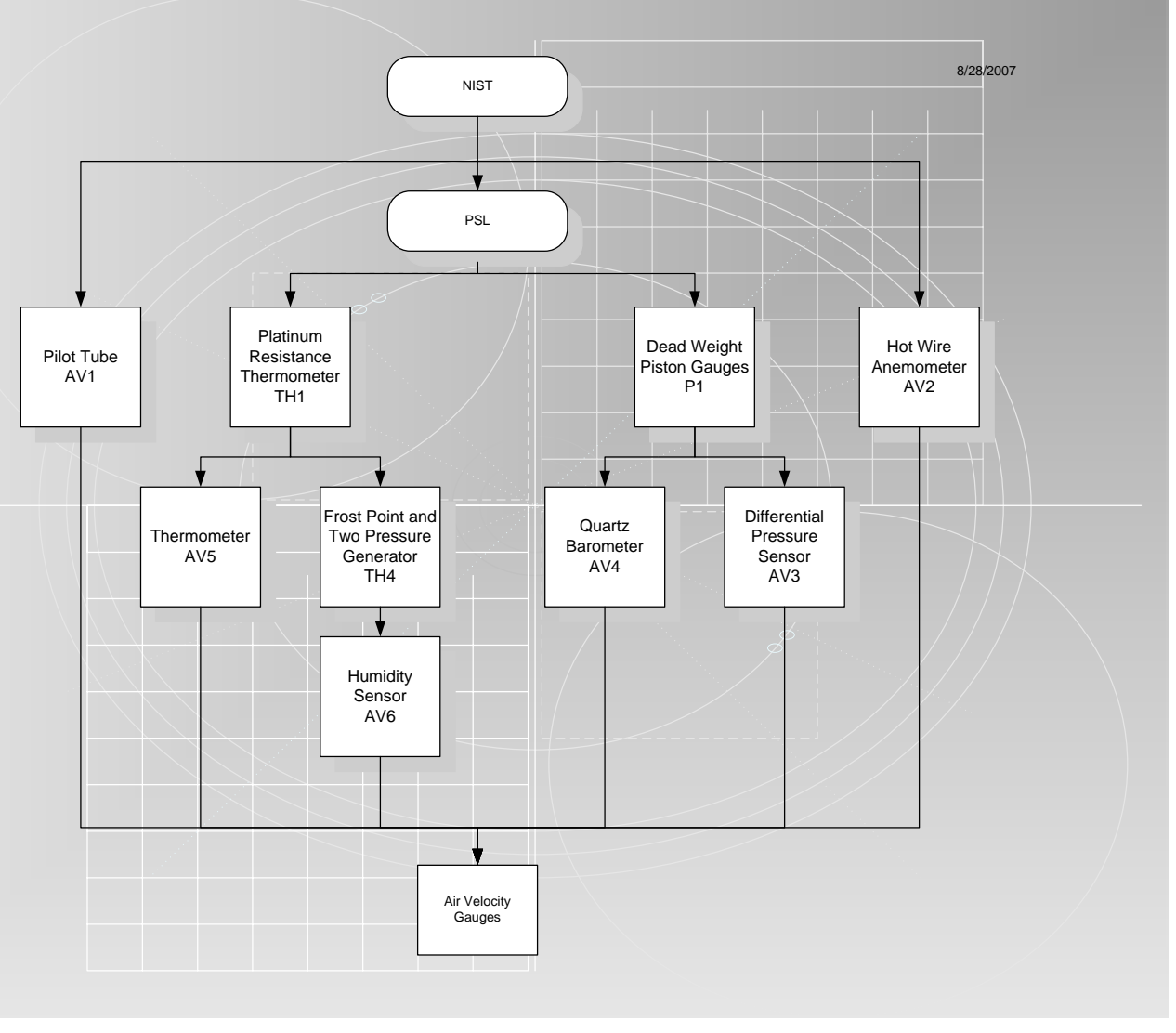

Air Velocity Calibration Traceability 


\section{Air Velocity Standards}

\begin{tabular}{|c|c|c|c|c|}
\hline Code & Description & Manufacturer & Range & Uncertainty $( \pm)(k=2)$ \\
\hline AV1 & Pilot tube & & 1000 to $9500 \mathrm{sfpm}$ & $\begin{array}{l}1.2+0.0007 \text { Reading } \wedge 0.5+ \\
647281 / \text { Reading } \wedge \%\end{array}$ \\
\hline \multirow[t]{2}{*}{ AV2 } & $\begin{array}{l}\text { Hot Wire } \\
\text { Anemometer }\end{array}$ & TSI & 50 to $250 \mathrm{sfpm}$ & $\begin{array}{l}2.05+1.35 E-08 * \text { Reading^3 }+ \\
1164.43 \text { / Reading^} 2 \text { sfpm }\end{array}$ \\
\hline & & & 25 to $1000 \mathrm{sfpm}$ & $\begin{array}{l}5.44+0.00283 * \text { Reading }+396.54 \\
\text { / Reading sfpm }\end{array}$ \\
\hline \multirow[t]{2}{*}{ AV3 } & Differential & MKS & 0 to 10 Torr & $0.004 *$ Reading \\
\hline & & & 10 to 100 Torr & $0.32 \%$ \\
\hline AV4 & Barometer & Paroscientific & & $0.3 \mathrm{mmHg}$ \\
\hline AV5 & Thermometer & $\begin{array}{l}\text { Yellow } \\
\text { Springs }\end{array}$ & & $0.1^{\circ} \mathrm{C}$ \\
\hline AV6 & Humidity Sensor & FM\&T & & $5 \%$ \\
\hline
\end{tabular}




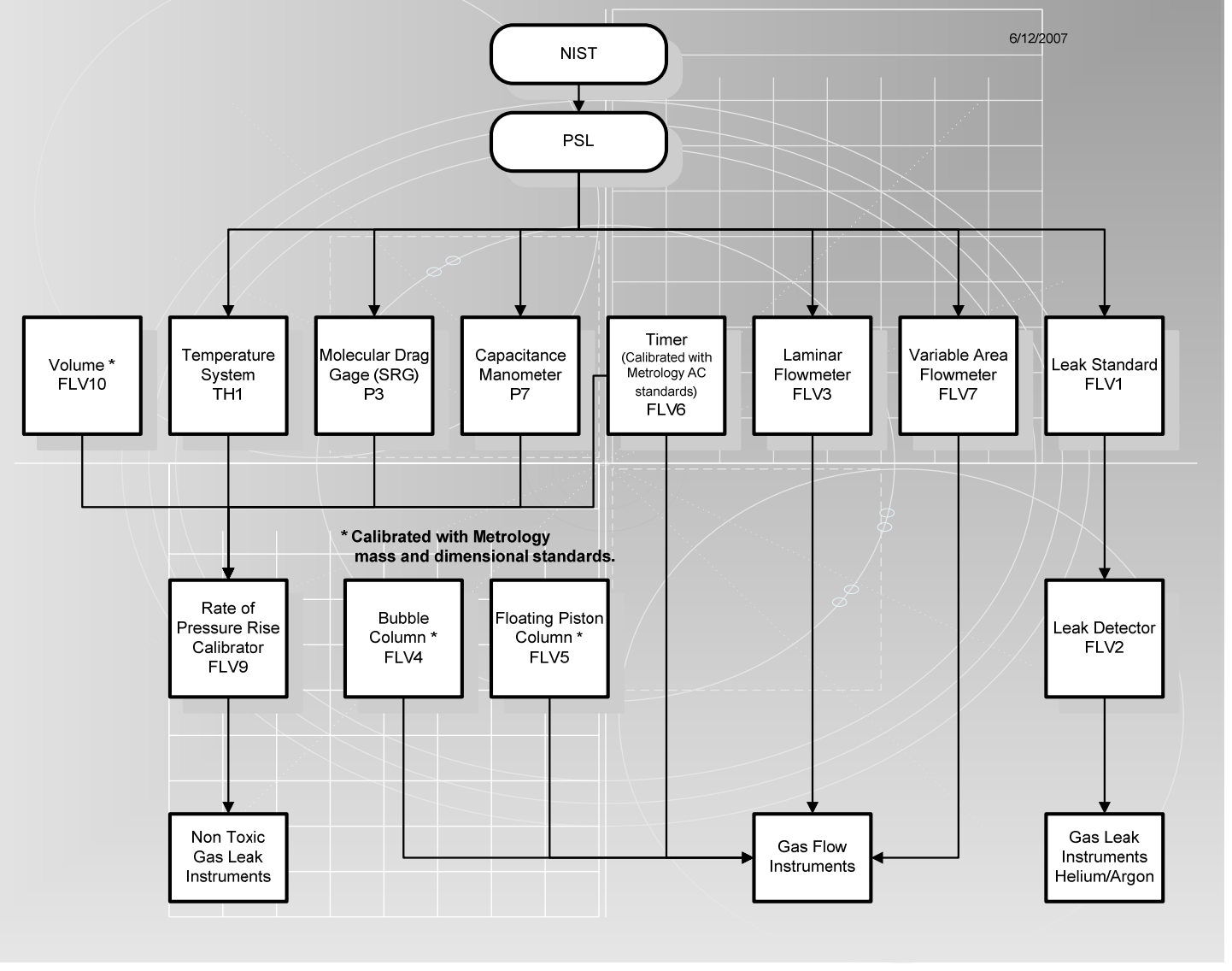

Gas Leak, Flow Rate Calibration Traceability 


\section{Gas Leak, Flow Rate Standards}

\begin{tabular}{|c|c|c|c|c|}
\hline Code & Description & Manufacturer & Range & Uncertainty $( \pm)(k=2)$ \\
\hline FLV1 & Leak Standard & $\begin{array}{l}\text { Veeco/VIC/VT } \\
\text { I }\end{array}$ & $\begin{array}{l}1 \times 10^{-7} \text { to } 1 \times 10^{-6} \mathrm{~cm}^{3} / \mathrm{s} \mathrm{STP} \\
1 \times 10^{-9} \text { to } 9.9 \times 10^{-8} \mathrm{~cm}^{3} / \mathrm{s} \text { STP } \\
2 \times 10^{-10} \text { to } 9.9 \times 10^{-10} \mathrm{~cm}^{3} / \mathrm{s} \mathrm{STP}\end{array}$ & $\begin{array}{l}4 \text { to } 8 \% \\
5 \text { to } 10 \% \\
9 \text { to } 15 \%\end{array}$ \\
\hline FLV2 & Leak Detector & $\begin{array}{l}\text { Vacuum } \\
\text { Technology, } \\
\text { Inc. }\end{array}$ & $\begin{array}{l}1 \times 10^{-6} \text { to } 1 \times 10^{-9} \mathrm{~cm}^{3} / \mathrm{s} \text { STP } \\
1 \times 10^{-9} \text { to } 2 \times 10^{-10} \mathrm{~cm}^{3} / \mathrm{s} \mathrm{STP}\end{array}$ & $\begin{array}{l}3 \% \\
3.5 \%\end{array}$ \\
\hline \multirow[t]{2}{*}{ FLV3 } & $\begin{array}{l}\text { Laminar Flow } \\
\text { meter }\end{array}$ & $\begin{array}{l}\text { National } \\
\text { Instrument } \\
\text { Laboratories }\end{array}$ & 1 to 500 SLPM & 1 to $2 \%$ \\
\hline & & CME & 180 to 1800 SLPM & 18 SCFM \\
\hline FLV4 & $\begin{array}{l}\text { Bubble } \\
\text { Column }\end{array}$ & $\begin{array}{l}\text { Matheson } \\
\text { Scientific }\end{array}$ & Volume $50 \mathrm{~cm}^{3}$ & $0.05 \mathrm{~cm}^{3}$ \\
\hline FLV5 & $\begin{array}{l}\text { Floating Piston } \\
\text { Column }\end{array}$ & MKS & 1 to 50,000 SCCM & $0.25 \%$ \\
\hline FLV6 & Timer & $\begin{array}{l}\text { Standard } \\
\text { Electric }\end{array}$ & 0 to 999 seconds & $(0.1 \%+1$ count $)$ \\
\hline FLV7 & $\begin{array}{l}\text { Variable Area } \\
\text { Flow meter }\end{array}$ & Fisher \& Porter & 8 to 23 SCFM & 0.3 SCFM \\
\hline FLV8 & $\begin{array}{l}\text { Standard } \\
\text { Viscosity Oils }\end{array}$ & $\begin{array}{l}\text { Cannon } \\
\text { Instrument }\end{array}$ & 0.3 to $5,300,000 \mathrm{mPa} \bullet \mathrm{s}$ & 0.58 to $0.83 \%$ \\
\hline FLV9 & $\begin{array}{l}\text { Leak } \\
\text { Calibrator } \\
\text { (Rate of } \\
\text { pressure rise) }\end{array}$ & VTI & $1 \times 10^{-3}$ to $1 \times 10^{-7} \mathrm{~cm}^{3} / \mathrm{s} \mathrm{STP}$ & 3 to $5 \%$ \\
\hline FLV10 & Volume & Whitey & 25 to $1100 \mathrm{~cm}^{3}$ & $0.1 \%$ \\
\hline
\end{tabular}




\section{Electrical}

\section{Electrical Measurement}

\section{Voltage}

The basic reference for DC voltage measurements consists of two groups of zener voltage references. Both groups are re-certified by intercomparison tests with a Josephson array voltage standard from the PSL. A precision potentiometer is used for voltage measurements to 10 volts. The potentiometer and a precision divider are used for measurements up to 1500 volts. High voltage dividers calibrated by the PSL or by NIST are used for measurements up to 150 kilovolts.

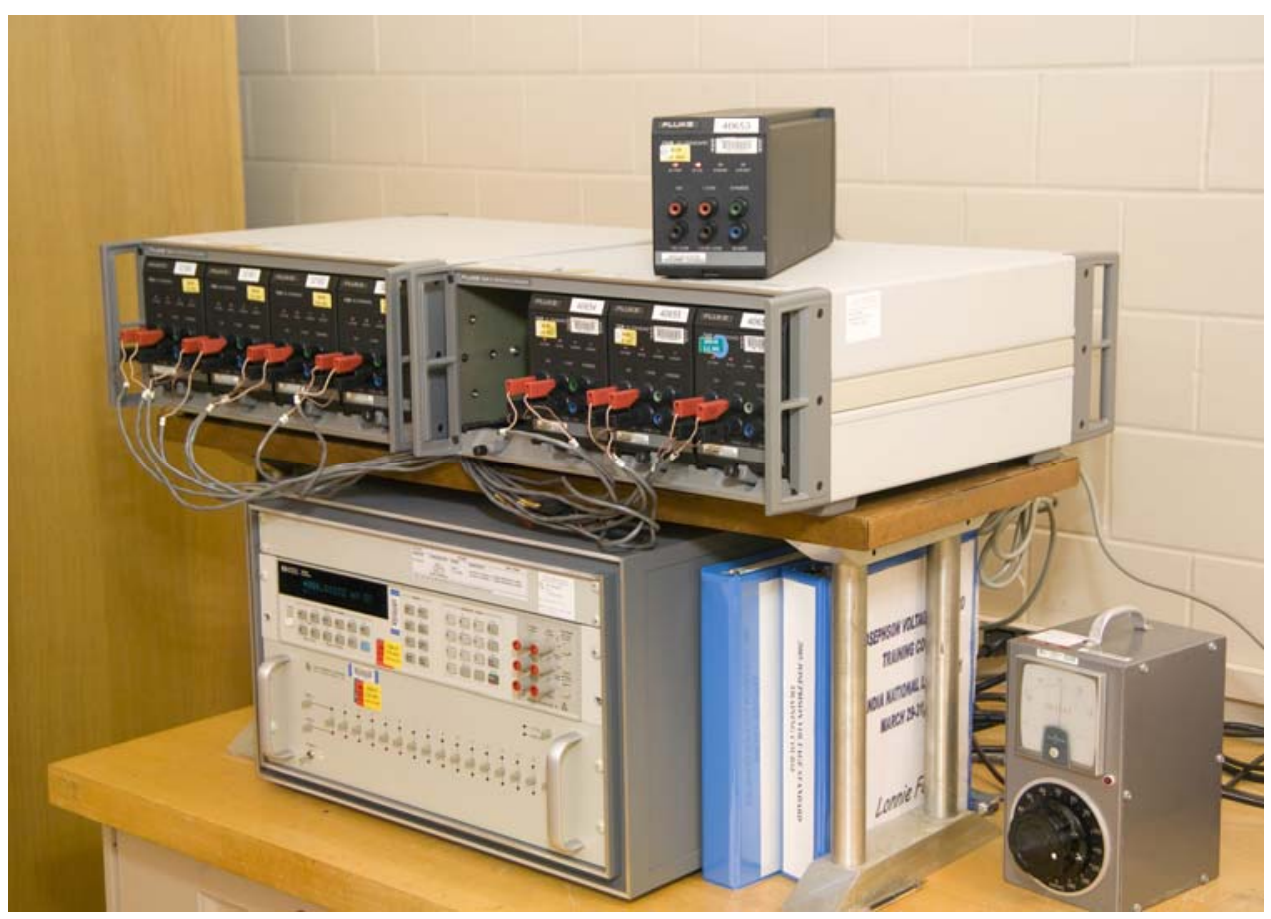

DC Voltage Inter-comparison

\section{$\underline{\text { DC Current }}$}

Measurements of current up to 2 amperes are made using resistance and voltage standards. Shunts calibrated by the PSL are used for current measurements from 2 amperes to 300 amperes. 


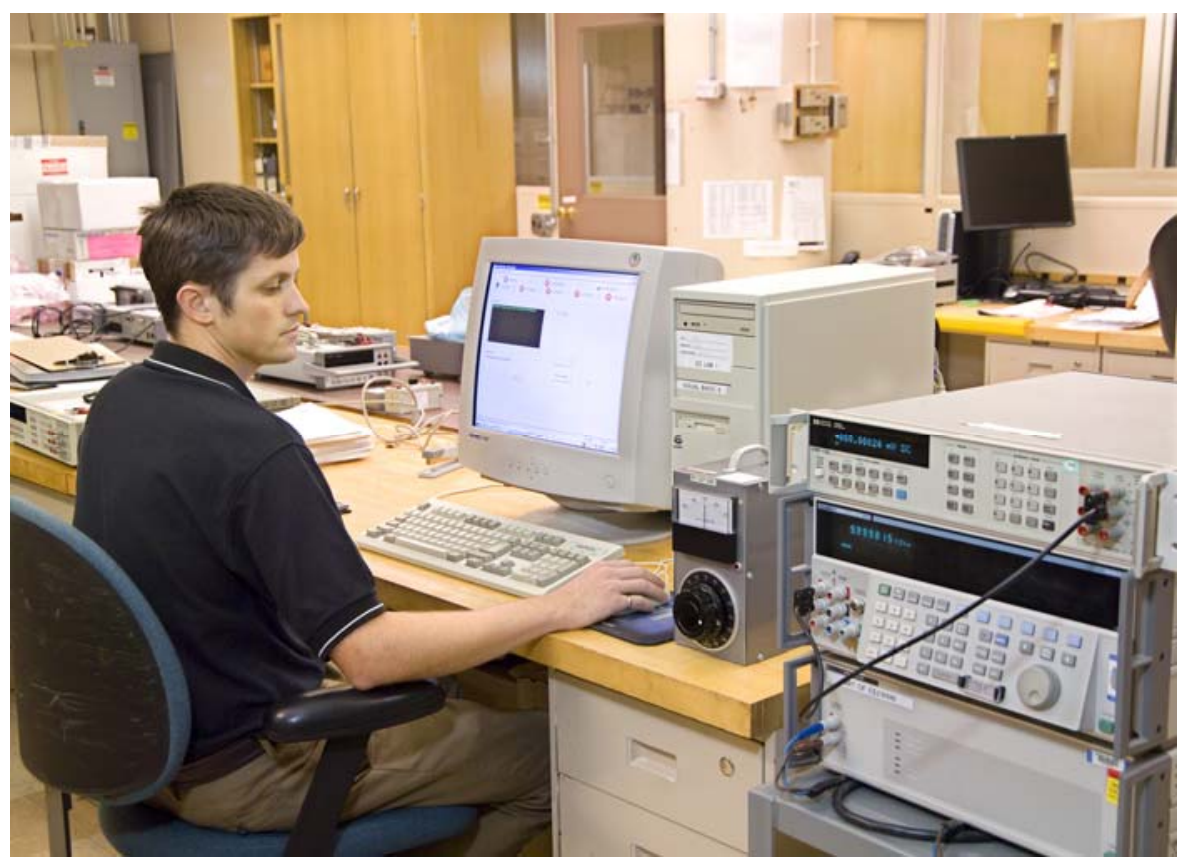

Automated Digital Multimeter Calibration 


\section{Electrical DC Measurement Capability}

\begin{tabular}{|c|c|c|}
\hline Type & Range & $\begin{array}{l}\text { Measuring Uncertainty }( \pm) \\
(k=2)\end{array}$ \\
\hline DC Voltage & $\begin{array}{l}1.018 \mathrm{~V} \\
1 \mathrm{~V} \\
1 \mathrm{~V} \text { to } 1000 \mathrm{~V} \\
10 \mathrm{kV} \\
100 \mathrm{kV} \\
1.50 \mathrm{kV}\end{array}$ & $\begin{array}{l}0.41 \mathrm{ppm} \\
0.45 \mathrm{ppm} \\
3.1 \mathrm{ppm} \\
137 \mathrm{ppm} \\
150 \mathrm{ppm} \\
260 \mathrm{ppm}\end{array}$ \\
\hline DC Current & $\begin{array}{l}10^{-10} \mathrm{~A} \\
10^{-9} \mathrm{~A} \\
10^{-8} \mathrm{~A} \\
10^{-7} \text { to } 10^{-6} \mathrm{~A} \\
10^{-5} \text { to } 0.3 \mathrm{~A} \\
>0.3 \text { to } 15 \mathrm{~A} \\
>15 \text { to } 100 \mathrm{~A} \\
>100 \text { to } 500 \mathrm{~A}\end{array}$ & $\begin{array}{l}0.1 \% \\
0.1 \% \\
0.04 \% \\
0.04 \% \\
0.004 \% \\
0.005 \% \\
0.007 \% \\
0.008 \%\end{array}$ \\
\hline DC Resistance & $\begin{array}{l}10^{-4} \text { to } 10^{-1} \Omega \\
10^{0} \Omega \\
1 \mathrm{k} \Omega \\
1 \text { to } 100 \Omega \\
100 \text { to } 1 \mathrm{M} \Omega \\
10^{7} \Omega \\
10^{8} \Omega\end{array}$ & $\begin{array}{l}3.6 \mathrm{ppm} \\
0.5 \mathrm{ppm} \\
1.9 \mathrm{ppm} \\
3.6 \mathrm{ppm} \\
3.6 \mathrm{ppm} \\
13.4 \mathrm{ppm} \\
16.7 \mathrm{ppm}\end{array}$ \\
\hline DC Magnetic Flux Density & $\begin{array}{l}\text { Transverse Probe: } \\
20 \text { to } 10,000 \text { Gauss } \\
\text { Axial Probe: } \\
50 \text { to } 2000 \text { Gauss }\end{array}$ & $\begin{array}{l}2 \% \text { to } 4 \% \\
2 \% \text { to } 4 \%\end{array}$ \\
\hline
\end{tabular}




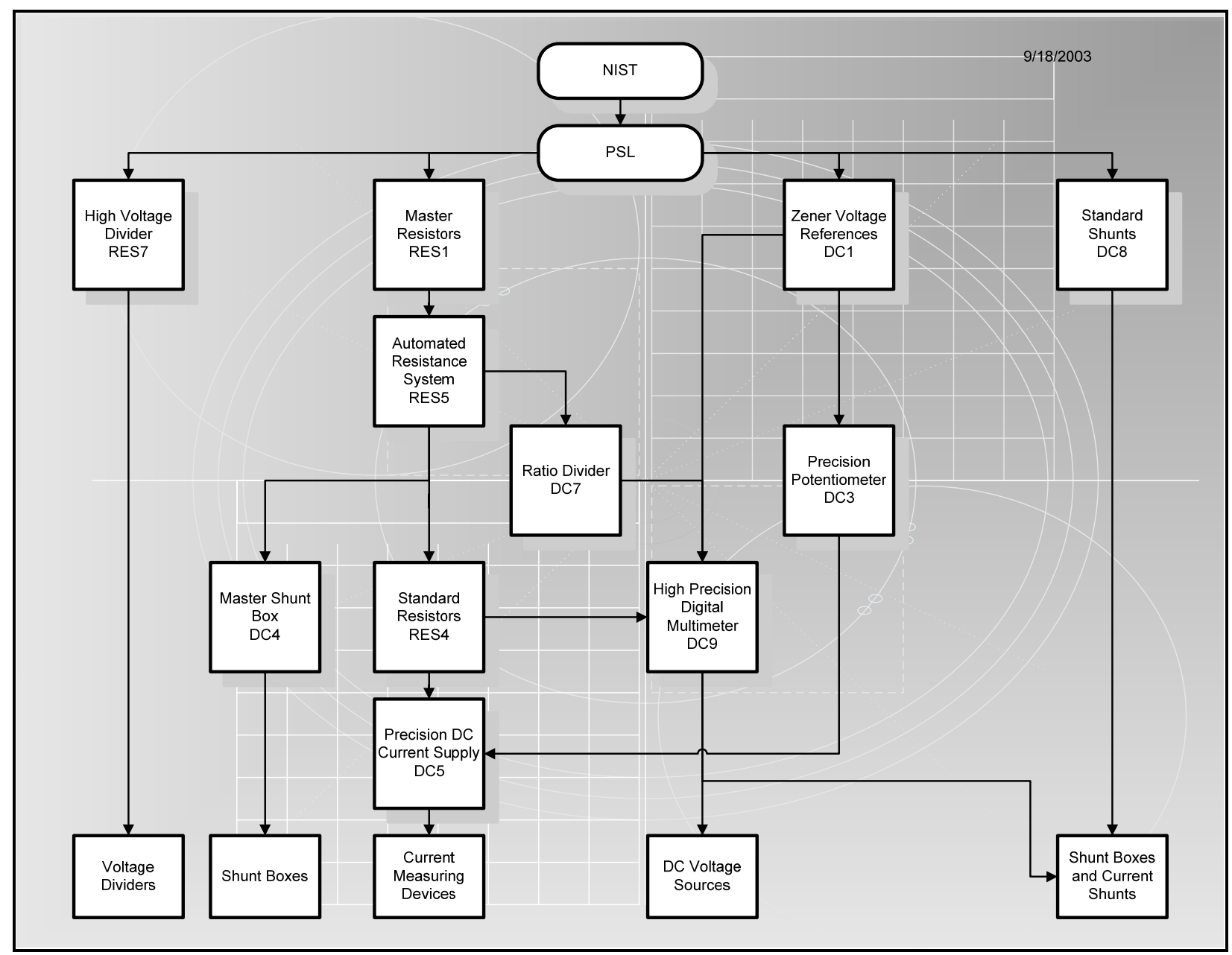

DC Current, Voltage, and Ratio Traceability 


\section{Current and Voltage Standards}

\begin{tabular}{|c|c|c|c|c|}
\hline Code & Description & Manufacturer & Range & Uncertainty $( \pm)(k=2)$ \\
\hline DC1 & $\begin{array}{l}\text { Zener Voltage } \\
\text { References }\end{array}$ & Fluke & $\begin{array}{l}1.018 \mathrm{~V} \text { and } \\
10 \mathrm{~V} \text { nominal }\end{array}$ & 0.33 ppm \\
\hline \multirow[t]{3}{*}{ DC2 } & Voltage Dividers & Sensitive Research & 10 to $100 \mathrm{kV}$ & 0.008\% $\quad$ (Calibrated by NIST) \\
\hline & & Spellman & 60 to $150 \mathrm{kV}$ & 0.02\% (Calibrated by PSL) \\
\hline & & Fluke & 1 to $10 \mathrm{kV}$ & 0.033\% (Calibrated by Metrology) \\
\hline DC3 & $\begin{array}{l}\text { Precision } \\
\text { Potentiometer }\end{array}$ & $\begin{array}{l}\text { Measurements } \\
\text { International }\end{array}$ & 0 to $10 \mathrm{~V}$ & $(0.25 \mathrm{ppm}+0.0375 \mu \mathrm{V})$ \\
\hline DC4 & $\begin{array}{l}\text { Master Shunt } \\
\text { Boxes }\end{array}$ & Leeds \& Northrup & 0.015 to $15 \mathrm{~A}$ & 33 ppm \\
\hline DC5 & $\begin{array}{l}\text { Precision DC } \\
\text { Current Supply }\end{array}$ & FM\&T Metrology & $\begin{array}{l}1.5 \mu \mathrm{A} \text { to } 15 \mathrm{~A} \\
\text { (7 ranges) }\end{array}$ & ( $0.02 \%$ or $1 \mathrm{nA})$, whichever is greater \\
\hline DC6 & $\begin{array}{l}\text { Calibrated DC } \\
\text { Voltage Source }\end{array}$ & Fluke & $\begin{array}{l}0 \text { to } 220 \mathrm{mV} \\
>0.22 \text { to } 220 \mathrm{~V} \\
>220 \text { to } 1100 \mathrm{~V}\end{array}$ & $\begin{array}{l}8 \mathrm{ppm}+3 \mathrm{ppm} \text { of range } \\
8 \mathrm{ppm}+0.5 \mathrm{ppm} \text { of range } \\
9 \mathrm{ppm}+0.5 \mathrm{ppm} \text { of range }\end{array}$ \\
\hline DC7 & Ratio Divider & Guildline & $1: 1$ to $10,000: 1$ & $2 \mathrm{ppm}$ \\
\hline DC8 & Shunt Standards & $\begin{array}{l}\text { Leeds \& Northrup } \\
\text { Guildline }\end{array}$ & $\begin{array}{l}0 \text { to } 15 \mathrm{~A} \\
0 \text { to } 100 \mathrm{~A} \\
0 \text { to } 300 \mathrm{~A} \\
0 \text { to } 500 \mathrm{~A}\end{array}$ & $\begin{array}{l}0.0033 \% \\
0.0066 \% \\
0.0066 \% \\
0.0066 \%\end{array}$ \\
\hline DC9 & $\begin{array}{l}\text { High Precision } \\
\text { DMM }\end{array}$ & Hewlett-Packard & $\begin{array}{l}0.1 \text { to } 100 \mathrm{~V} \\
0.1 \text { to } 1000 \mathrm{~V}\end{array}$ & $\begin{array}{l}25 \text { ppm (Ratio) } \\
11 \text { ppm to } 25 \text { ppm (DC Voltage) }\end{array}$ \\
\hline
\end{tabular}




\section{Resistance}

The reference for resistance measurements is a Thomas $1 \mathrm{ohm}$ and a $10 \mathrm{kohm}$ standard resistor that are certified by the Sandia PSL. These resistors in conjunction with an automated resistance system are used to measure resistance from $0.001 \mathrm{ohm}$ to 100 megaohm. From 100 megaohm to 10 teraohm, resistance measurements are accomplished using a high resistance meter.

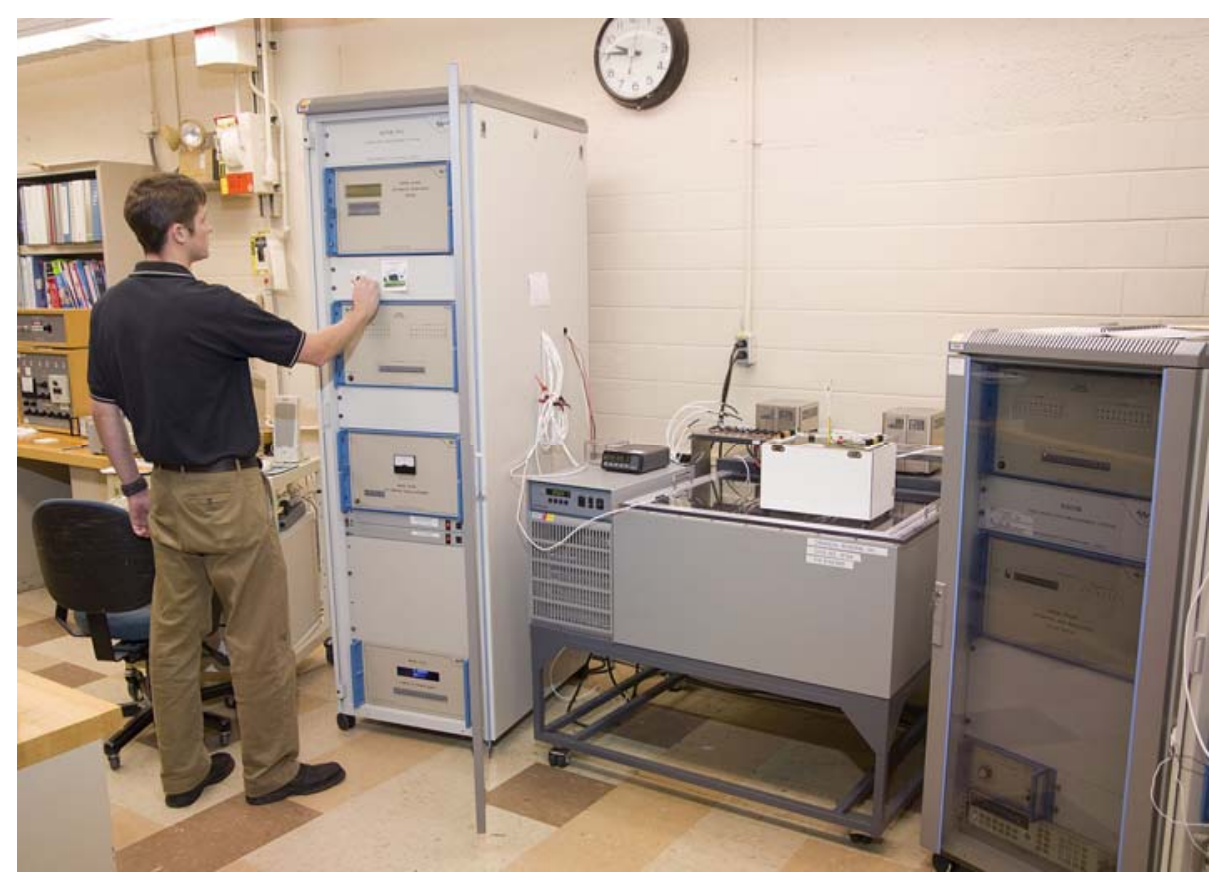

Automated Resistance Measuring System 


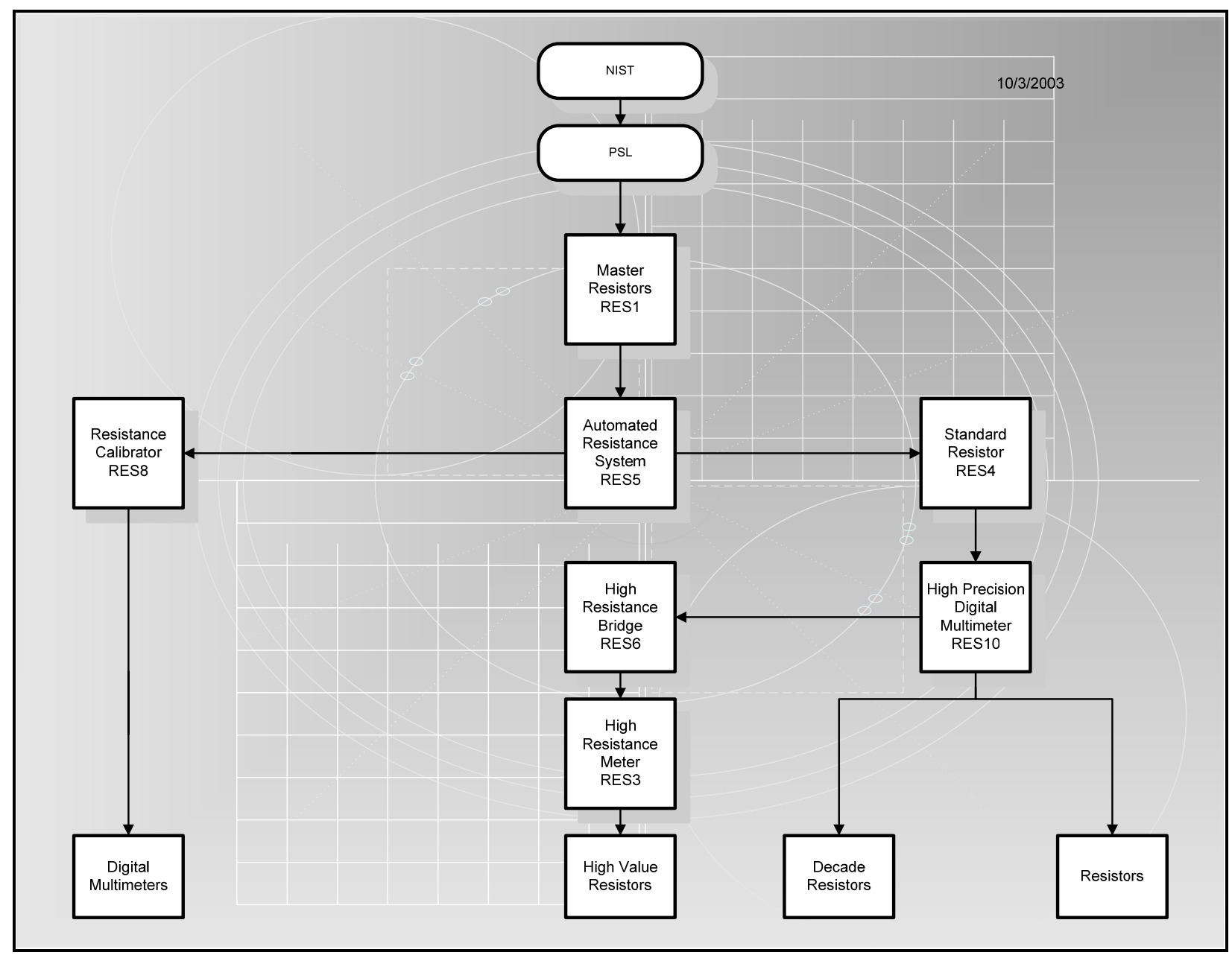

DC Resistance Traceability 


\section{Resistance and Ratio Standards}

\begin{tabular}{|c|c|c|c|c|}
\hline Code & Description & Manufacturer & Range & Uncertainty $( \pm)(k=2)$ \\
\hline RES1 & Master Resistors & $\begin{array}{l}\text { Leeds \& Northrup } \\
\text { ESI }\end{array}$ & $\begin{array}{l}1 \Omega \\
10 \mathrm{k} \Omega\end{array}$ & $\begin{array}{l}0.333 \mathrm{ppm} \\
0.6 \mathrm{ppm}\end{array}$ \\
\hline RES3 & $\begin{array}{l}\text { High Resistance } \\
\text { Meter }\end{array}$ & Guildline & $10^{5}$ to $10^{12} \Omega$ & $150 \mathrm{ppm}$ to $5000 \mathrm{ppm}$ \\
\hline RES4 & Standard Resistors & $\begin{array}{l}\text { Leeds \& Northrup, } \\
\text { Julie, Guildline }\end{array}$ & $0.001 \Omega$ to $100 \mathrm{M} \Omega$ & $5 \mathrm{ppm}$ to $25 \mathrm{ppm}$ \\
\hline RES5 & $\begin{array}{l}\text { Automated } \\
\text { Resistance System }\end{array}$ & $\begin{array}{l}\text { Measurements } \\
\text { International }\end{array}$ & $0.0001 \Omega$ to $100 \mathrm{M} \Omega$ & $0.1 \mathrm{ppm}$ to $60 \mathrm{ppm}$ (Ratio) \\
\hline RES6 & $\begin{array}{l}\text { High Resistance } \\
\text { Measuring System }\end{array}$ & Mid-Eastern & $10^{3}$ to $10^{13} \Omega$ & $0.2 \%$ \\
\hline RES7 & $\begin{array}{l}\text { High Voltage } \\
\text { Resistance Standard }\end{array}$ & Spellman & $2000 \times 10^{6} \Omega$ & $0.02 \%$ \\
\hline RES8 & $\begin{array}{l}\text { Multifunction } \\
\text { Calibrator }\end{array}$ & Fluke & $1 \Omega$ to $100 \mathrm{M} \Omega$ & $15 \mathrm{ppm}$ to $100 \mathrm{ppm}$ \\
\hline RES9 & $\begin{array}{l}\text { High Precision } \\
\text { DMM }\end{array}$ & Hewlett-Packard & $10 \Omega$ to $100 \mathrm{M} \Omega$ & $25 \mathrm{ppm}$ to $500 \mathrm{ppm}$ \\
\hline
\end{tabular}

\section{AC Electrical Measurement}

\section{$\underline{\text { AC Voltage }}$}

AC voltage sources are calibrated using an alternating current measurement standard. The AC measurement standards are calibrated using a Fluke AC/DC Transfer Standards which is certified by the PSL.

Thermal voltage converter devices, including the AC/DC Transfer Standard, are certified for AC/DC difference by the PSL.

\section{$\underline{\text { AC Current }}$}

AC current sources are calibrated using FM\&T certified DC current sources and standard current shunts certified by the PSL. PSL certified AC resistors are used for currents less than or equal to $10 \mathrm{~mA}$. The current through these resistors is established by measuring the voltage drop across the standard resistor using an AC voltmeter and calculating the current using a direct relationship. 


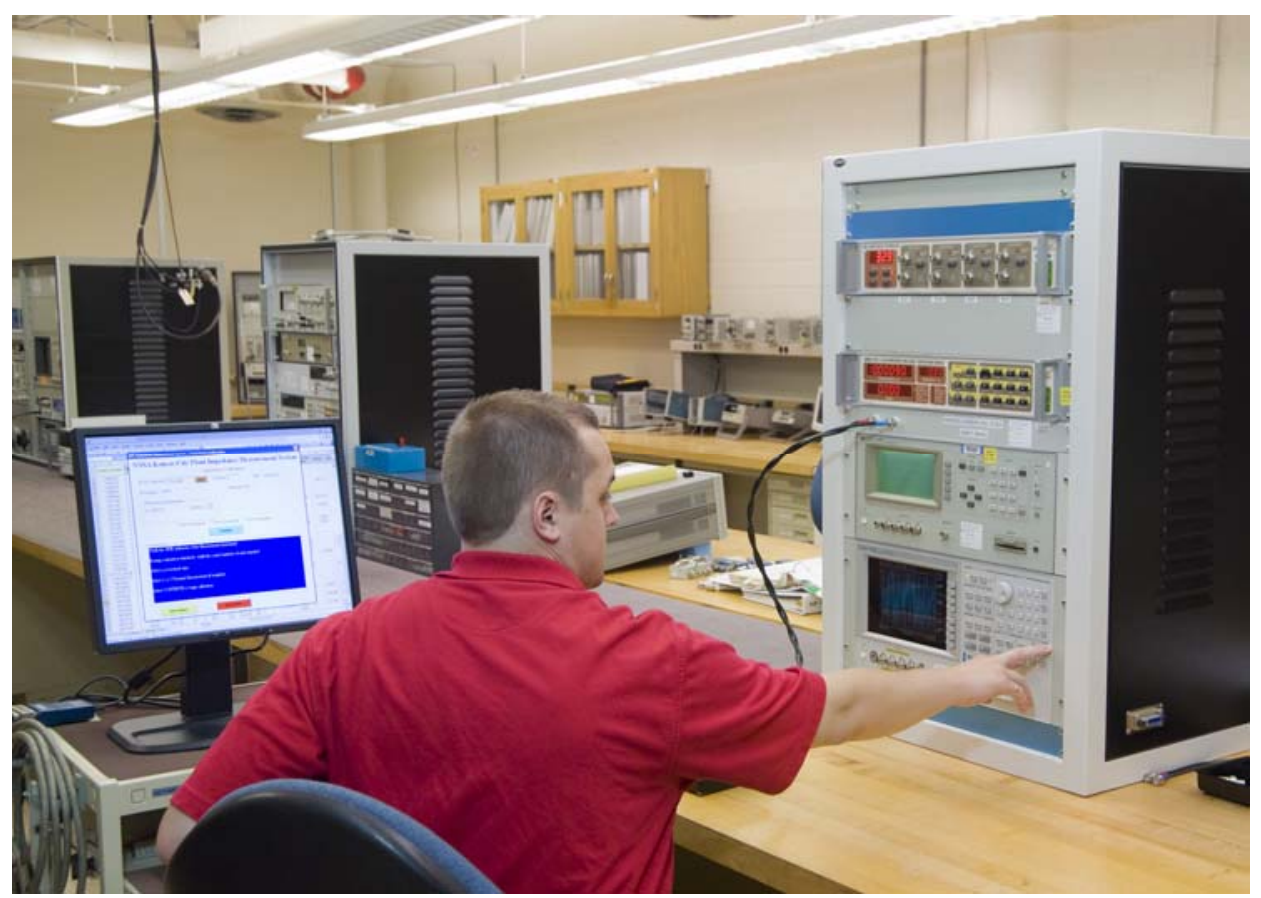

Impedance Calibration

\section{Capacitance and Inductance}

Calibration of capacitors and inductors is made either through direct measurement or through a direct comparison with a certified standard of similar value. All comparison inductors and some of the comparison capacitors are certified by the PSL. The remaining capacitors are certified inhouse using equipment identical to that used at the PSL.

Depending on the frequency and required uncertainty, capacitance measurements are completed on either the High-Precision Capacitance Meter, $1 \mathrm{kHz} / \mathrm{MHz}$ capacitance bridge or a Precision Impedance Analyzer. Inductance measurements are completed using the Precision Impedance Analyzer.

The measurement uncertainties for impedance vary with nominal value and frequency. Capacitance uncertainties may be as low as $\pm 10 \mathrm{ppm}$ and inductance uncertainties may reach \pm $0.03 \%$.

\section{Frequency and Time}

The frequency standard is established using one of two GPS receivers certified by the PSL. Each receiver is compared to the PSL primary frequency standard using the NIST Frequency and Analysis System. Frequency standards are used as references for standard counters and generators used for calibration. The comparator feature of the primary GPS receiver is used to certify rubidium frequency standards. 
A digital clock is synchronized with the time information transmitted through GPS and is referenced to Universal Coordinated Time (UTC-NIST).

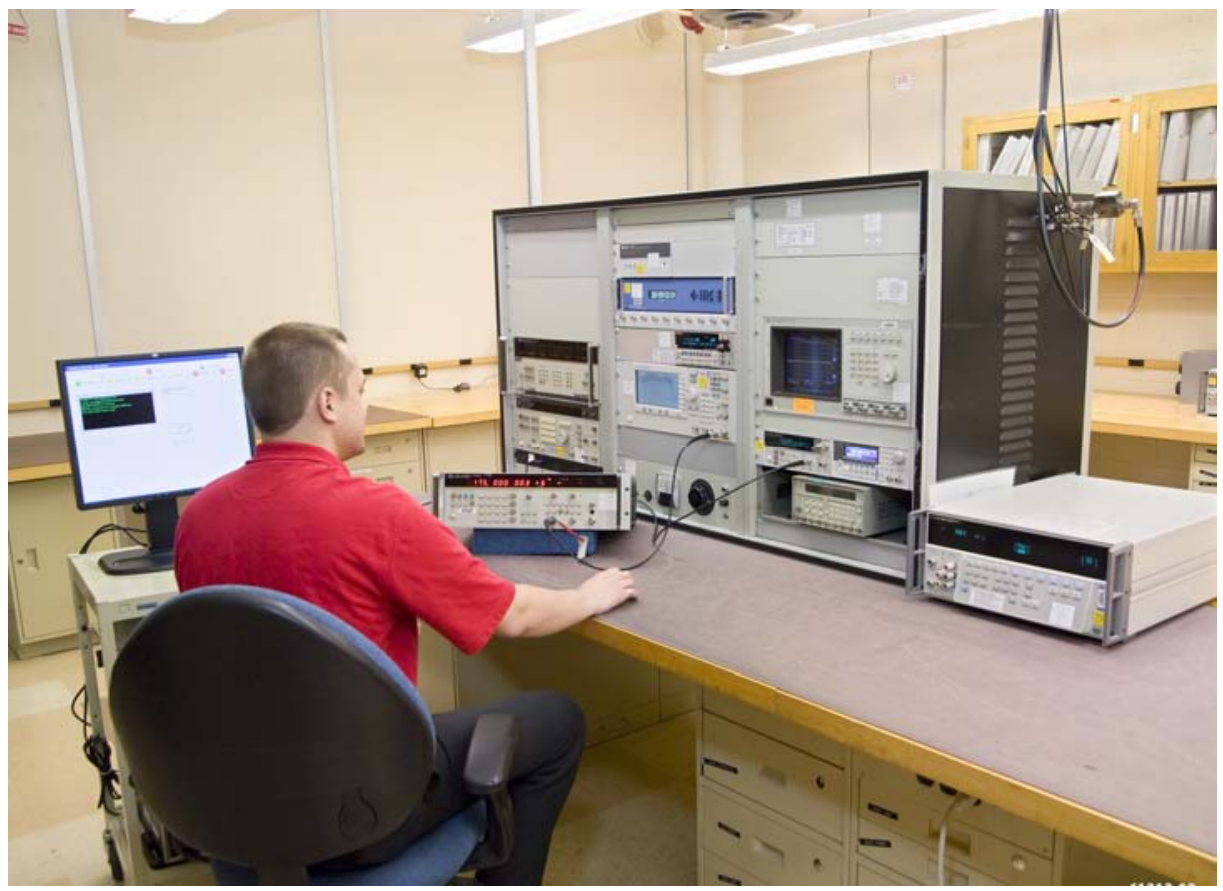

Computer-Controlled Counter Calibration 
AC Measurement Capability

\begin{tabular}{|c|c|c|c|}
\hline Type & Range & Frequency & Measuring Uncertainty $( \pm)(k=2)$ \\
\hline \multirow[t]{9}{*}{ AC Voltage * } & 2.2 to $70 \mathrm{mV}$ & $10 \mathrm{~Hz}$ to $100 \mathrm{kHz}$ & $<0.12 \%+2.5 \mathrm{~V}$ \\
\hline & 2.2 to $70 \mathrm{mV}$ & $100 \mathrm{kHz}$ to $1 \mathrm{MHz}$ & $<0.35 \%+8 \quad V$ \\
\hline & 70 to $700 \mathrm{mV}$ & $10 \mathrm{~Hz}$ to $100 \mathrm{kHz}$ & $<0.03 \%+2.5 \mathrm{~V}$ \\
\hline & 70 to $700 \mathrm{mV}$ & $100 \mathrm{kHz}$ to $1 \mathrm{MHz}$ & $<0.11 \%+8 \quad V$ \\
\hline & $700 \mathrm{mV}$ to $70 \mathrm{~V}$ & $10 \mathrm{~Hz}$ to $300 \mathrm{kHz}$ & $<200 \mathrm{ppm}$ \\
\hline & $700 \mathrm{mV}$ to $70 \mathrm{~V}$ & $300 \mathrm{kHz}$ to $1 \mathrm{MHz}$ & $<1200$ ppm \\
\hline & $70 \mathrm{~V}$ to $220 \mathrm{~V}$ & $10 \mathrm{~Hz}$ to $500 \mathrm{kHz}$ & $<500$ ppm \\
\hline & $220 \mathrm{~V}$ to $1000 \mathrm{~V}$ & $10 \mathrm{~Hz}$ to $100 \mathrm{kHz}$ & $<800 \mathrm{ppm}$ \\
\hline & 1 to $30 \mathrm{kV}$ & $60 \mathrm{~Hz}$ & $0.066 \%$ \\
\hline AC Current & $10 \mathrm{~mA}$ to $20 \mathrm{~A}$ & $10 \mathrm{~Hz}$ to $50 \mathrm{kHz}$ & 0.05 to $0.07 \%$ \\
\hline \multirow[t]{4}{*}{ Capacitance } & $0.001 \mathrm{pF}$ to $1 \mu \mathrm{F}$ & $1 \mathrm{kHz}$ & $(0.01 \%+0.00005 \mathrm{pF})$ \\
\hline & 1 to $10 \mu \mathrm{F}$ & $1 \mathrm{kHz}$ & $0.02 \%$ \\
\hline & 10 to $100 \mu \mathrm{F}$ & $1 \mathrm{kHz}$ & $0.5 \%$ \\
\hline & 1.0 to $1000 \mathrm{pF}$ & $1 \mathrm{MHz}$ & 0.1 to $0.2 \%$ \\
\hline \multirow[t]{3}{*}{ Inductance $* *$} & 0.05 to $2 \mu \mathrm{H}$ & $10 \mathrm{kHz}$ to $1 \mathrm{MHz}$ & $0.7 \%$ to $12 \%$ \\
\hline & 2 to $100 \mu \mathrm{H}$ & $10 \mathrm{kHz}$ to $\mathrm{MHz}$ & $0.7 \%$ to $3 \%$ \\
\hline & $100 \mu \mathrm{H}$ to $10 \mathrm{H}$ & $1 \mathrm{kHz}$ & $0.04 \%$ to $0.4 \%$ \\
\hline Frequency & $1 \mathrm{~Hz}$ to $18 \mathrm{GHz}$ & & $\pm 1.00 \times 10^{-12}$ \\
\hline Time of Day & & & $0.5 \mathrm{~ms}$ \\
\hline
\end{tabular}

* Accuracy depending on range and frequency

** Accuracy depending on inductance and frequency 


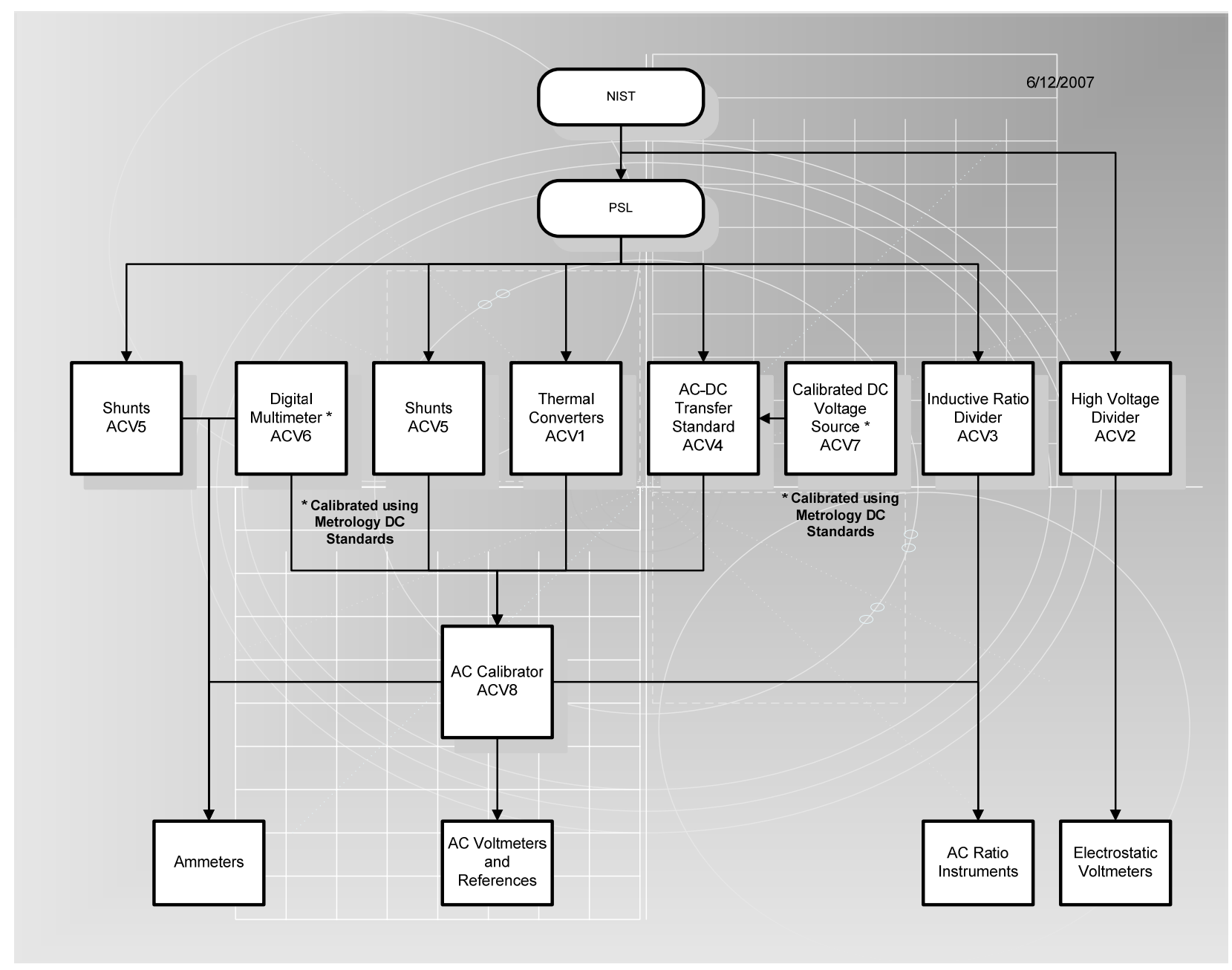

AC Current, Voltage, and Ratio Traceability

AC Current, Voltage, and Ratio Standards

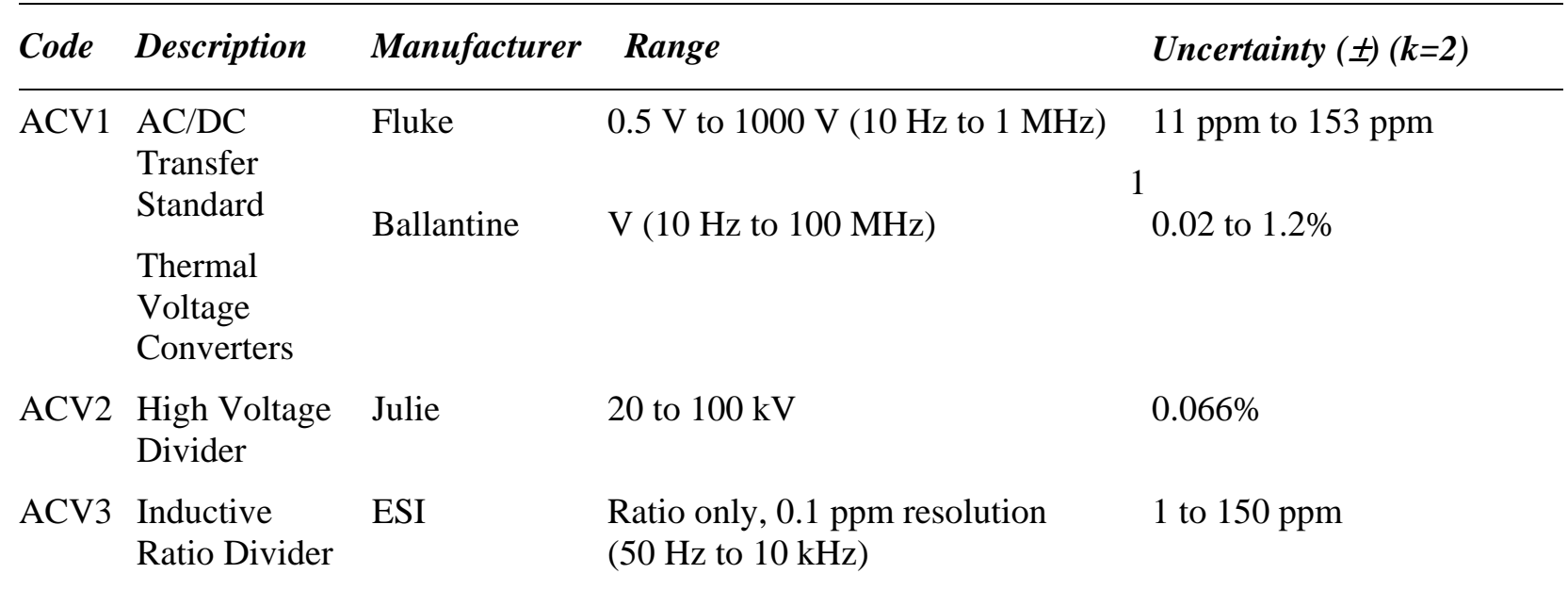




\section{AC Current, Voltage, and Ratio Standards}

\begin{tabular}{|c|c|c|c|c|}
\hline Code & Description & Manufacturer & Range & Uncertainty $( \pm)(k=2)$ \\
\hline \multirow[t]{9}{*}{ ACV4 } & \multirow{9}{*}{$\begin{array}{l}\text { AC } \\
\text { Measurement } \\
\text { Standard }\end{array}$} & \multirow[t]{9}{*}{ Fluke 5790A } & 2.2 to $70 \mathrm{mV}(10 \mathrm{~Hz}$ to $100 \mathrm{kHz})$ & $<0.12 \%+2.5 \quad \mathrm{~V}$ \\
\hline & & & 2.2 to $70 \mathrm{mV}(100 \mathrm{kHz}$ to $1 \mathrm{MHz})$ & $<0.35 \%+8 \quad \mathrm{~V}$ \\
\hline & & & 70 to $700 \mathrm{mV}$ (10 Hz to $100 \mathrm{kHz})$ & $<0.03 \%+2.5 \quad \mathrm{~V}$ \\
\hline & & & 70 to $700 \mathrm{mV}(100 \mathrm{kHz}$ to $1 \mathrm{MHz})$ & $<0.11 \%+8 \quad \mathrm{~V}$ \\
\hline & & & $700 \mathrm{mV}$ to $70 \mathrm{~V}(10 \mathrm{~Hz}$ to $300 \mathrm{kHz})$ & $<200$ ppm \\
\hline & & & $700 \mathrm{mV}$ to $70 \mathrm{~V}$ (300 kHz to $1 \mathrm{MHz}$ ) & $<1200 \mathrm{ppm}$ \\
\hline & & & $70 \mathrm{~V}$ to $220 \mathrm{~V}(10 \mathrm{~Hz}$ to $500 \mathrm{kHz})$ & $<500 \mathrm{ppm}$ \\
\hline & & & $220 \mathrm{~V}$ to $1000 \mathrm{~V}$ (10 Hz to $100 \mathrm{kHz})$ & $<800 \mathrm{ppm}$ \\
\hline & & & 1 to $30 \mathrm{kV}(60 \mathrm{~Hz})$ & $0.066 \%$ \\
\hline ACV5 & Shunts & Holt & $10 \mathrm{~mA}$ to $20 \mathrm{~A}(10 \mathrm{~Hz}$ to $50 \mathrm{kHz})$ & 0.05 to $0.07 \%$ \\
\hline \multirow[t]{3}{*}{ ACV6 } & \multirow{3}{*}{$\begin{array}{l}\text { Digital } \\
\text { Multimeter }\end{array}$} & \multirow{3}{*}{$\begin{array}{l}\text { Hewlett } \\
\text { Packard / } \\
\text { Agilent }\end{array}$} & $100 \mathrm{mV}$ range & $15 \mathrm{ppm}+10 \mathrm{ppm}$ of range \\
\hline & & & 1 to $100 \mathrm{~V}$ ranges & $10 \mathrm{ppm}+1 \mathrm{ppm}$ of range \\
\hline & & & $1000 \mathrm{~V}$ range & $20 \mathrm{ppm}+1 \mathrm{ppm}$ of range \\
\hline ACV7 & $\begin{array}{l}\text { Calibrated } \\
\text { DC Voltage } \\
\text { Source }\end{array}$ & Fluke & 10 to $1000 \mathrm{~V}$ three ranges & $<15$ ppm \\
\hline \multirow[t]{5}{*}{ ACV8 } & \multirow[t]{5}{*}{ AC Calibrator } & \multirow[t]{5}{*}{ Fluke } & $1 \mathrm{mV}$ to $100 \mathrm{mV}$ (10 Hz to $30 \mathrm{kHz}$ ) & $\begin{array}{l}0.02 \% \text { of setting } \\
+0.005 \% \mathrm{FS}+10 \mu \mathrm{V}\end{array}$ \\
\hline & & & $1 \mathrm{~V}$ to $100 \mathrm{~V}$ (10 Hz to $50 \mathrm{kHz})$ & $\begin{array}{l}0.02 \% \text { of setting } \\
+0.005 \% \text { FS }+10 \mu \mathrm{V}\end{array}$ \\
\hline & & & $\begin{array}{l}1 \mathrm{mV} \text { to } 100 \mathrm{mV} \text { (30 kHz to } 100 \\
\mathrm{kHz} \text { ) }\end{array}$ & $\begin{array}{l}0.06 \% \text { of setting } \\
+0.006 \% \text { FS }+10 \mu \mathrm{V}\end{array}$ \\
\hline & & & $1 \mathrm{~V}$ to $10 \mathrm{~V}(50 \mathrm{kHz}$ to $100 \mathrm{kHz})$ & $\begin{array}{l}0.06 \% \text { of setting } \\
+0.006 \% \mathrm{FS}+10 \mu \mathrm{V}\end{array}$ \\
\hline & & & $1000 \mathrm{~V}$ range (50 Hz to $1 \mathrm{kHz}$ ) & $\begin{array}{l}0.06 \% \text { of setting } \\
+0.006 \% \text { FS }+10 \mu \mathrm{V}\end{array}$ \\
\hline
\end{tabular}


AC Current, Voltage, and Ratio Standards

\begin{tabular}{|c|c|c|c|c|}
\hline Code & Description & Manufacturer & Range & Uncertainty $( \pm)(k=2)$ \\
\hline & & & $1 \mathrm{mV}$ to $100 \mathrm{mV}$ (100 kHz to 1 & $0.6 \%$ of setting $+0.1 \% \mathrm{FS}$ \\
\hline & & & $\mathrm{MHz})$ & $0.4 \%$ of setting $+0.1 \%$ FS \\
\hline & & & $1 \mathrm{~V}$ to $10 \mathrm{~V}(100 \mathrm{kHz}$ to $1 \mathrm{MHz})$ & $0.1 \%$ of setting \\
\hline & & & $100 \mathrm{~V}$ range (50 kHz to $100 \mathrm{kHz}$ ) & \\
\hline & & & Wideband output & $0.3 \%$ \\
\hline & & & 10 to $30 \mathrm{~Hz}$ & $0.25 \%$ \\
\hline & & & $>30 \mathrm{~Hz}$ to $1 \mathrm{MHz}$ & $0.75 \%$ \\
\hline & & & $>1 \mathrm{MHz}$ to $20 \mathrm{MHz}$ & $1.0 \%$ \\
\hline & & & $>20 \mathrm{MHz}$ to $30 \mathrm{MHz}$ & $0.07 \%$ of setting $+0.01 \%$ of \\
\hline & & & to $2 \mathrm{~A}$ & range \\
\hline
\end{tabular}

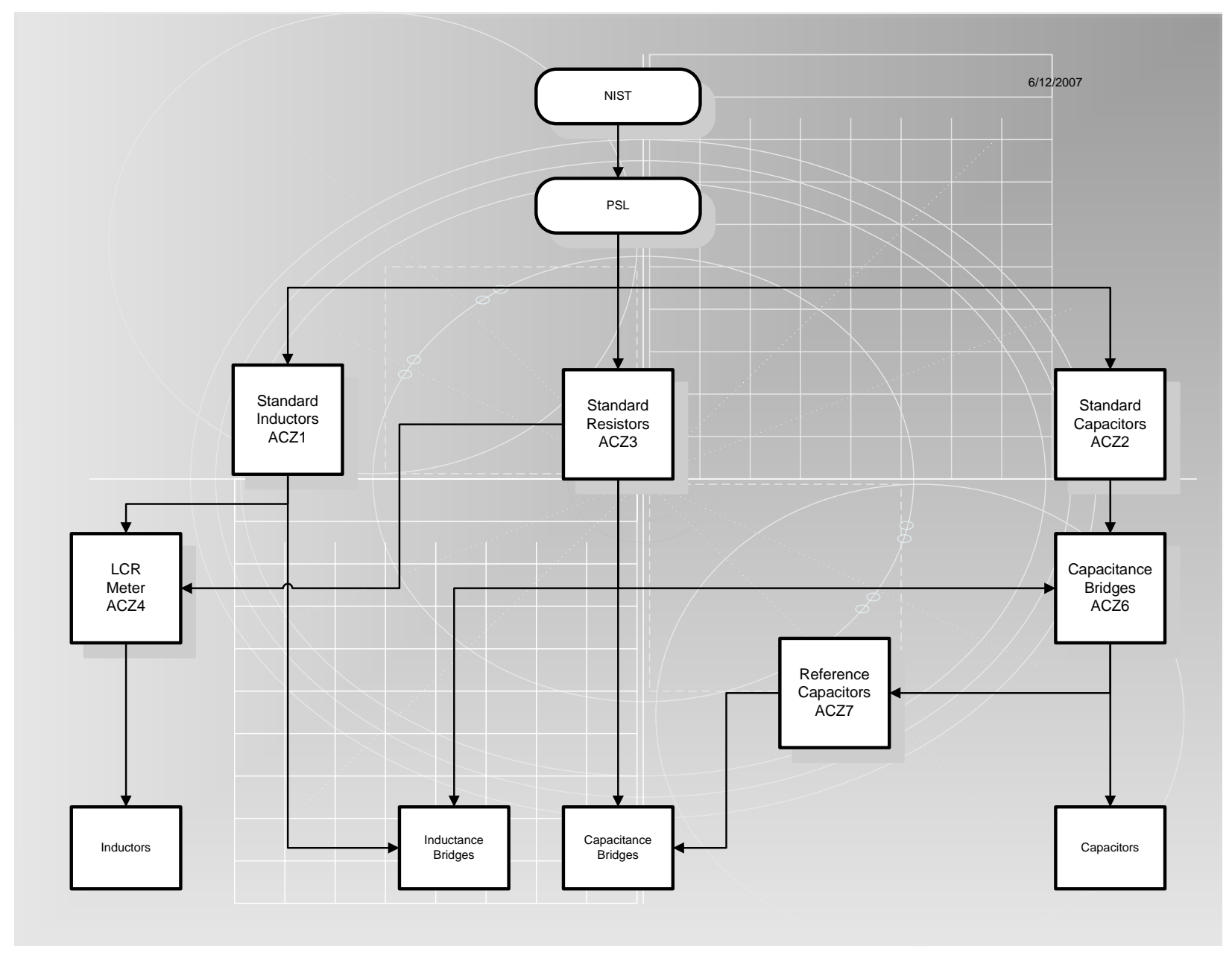

Inductance and Capacitance Traceability 
Inductance, Capacitance, and AC Resistance Standards

\begin{tabular}{|c|c|c|c|c|}
\hline Code & Description & Manufacturer & Range & Uncertainty $( \pm)(k=2)$ \\
\hline ACZ1 & Standard Inductors & $\begin{array}{l}\text { General Radio, } \\
\text { FM\&T Metrology, } \\
\text { Hewlett-Packard, } \\
\text { Boonton }\end{array}$ & $\begin{array}{l}50 \mu \mathrm{H} \text { to } 10 \mathrm{H} \\
50 \mathrm{nH} \text { to } 100 \mu \mathrm{H}\end{array}$ & $\begin{array}{l}0.03 \text { to } 0.3 \% * \\
0.3 \text { to } 10 \% *\end{array}$ \\
\hline ACZ2 & Standard Capacitors & $\begin{array}{l}\text { General Radio } \\
\text { Andeen-Hagerling }\end{array}$ & $\begin{array}{l}1000 \mathrm{pF} \text {, fixed } \\
10 \mathrm{pF}, 20 \mathrm{pF}, 40 \mathrm{pF}, 50 \mathrm{pF}\end{array}$ & $\begin{array}{l}0.003 \% \text { at } 1 \mathrm{kHz} \\
< \pm 9 \mathrm{ppm}\end{array}$ \\
\hline ACZ3 & Standard Resistors & $\begin{array}{l}\text { Leeds \& Northrup } \\
\text { Hewlett-Packard }\end{array}$ & $\begin{array}{l}1 \text { to } 20 \mathrm{k} \Omega \\
0.1 \text { to } 100 \mathrm{k} \Omega\end{array}$ & $\begin{array}{l}0.015 \% \\
0.5 \% * * *\end{array}$ \\
\hline ACZ4 & LCR Meter & $\begin{array}{l}\text { Hewlett-Packard / } \\
\text { Agilent }\end{array}$ & $\begin{array}{l}100 \mu \mathrm{H} \text { to } 5 \mathrm{H} \\
0.05 \mu \mathrm{H} \text { to } 10 \mu \mathrm{H}\end{array}$ & $\begin{array}{l}0.10 \text { to } 0.3 \% \\
\text { (direct measurement) } \\
0.1 \text { to } 10 \% \text { (comparison to } \\
\text { standard inductors) }\end{array}$ \\
\hline ACZ6 & Capacitance Bridge & Hewlett-Packard & $\begin{array}{l}10 \mathrm{pF} \text { to } 1 \mathrm{nF}(160 \mathrm{~Hz} \text { to } 10 \\
\mathrm{kHz}) \\
10 \mathrm{pF} \text { to } 1 \mathrm{nF}(100 \mathrm{~Hz} \text { to } 10 \\
\mathrm{kHz}) \\
0.1 \mathrm{pF} \text { to } 1 \mathrm{nF}(1 \mathrm{kHz}) \\
1 \mu \mathrm{F} \text { to } 10 \mu \mathrm{F} \\
0.1 \text { to } 1000 \mathrm{pF}\end{array}$ & $\begin{array}{l}10 \mathrm{ppm} \\
\pm 10 \mathrm{ppm} \\
\pm 10 \mathrm{ppm} \\
0.1 \% \text { at } 1 \mathrm{kHz} \\
0.2 \% \text { at } 1 \mathrm{MHz}\end{array}$ \\
\hline ACZ7 & Reference Capacitors & $\begin{array}{l}\text { sBoonton Electric } \\
\text { General Radio } \\
\text { FM\&T Metrology }\end{array}$ & $\begin{array}{l}1 \text { to } 1000 \mathrm{pF} \\
0.1 \text { to } 1000 \mathrm{pF} \\
0.001 \text { to } 1 \mu \mathrm{F} \\
1 \text { to } 10 \mu \mathrm{F} \text { in } \\
1 \mu \mathrm{F} \text { increments } \\
10 \text { to } 100 \mu \mathrm{F} \text { in } \\
10 \mu \mathrm{F} \text { increments }\end{array}$ & $\begin{array}{l}0.02 \% \text { to } 0.11 \%{ }^{* *} \\
0.1 \text { to } 0.15 \%{ }^{* *} \\
0.02 \% \text { at } 1 \mathrm{kHz} \\
0.1 \% \text { at } 1 \mathrm{kHz} \\
0.1 \% \text { at } 1 \mathrm{kHz}\end{array}$ \\
\hline
\end{tabular}

* Uncertainty depending on inductance value and frequency

** Uncertainty depending on capacitance value and frequency

*** Uncertainty depending on resistance value and frequency 


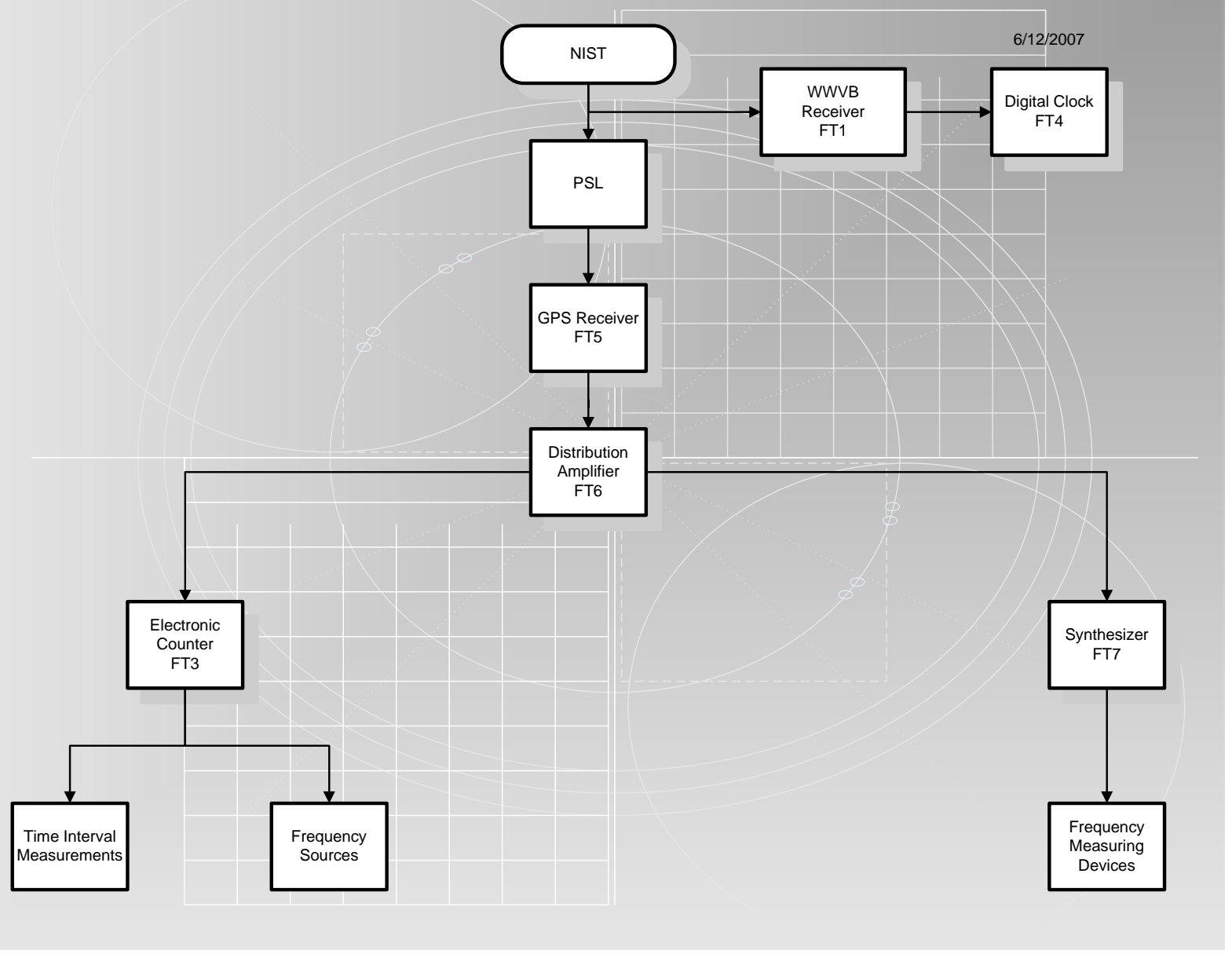

Frequency and Time Traceability

\section{Frequency and Time Standards}

\begin{tabular}{lllll}
\hline Code & Description & Manufacturer & Range & Uncertainty ( \pm ) (k=2) \\
\hline FT3 & Counter & Various & to $46 \mathrm{GHz}$ & Used with GPS \\
FT4 & Digital Clock & Symmetricom & 24 hours & $0.5 \mathrm{~s}$ \\
FT5 & GPS Receiver & Hewlett Packard & $10 \mathrm{MHz}, 1 \mathrm{pps}$ & 5 parts in $10^{12}$ \\
FT8 & GPS Receiver & Symmetricom & $10 \mathrm{MHz}, 1 \mathrm{pps}$ & $\pm 1.00 \times 10^{-12}$ \\
\hline
\end{tabular}




\section{RF/Microwave Measurements}

\section{$\underline{\text { Air Lines }}$}

Air line impedance standards are calibrated using dimensional measurement techniques. The inner and outer conductors' diameters are measured using air gages, and the lengths are measured using a length measurement system by comparison to gage blocks of similar lengths. The dimensional measurements are used to calculate the impedance and electrical length.

\section{$\underline{\text { Attenuators and Terminations }}$}

Standard attenuators and terminations are calibrated by NIST or the PSL and certified for calibrating Attenuation and Network Analyzer systems and to transfer their values by comparison to other attenuators and terminations.

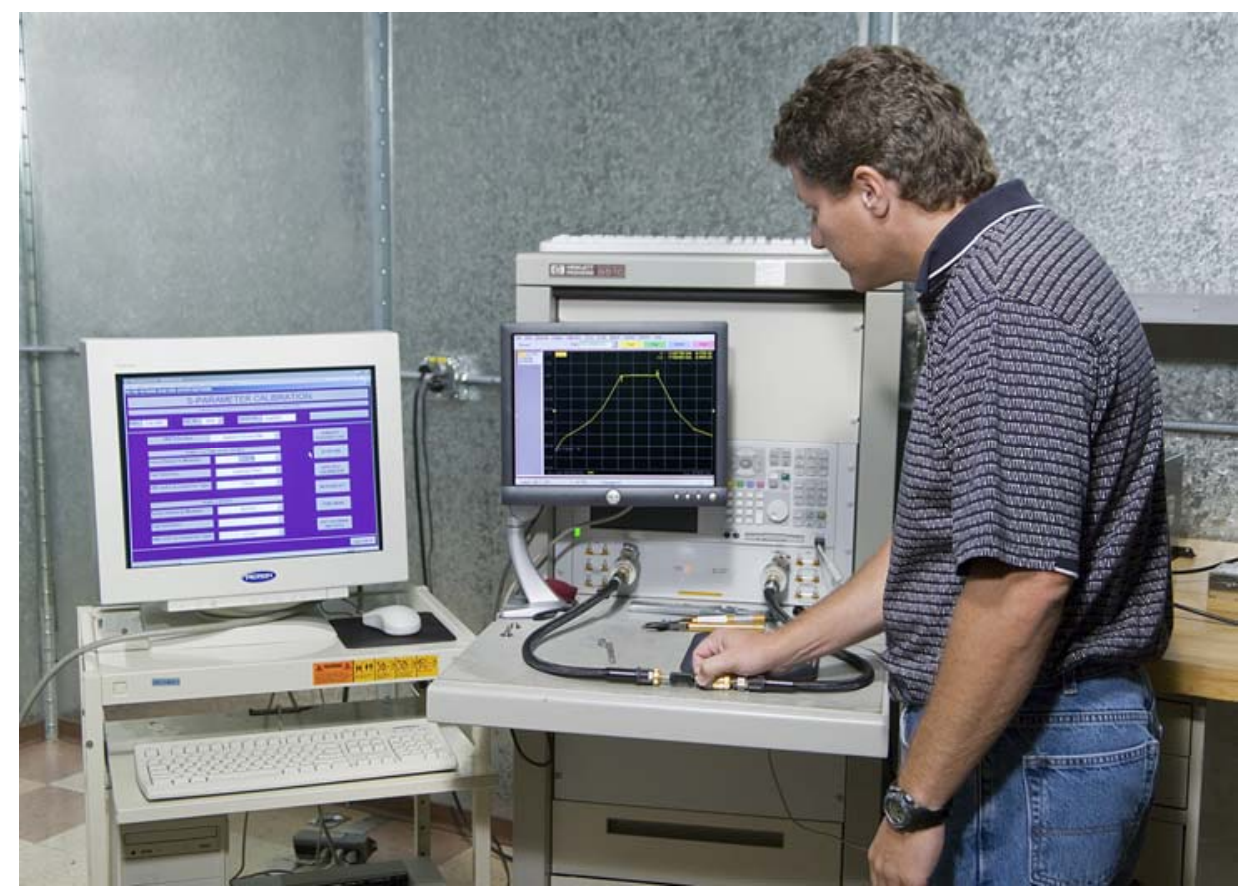

Attenuator Calibration Using an Automatic Network Analyzer

\section{Network Analyzers and Attenuation Systems}

Network analyzers and attenuation systems are calibrated over their operating range by air lines and NIST-calibrated terminations and attenuators. They are used to calibrate single and multiport devices for s-parameter measurements.

\section{$\underline{\text { Noise Source }}$}

Standard noise sources are calibrated for excess noise ratio (ENR) across a frequency range at the PSL. They are used to transfer the ENR values by comparison to other noise sources. 


\section{Thermistor Mounts}

Standard thermistor mounts are calibrated by PSL and certified for calibrating a Power Meter/Sensor Calibration system and transferring the calibration factor values by comparison to other thermistor mounts.

\section{Power System}

The power system is calibrated by transferring the calibration factors from PSL calibrated thermistor mounts to the systems reference sensor. The power system is used to calibrate power meters, sensors, and thermistor mounts.

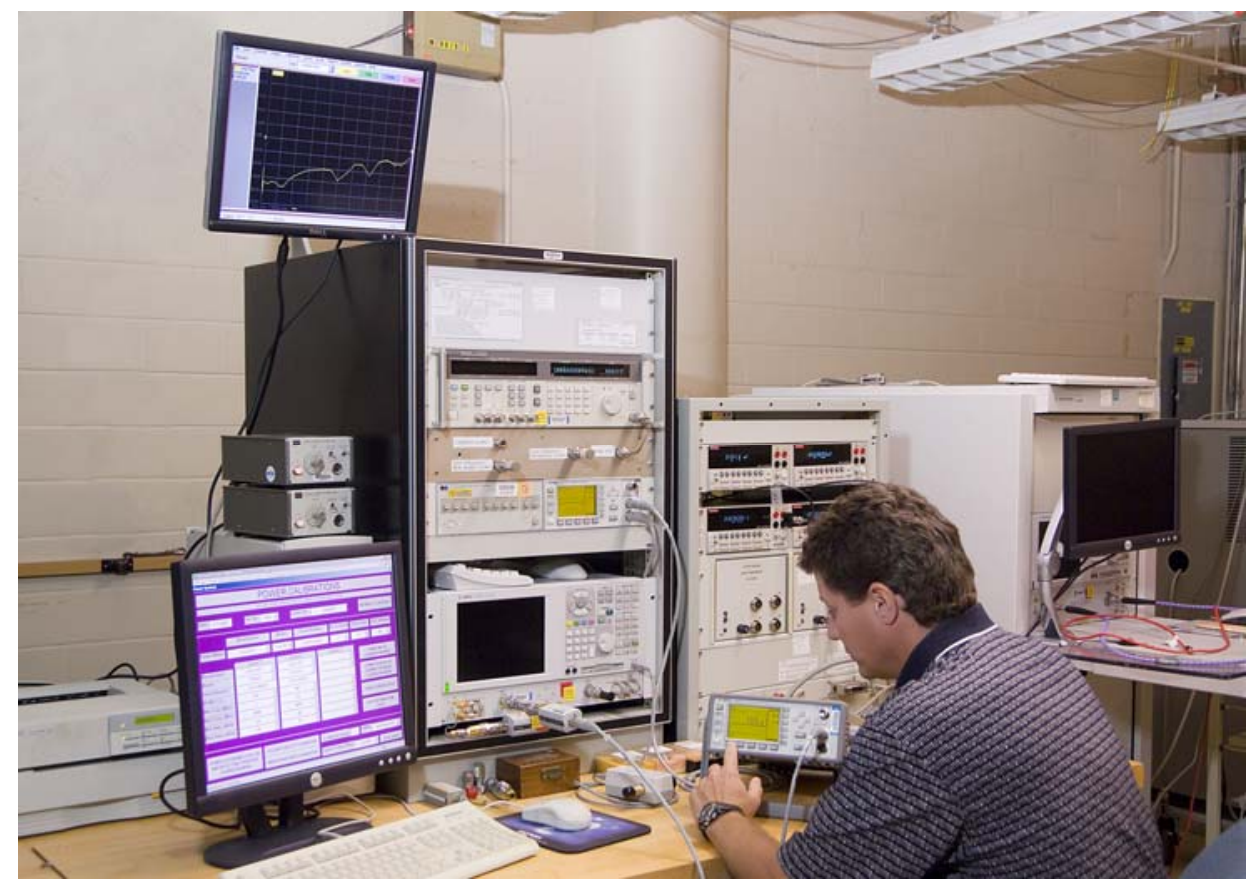

Power Meter Calibration 
Electrical Radio Frequency/Microwave Measurement Capability

\begin{tabular}{|c|c|c|c|}
\hline Type & Range & Frequency & $\begin{array}{l}\text { Measuring Uncertainty } \\
( \pm)(k=2)\end{array}$ \\
\hline \multirow{4}{*}{$\begin{array}{l}\text { Air Lines (Air- } \\
\text { Dielectric) }\end{array}$} & Impedance & $50 \mathrm{MHz}$ to $50 \mathrm{GHz}$ & $0.028 \Omega$ to $0.22 \Omega$ \\
\hline & $\begin{array}{l}\text { Electrical Length (3 to } 30 \\
\mathrm{~cm} \text { ) }\end{array}$ & $50 \mathrm{MHz}$ to $50 \mathrm{GHz}$ & $0.0017 \mathrm{~cm}$ to $0.042 \mathrm{~cm}$ \\
\hline & Diameter (0.10 to 1.5$) \mathrm{cm}$ & & $(00010$ to 00026$) \mathrm{cm}$ \\
\hline & $\begin{array}{l}\text { Physical Length (3 to 30) } \\
\text { cm }\end{array}$ & & \\
\hline \multicolumn{4}{|l|}{ Scattering Parameters ${ }^{1}$} \\
\hline \multirow[t]{2}{*}{ | | } & $\left|\mathrm{S}_{\mathrm{ii}}\right|, 0$ to 1 & $300 \mathrm{kHz}$ to $26.5 \mathrm{GHz}$ & 0.003 to 0.045 \\
\hline & $\left|\mathrm{S}_{\mathrm{ii}}\right|, 0$ to 1 & $>26.5 \mathrm{GHz}$ to $50 \mathrm{GHz}$ & 0.035 to 0.065 \\
\hline \multirow[t]{2}{*}{ Phase } & $\operatorname{Arg}\left(\mathrm{S}_{\mathrm{ii}}\right),-180^{\circ}$ to $180^{\circ}$ & $300 \mathrm{kHz}$ to $26.5 \mathrm{GHz}$ & $0.35^{\circ}$ to $180^{\circ}$ \\
\hline & $\operatorname{Arg}\left(S_{\mathrm{ii}}\right),-180^{\circ}$ to $180^{\circ}$ & $>26.5 \mathrm{GHz}$ to $50 \mathrm{GHz}$ & $4.0^{\circ}$ to $180^{\circ}$ \\
\hline \multirow[t]{3}{*}{ Attenuation } & $\left|\mathrm{S}_{\mathrm{ij}}\right|, 0 \mathrm{~dB}$ to $110 \mathrm{~dB}$ & $300 \mathrm{kHz}$ to $18 \mathrm{GHz}$ & $0.01 \mathrm{~dB}$ to $1.5 \mathrm{~dB}$ \\
\hline & $\left|\mathrm{S}_{\mathrm{ij}}\right|, 0 \mathrm{~dB}$ to $80 \mathrm{~dB}$ & $>18 \mathrm{GHz}$ to $26.5 \mathrm{GHz}$ & $0.07 \mathrm{~dB}$ to $1.5 \mathrm{~dB}$ \\
\hline & $\left|\mathrm{S}_{\mathrm{ij}}\right|, 0 \mathrm{~dB}$ to $70 \mathrm{~dB}$ & $>26.5 \mathrm{GHz}$ to $50 \mathrm{GHz}$ & Capability \\
\hline Transmission Phase & $\operatorname{Arg}\left(\mathrm{S}_{\mathrm{ij}}\right), 0 \mathrm{~dB}$ to $70 \mathrm{~dB}$ & $300 \mathrm{kHz}$ to $50 \mathrm{GHz}$ & Capability \\
\hline Thermistor Mounts $^{1}$ & $\begin{array}{l}\text { Calibration Factor ( } 0.9 \text { to } \\
1.0 \text { ) }\end{array}$ & $1 \mathrm{MHz}$ to $18 \mathrm{GHz}$ & $0.5 \%$ to $3 \%$ \\
\hline $\begin{array}{l}\text { CW Power Meter } \\
\text { Systems }^{1}\end{array}$ & $1 \mathrm{nW}$ to $100 \mathrm{~mW}$ & $100 \mathrm{kHz}$ to $18 \mathrm{GHz}$ & $2.4 \%$ to $5.7 \%$ \\
\hline $\begin{array}{l}\text { Peak Power Meter } \\
\text { Systems }^{1}\end{array}$ & $10 \mu \mathrm{W}$ to $100 \mathrm{~mW}$ & $1 \mathrm{GHz}$ to $2 \mathrm{GHz}$ & $7 \%$ \\
\hline Group Delay ${ }^{1}$ & $1 \mathrm{~ns}$ to $1200 \mathrm{~ns}$ & $50 \mathrm{MHz}$ to $2.0 \mathrm{GHz}$ & $0.005 \mathrm{~ns}$ to $0.5 \mathrm{~ns}$ \\
\hline Noise Sources $^{1}$ & $\mathrm{ENR} \sim 15 \mathrm{~dB}$ & $60 \mathrm{MHz}$ to $3.55 \mathrm{GHz}$ & $0.1 \mathrm{~dB}$ to 0.35 \\
\hline
\end{tabular}

${ }^{1}$ Referenced to $50 \Omega+$ j0 $\Omega$. 


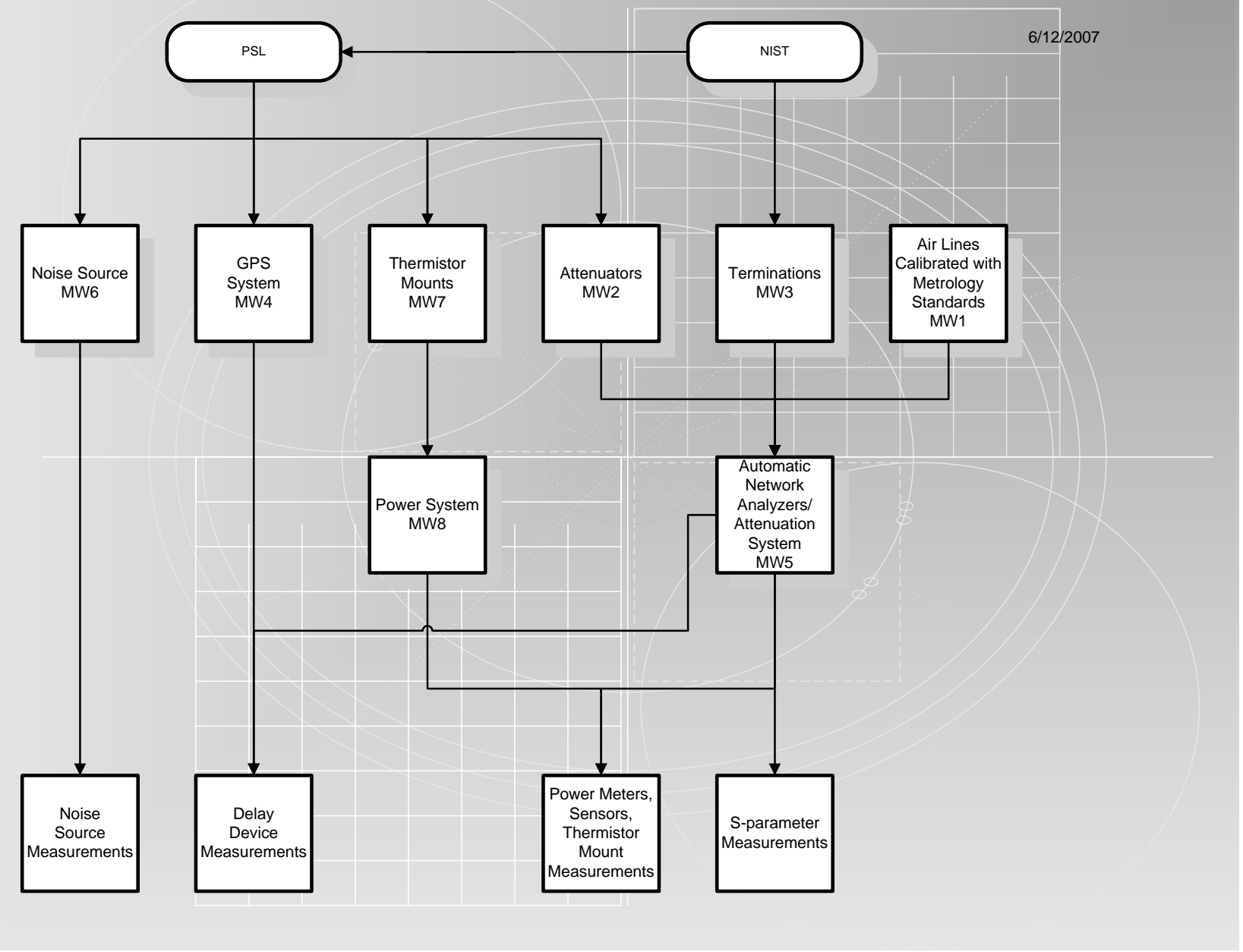

Radio Frequency and Microwave Traceability 


\section{Radio Frequency and Microwave Standards}

\begin{tabular}{|c|c|c|c|c|}
\hline Code & Description & Manufacturer & Range & Uncertainty $(k=2)$ \\
\hline \multirow[t]{4}{*}{ MW1 } & Air Lines & General Radio & $3.5 \mathrm{~mm}, 7 \mathrm{~mm}, 14 \mathrm{~mm}$, and & $|\mathrm{Z}| \pm 0.028$ to 0.22 \\
\hline & & & Diameter (0.10 to 1.5$) \mathrm{cm}$ & $\pm 0.00013 \mathrm{~cm}$ to $0.00045 \mathrm{~cm}$ \\
\hline & & & $\begin{array}{l}\text { Physical length (3 to 30) } \\
\text { cm }\end{array}$ & $\pm 0.0010 \mathrm{~cm}$ to $0.0026 \mathrm{~cm}$ \\
\hline & & Maury Microwave & $50 \mathrm{MHz}$ to $26.5 \mathrm{GHz}$ & $\begin{array}{l}\text { E.L. } \pm 0.0017 \mathrm{~cm} \text { to } 0.042 \\
\mathrm{~cm}\end{array}$ \\
\hline MW2 & Attenuators & Hewlett Packard & $\begin{array}{l}10 \mathrm{~dB}, 300 \mathrm{kHz} \text { to } \\
26.5 \mathrm{GHz}\end{array}$ & $\pm 0.008 \mathrm{~dB}$ to $0.042 \mathrm{~dB}$ \\
\hline MW3 & Terminations & $\begin{array}{l}\text { General Radio } \\
\text { Wiltron }\end{array}$ & $300 \mathrm{kHz}$ to $100 \mathrm{MHz}$ & $\begin{array}{l}\mid \pm 0.0008 \text { to } 0.003 \\
\quad \pm 0.2^{\circ} \text { to } 180^{\circ}\end{array}$ \\
\hline MW4 & $\begin{array}{l}\text { GPS } \\
\text { Receiver }\end{array}$ & Hewlett Packard & $10 \mathrm{MHz}$ & $\pm 0.000005 \mathrm{ppm}$ \\
\hline \multirow[t]{3}{*}{ MW5 } & $\begin{array}{l}\text { Network } \\
\text { Analyzers }\end{array}$ & Hewlett Packard & $300 \mathrm{kHz}$ to $50 \mathrm{GHz}$ & | $\mid \pm 0.001$ to 0.065 \\
\hline & & & $\begin{array}{l}\mid, 0 \text { to } 1 ; \\
,-180^{\circ} \text { to } 180^{\circ}\end{array}$ & $\pm 0.35^{\circ}$ to $180^{\circ}$ \\
\hline & & & $\begin{array}{l}\text { Attenuation: } 0 \text { to } 110 \mathrm{~dB} \\
300 \mathrm{kHz} \text { to } 26.5 \mathrm{GHz}\end{array}$ & \pm 0.01 to $1.5 \mathrm{~dB}$ \\
\hline MW6 & Noise Source & Hewlett Packard & $60 \mathrm{MHz}$ to $3.55 \mathrm{GHz}$ & \pm 0.1 to $0.35 \mathrm{~dB}$ \\
\hline MW7 & $\begin{array}{l}\text { Thermistor } \\
\text { Mounts }\end{array}$ & Hewlett Packard & $1 \mathrm{MHz}$ to $18 \mathrm{GHz}$ & $\pm 0.3 \%$ to $1.5 \%$ \\
\hline MW8 & $\begin{array}{l}\text { Power } \\
\text { System }\end{array}$ & FM\&T Metrology & $1 \mathrm{MHz}$ to $18 \mathrm{GHz}$ & $\pm 1.0 \%$ to $2.5 \%$ \\
\hline
\end{tabular}




\section{Optical and Radiation}

\section{Optical Radiometric Measurement}

Radiometry is the measurement of radiation in the optical spectrum, which includes ultraviolet, visible, and infrared light. The main radiometric reference standards at FM\&T are heat-flow calorimeters and wavelength standards, which include Helium-Neon (HeNe) lasers and Mercury spectral lamps. The PSL calibrates the heat flow calorimeters. The HeNe laser wavelength standard is calibrated by NIST because of its low uncertainty. The mercury spectral lamps do not require calibration because of their physical characteristics. Measurements performed include incoherent measurement in the ultraviolet and visible regions of the optical spectrum and coherent measurements, which consist of HeNe, $\mathrm{Nd}$ :YAG, and $\mathrm{CO}_{2}$ lasers. Power levels of these measurements range from fractions of a microwatt to levels in excess of 1000 watts over wavelengths of $365 \mathrm{~nm}$ to $10.6 \mathrm{~m}$. Most of the radiometric calibration activity at FM\&T is calibrating Nd:YAG laser power sensors and meters in CW mode.

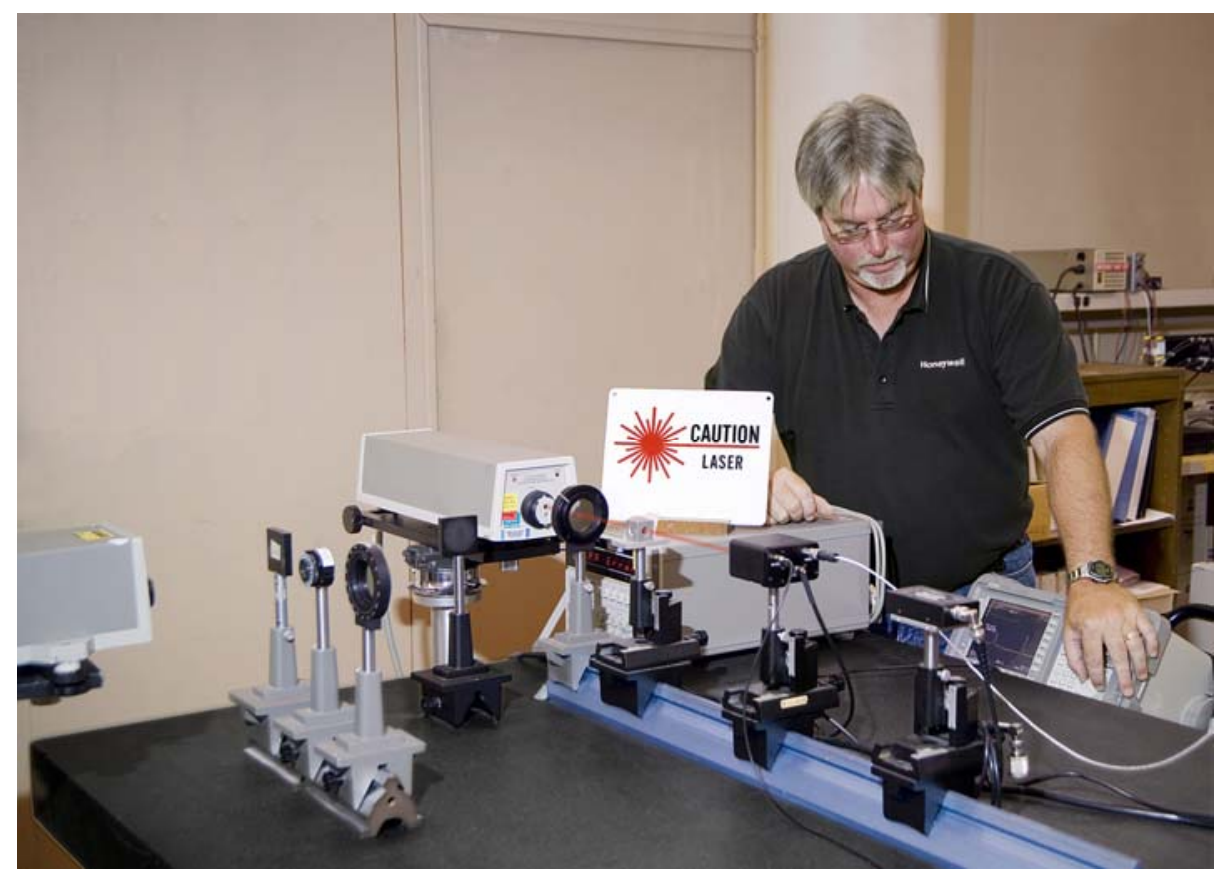

Laser Wavelength Calibration

\section{Optical Photometric Measurement}

Photometry is the measurement of visible light intensity and energy as it affects the human eye. The photometric reference standards at FM\&T are standard photometers, calibrated by NIST. Standard photometers output current and are used with a digital picoammeter to measure illuminance in units of foot-candles or lux. 


\section{Optical Measurement Capability}

\begin{tabular}{|c|c|c|}
\hline Type & Range & Measuring Uncertainty $( \pm)(k=2)$ \\
\hline \multirow[t]{2}{*}{ Laser Power } & $\lambda=1064 \mathrm{~nm}, 0.2$ to $10 \mathrm{~W}$ & $1.0 \%$ \\
\hline & $\lambda=1064 \mathrm{~nm}, 1$ to $25 \mathrm{~W}$ & $3.0 \%$ \\
\hline Laser Energy (Average) & $\lambda=1064 \mathrm{~nm}, 2 \mathrm{~mJ}$ to $20 \mathrm{~J}$ & $1.0 \%$ \\
\hline UV Irradiance & $\lambda=365 \mathrm{~nm}, 0$ to $2 \mathrm{~mW} / \mathrm{cm}^{2}$ & $3.0 \%$ \\
\hline UV Energy Density & $\lambda=365 \mathrm{~nm}, 0$ to $120 \mathrm{~mJ} / \mathrm{cm}^{2}$ & $3.0 \%$ \\
\hline Photo detector Responsivity & $\lambda=570$ to $910 \mathrm{~nm}$ & $1.0 \%$ \\
\hline Ultraviolet Irradiance & $\begin{array}{c}\lambda=365 \mathrm{~nm} \text { to } 1100 \mathrm{~nm} \\
0.1 \text { to } 10 \mathrm{~mW} / \mathrm{cm}^{2}\end{array}$ & $3.0 \%$ \\
\hline Laser Measuring System & $\lambda=632.8 \mathrm{~nm}(\mathrm{HeNe})$ & $\begin{array}{l}\text { (Distance) } 1.8 \text { ppm of displayed value } \\
+1 \text { count }\end{array}$ \\
\hline X-Ray Film Density & 0 to 4 Optical Density Units & ( 0.03 density units $+1 \%$ of reading) \\
\hline HeNe Laser Wavelength & $632.991370 \mathrm{~nm}$ & $0.027 \mathrm{ppm}$ \\
\hline Illuminance & 1 to 800 foot-candles & $2.3 \%$ \\
\hline
\end{tabular}




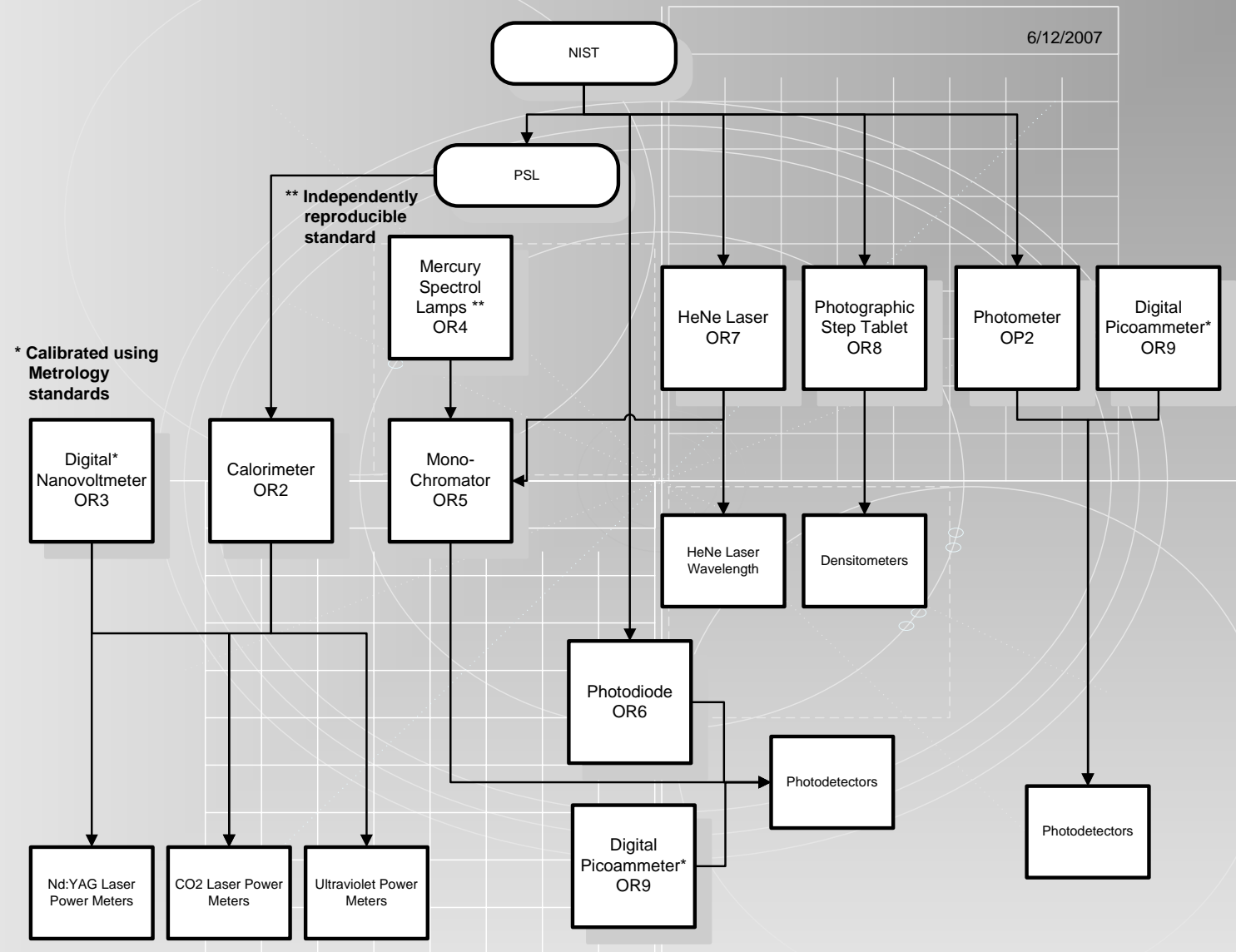

Optical Traceability (Radiometric) 


\section{Optical Radiometric Measurement Standards}

\begin{tabular}{|c|c|c|c|c|}
\hline Code & Description & Manufacturer & Range & Uncertainty $( \pm)(k=2)$ \\
\hline OR2 & Calorimeter & Scientech & $\begin{array}{l}1 \mathrm{~mW} \text { to } 10 \mathrm{~W} \\
365 \mathrm{~nm} \text { to } 1100 \mathrm{~nm} \\
10.6 \mu \mathrm{m}\end{array}$ & $\begin{array}{l}1.0 \% \\
2.7 \%\end{array}$ \\
\hline OR3 & $\begin{array}{l}\text { Digital } \\
\text { Nanovoltmeter }\end{array}$ & Keithley & $10 \mathrm{mV}$ to $10 \mathrm{~V}$ & ( $0.01 \%$ of reading $+4 \mathrm{ppm}$ of range) \\
\hline OR4 & $\begin{array}{l}\text { Mercury Spectral } \\
\text { Lamp }\end{array}$ & Oriel & 237.8 to $1092.2 \mathrm{~nm}$ & $0.1 \mathrm{~nm}$ \\
\hline OR5 & Monochromator & Various & 235 to $1092.2 \mathrm{~nm}$ & $1.0 \mathrm{~nm}$ \\
\hline OR6 & Photodiode & Hamamatsu & 400 to $910 \mathrm{~nm}$ & $0.45 \%$ to $0.28 \%$ \\
\hline OR7 & HeNe Laser & Hewlett Packard & $632.991370 \mathrm{~nm}$ & $11 \mathrm{ppb}$ \\
\hline OR8 & $\begin{array}{l}\text { Photographic Step } \\
\text { Tablet }\end{array}$ & NIST & 0 to 4 density units & 0.0075 Optical density units \\
\hline OR9 & Digital Picoammeter & Keithley & $200 \mathrm{nA}$ to $20 \mathrm{~mA}$ & $\begin{array}{l}(0.2 \% \text { of reading }+10 \text { digits }) \text { to }(0.1 \% \\
\text { of reading }+10 \text { digits })\end{array}$ \\
\hline $\mathrm{OP} 2$ & Standard Photometer & Graseby & $\begin{array}{l}1 \text { to } 800 \text { foot- } \\
\text { candles }\end{array}$ & $1.7 \%$ \\
\hline
\end{tabular}

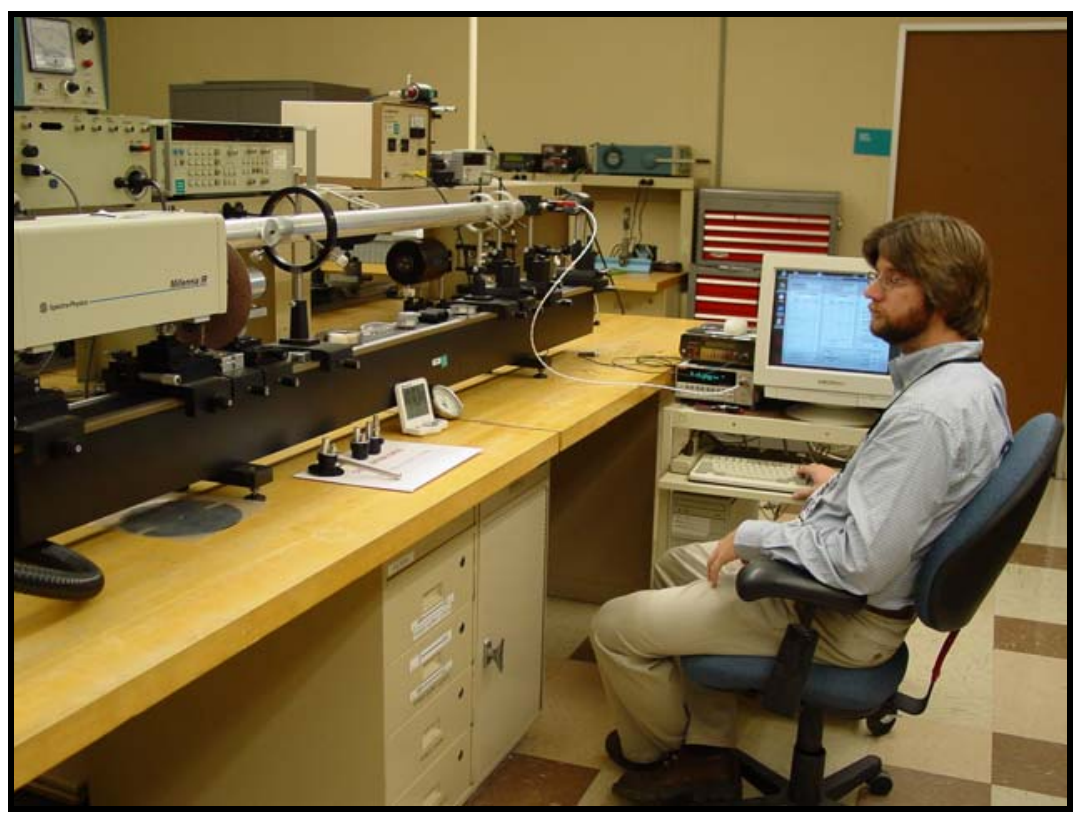

Nd:YAG Laser Power Meter Calibration 